Historic, Archive Document

Do not assume content reflects current scientific knowledge, policies, or practices. 



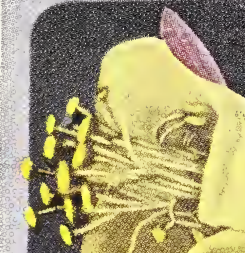
of Alosulitur.
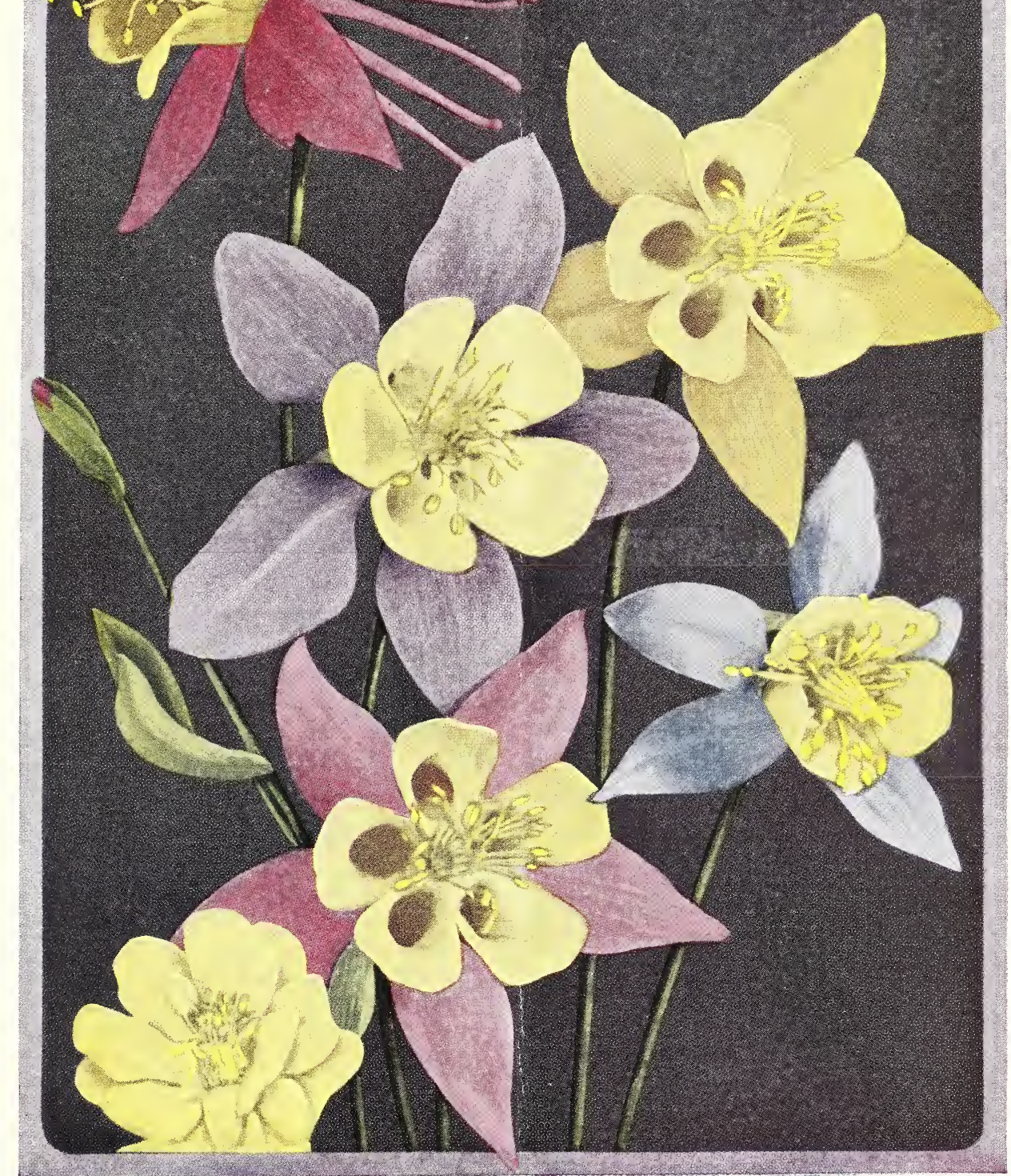

AQUILEGIA-Long Spurred Hybrids

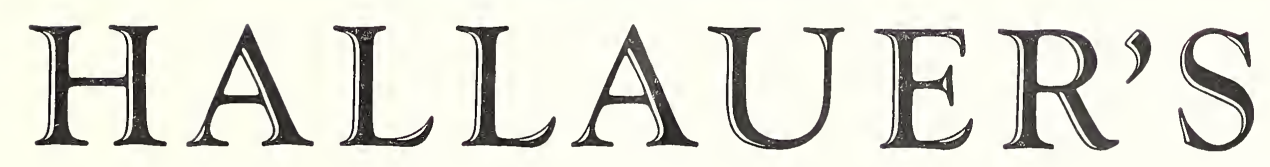

Dahlias, Gladioli, Shrubs, Roses and Old-Fashioned Hardy Perennials WEBSTER, NEW YORK 


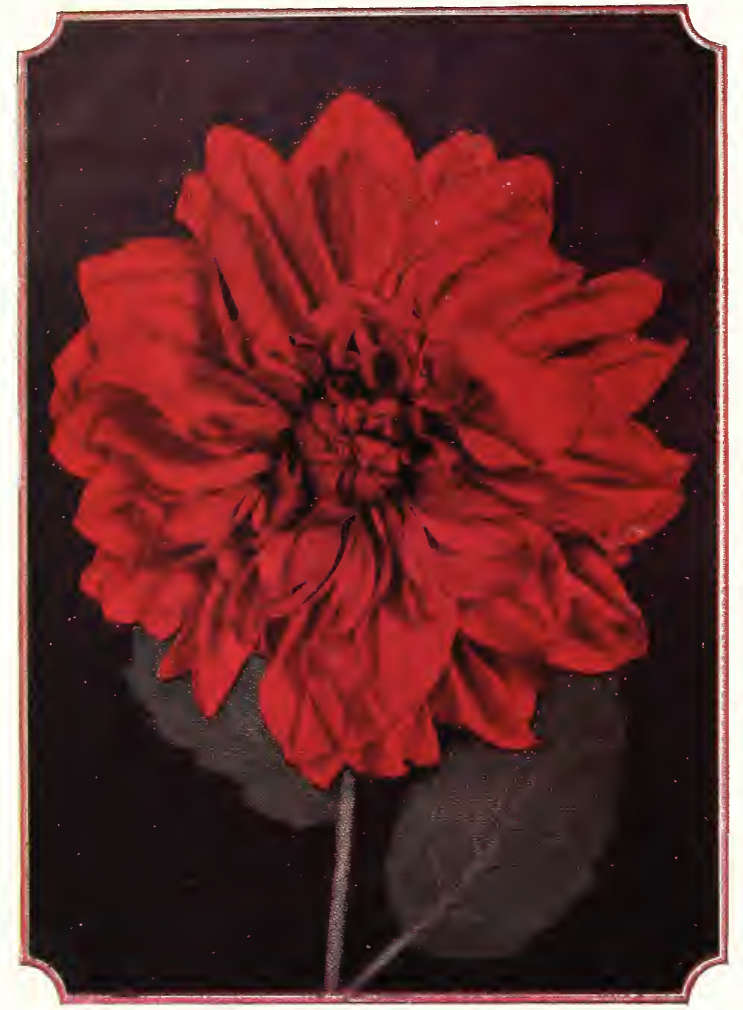

DAHLIA-The Emperor, Each, $\$ 2.00$

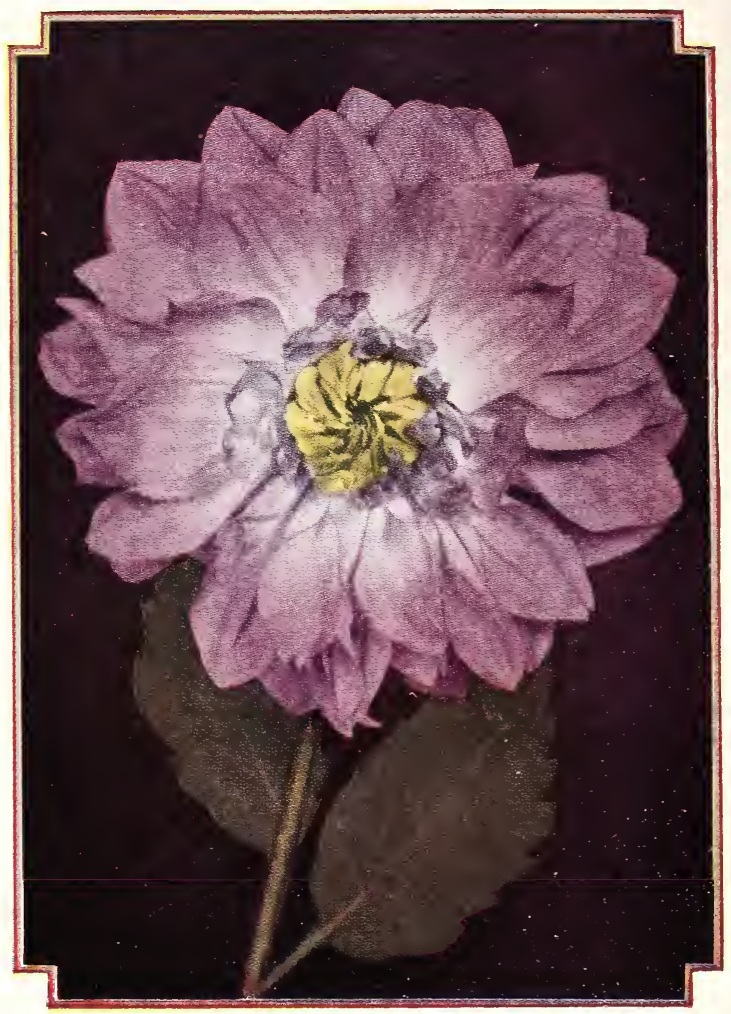

DAHLIA-Mrs. Carl Salbach, Each, 50c

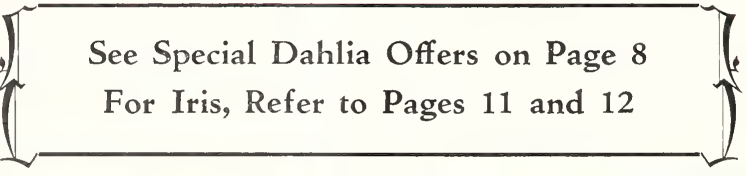

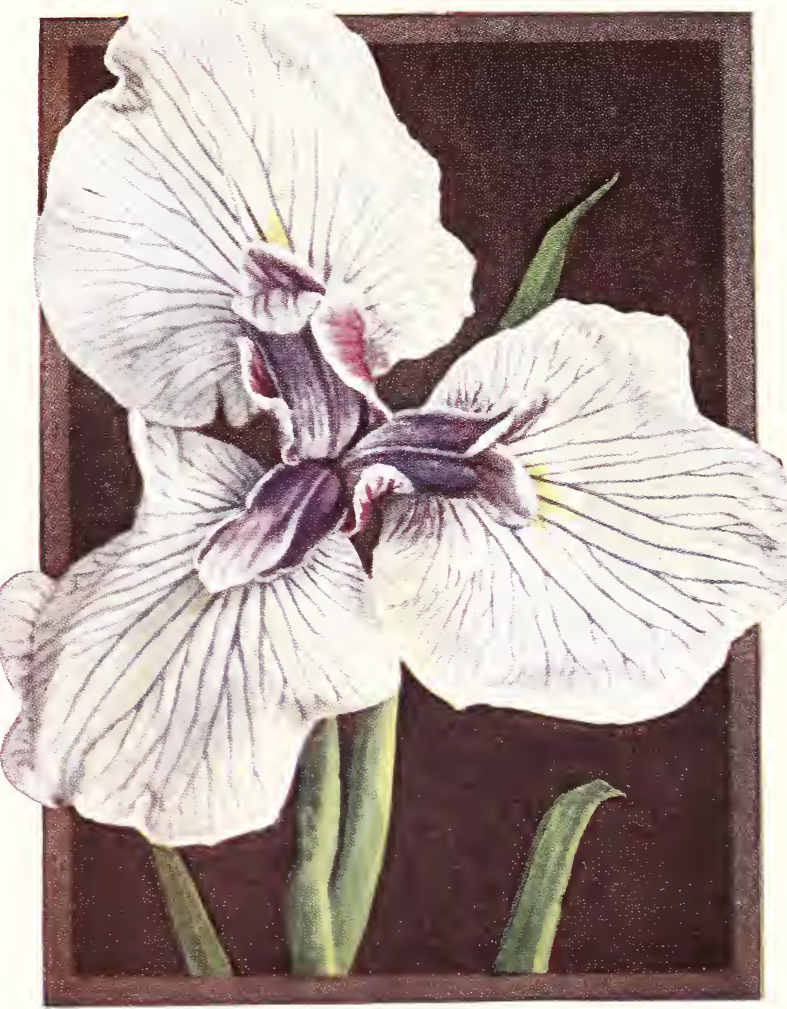

JAPANESE IRIS-(I. Japonica) No. 6, Each, 35c

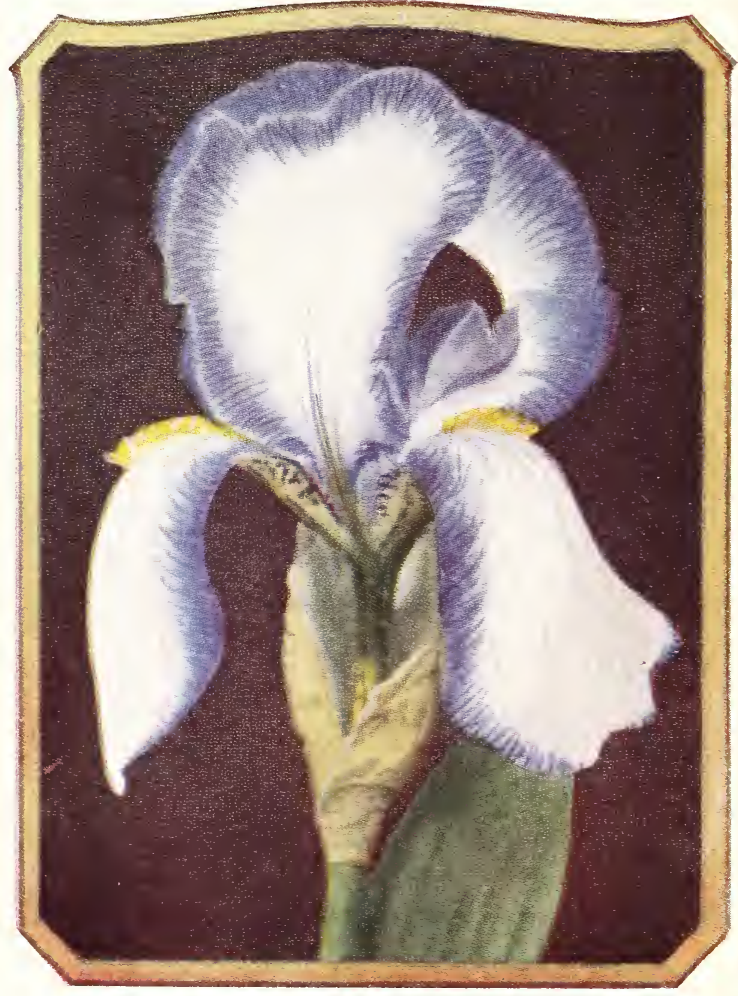

GERMAN IRIS-Madame Chereau (I. Germanica), each, 25c 


\section{Dahlias, Gladioli, Shrubs, Roses and Old-Fashioned Hardy Perennials}

In issuing this new catalog for the Spring of 1928
Ienerous patronage in the past, and I hope to
merit a continuance of their patronage

\section{GENERAL INFORMATION}

I AM always glad to welcome visitors to my gardens who are interested in hardy 1 plants and flowers. My gardens are located on the improved Ridge Road, eight miles from Rochester, one mile west of Webster Village on main highway. Rochester and Sodus Bay car stop 34 is directly in front of the place.

GUARANTEE-If I hope to retain trade, I can send only such stock as is true to name, first-class quality and in good condition when it leaves my place. Since I have no control over stock after it leaves my place, I cannot assume responsibility for failures due to improper planting or neglect after the plants have left my hands. I guarantee safe arrival of all stock sent by express. I also guarantee all stock true to name, and in a healthy growing condition when it leaves my hands. Any stock which proves otherwise will be gladly replaced or the price paid therefor refunded. I never substitute inferior varieties for those ordered, but should a variety ordered be sold out, I will fill the order with a similar or better variety, correctly labeled, unless instructions to the contrary are given in the order.

ORDER EARLY - The prices quoted in this list are as low as is consistent with the high quality of stock we send out. On account of the extreme shortage of some varieties it is very important to order early. Our stock of some of the choicest varieties is limited and it is often impossible to secure them late in the season.

IMPORTANT-When ordering, please write your name, post office, county and state plainly and give your nearest express office address, if it is different from your post office address.

CUT FLOWERS-During the blooming season we can generally supply cut flowers of Iris, Peonies, Gladioli, Dahlias and other hardy plants.

Kindly send me the names of your flower loving friends. I shall be glad to send them copies of my catalogue and will repay you by including extras with your order.

Make all remittances payable to

\section{N. A. HALlAUER, WEBSTER, N.Y.}




\section{DAHLIAS}

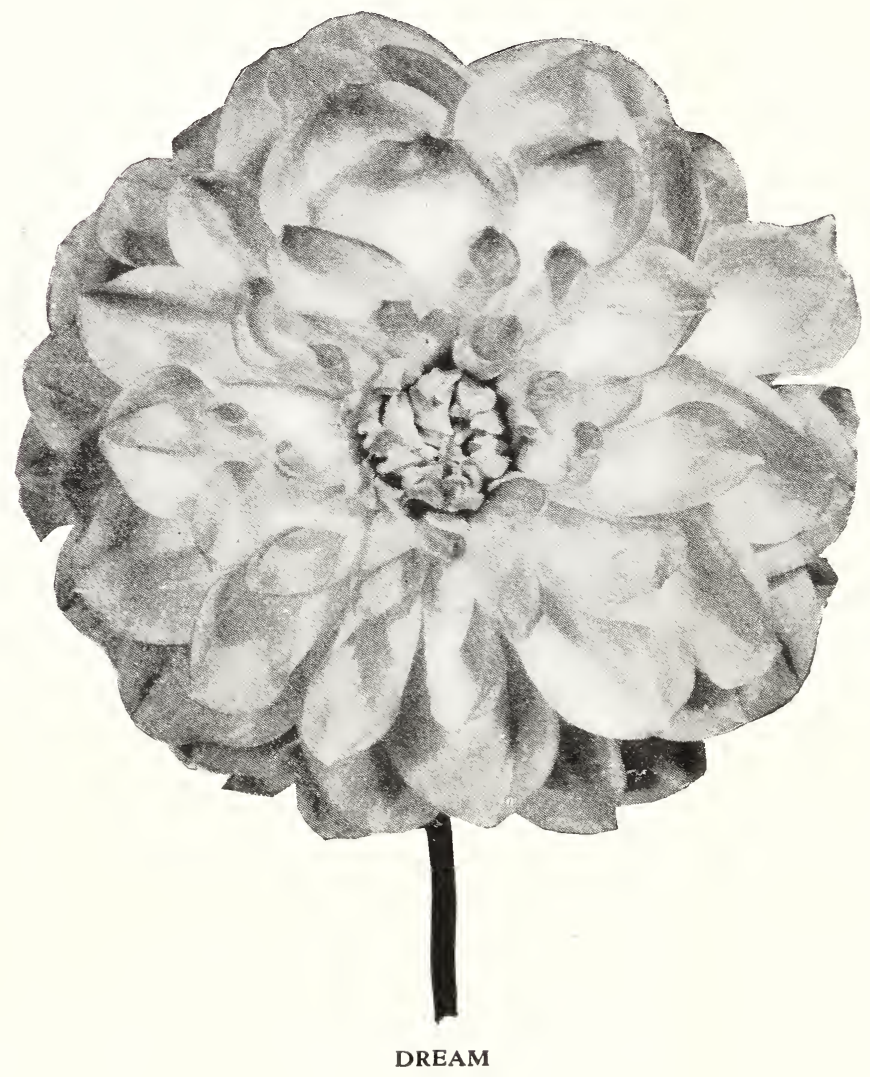

$\mathrm{C}^{4}$ ULTURE - The dahlia will grow in any good garden soil. A sandy or gravelly soil which need not be very rich suits them best. It should be worked deep and well prepared. Large quantities of manure should be avoided as it tends to produce a heavy growth of foliage at the expense of bloom. The roots should be planted $2 \frac{1}{2}$ feet apart, the tubers should be laid down flat and covered with four to six inches of soil. They may be planted as soon as frost is over, but in our climate, we have found the last half of the month of June the best time in which to plant them out. During the last of August, when the buds appear, an application of a tablespoonful of nitrate of soda spread about the base of the plant will be found beneficial in developing the blooms.

After the plants have been frozen in the Fall, dig carefully and store the roots

in a dry, cool cellar for Winter. In the Spring, the roots should be divided, preferably to one eye, before planting.

We send out divided field grown roots only. These are much more satisfactory than the weak, tender, green plants sometimes offered. If stored in a cool place, not too dry, until planted out, every one will grow. They are stored under the best possible conditions here, which preserves them in a healthy, plump condition until planting time. All stunted plants are rogued from our field to insure healthy stock.

\section{Classification of Dahlias}

CACTUS DAHLIAS-These are of recent introduction and are becoming very popular. In form they somewhat resemble the Chrysanthemum, the petals are long, narrow, incurved and sometimes twisted, giving them a very graceful appearance. (C) in the list.

DECORATIVE DAHLIAS are the largest flowering of any type. They have long, broad, flat petals. (D) in the list.

SHOW DAHLIAS are the old-fashioned large, round, compact and quilled flowered type. (S) in the list.

PEONY FLOWERED DAHLIAS are the newest type and somewhat resemble the Peony in form. The flowers are generally semi-double, exposing golden yellow disc in the center. They are very beautiful and free-flowering. (P) in the list.
POMPON DAHLAS are identical in form with show Dahlias, but are small. (Pom.)

Dahlias are sent by parcel post prepaid. Write for prices on large quantities.

ACQUISITION (S)-Beautiful deep lilac. Very large, quilled petals.

Each, 35c

A. D. LIVONI (S)-Soft pink, very free. One of the very best for cutting.

Each, 25c

ALEWINE (Pom.) - White overlaid delicate pink. A miniature W. W. Rawson.

Each, 25c

AMBASSADOR (C)-Pure white, beautiful form.

Each, 25c

AMBER QUEEN (Pom.)-Clear amber, shaded apricot.

Each, 35c 


\section{DAHLIAS - Continued}

AMUN RA-The Sun God. Brilliant copper and orange, shaded gold and deepening to reddish bronze at the center. Huge blooms on good stems.

Each, $\$ 1.00$

ANNA MAIER (D)-Bright oriental red. Excellent exhibition variety.

Each, $\$ 1.50$

ARIEL (Pom.) - Small salmon buff. Each, 35c

ATTRACTION (HC)-Very large, clear lilac rose, long stems.

Each, $75 c$

BALLET GIRL (C)-Attractive orange edged white, but varies from orange to white. Very attractive and free flowering.

Each, $\$ 1.00$

BASHFUL GIANT (D)-Apricot, shaded gold. Very large. Good exhibition variety.

Each, $\$ 1.00$

BEATRICE SLOCOMBE (D)-Ground color red, edged with gold shading to old rose pink. A very attractive variety.

Each, \$1.25

BELLE OF SPRINGFIELD (Pom.)-Brick red. Very small, good stem and very choice.

Each, 35c

BERTHA BERNSTEIN (S)-Good form, quilled petals and very free, color dark lavender.

Each, 35c

BETTY AUSTIN (H. C.) - Carmine rose shaded yellow. Medium size blossoms on good stems.

Each, 50c

BIANCA (C) - Very large, rose lilac with white shading.

Each, 75c
CARMENCITA (D)-Yellow, regularly striped red. The very large flowers are freely produced. Very popular.

Each, $\$ 1.00$

CATHERINE (Pom.)-Clear yellow, Very free. Each, 25c

CATHERINE DUER (D) - Bright crimson scarlet, free.

Each, 25c

CHATENAY (P) -Color similar to Chatenay rose; very beautiful, on long stems. Each, 35c

CIGARETTE (H. C.)-White, edged orange. Very large, on good stems and free. One of the best of the new ones.

Each, \$1.50

CLARA HARSH (Pom.)-Yellow, tipped crimson. Perfect form and very free. Each, 25c

COUNTESS OF LONSDALE (C)-Deep salmon pink. Very free. Good cutting variety.

Each, 35c

CRYSTAL (C) - Very large, long, narrow, incurved petals. Clear, soft pink. Good exhibition variety.

Each, 50c

CUBAN GIANT (S)-Dark crimson. Very large and free.

Each, 35c

DAKOTA (D)-Flame color, very brilliant. Very large on good stems. An excellent exhibition variety.

Each, $75 c$

DARKSOME (Pom.)-Very dark red or maroon. Reliable bloomer. Each, 35c

DELICE (D)-Clear pink, long stems. The best of color.

Each, 35c
BILLIE BURKE (D) - Straw, shaded buff. Produces large blooms freely. Each, 50c

BONNIE BRAE (D)-Yellow at base, shading to light pink. Very large flower on good stem. Very satisfactory.

Each, 75c

BRIDE'S BOUQUET (C) White. Free bloomer on good stems. Good cut flower.

Each, 35c

BRUNETTE (Pom.) - Deep crimson, sometimes blotched white. Each, 35c

CALEB POWERS (S) - Soft blush pink, very large and free. Each, 35c

CALIFORNIA ENCHAN. TRESS (C) - A beautiful pale pink. Large size and good substance. A choice variety. Each, \$1.00

CAMBRIA (D) -A soft rose pink shaded lighter at the center. The very large flowers are freely produced on long stems. Very fine.

Each, 75c

CANTEEN (D) - Salmon, shaded cinnamon on outer petals. An excellent cut flower variety. Each, 75c

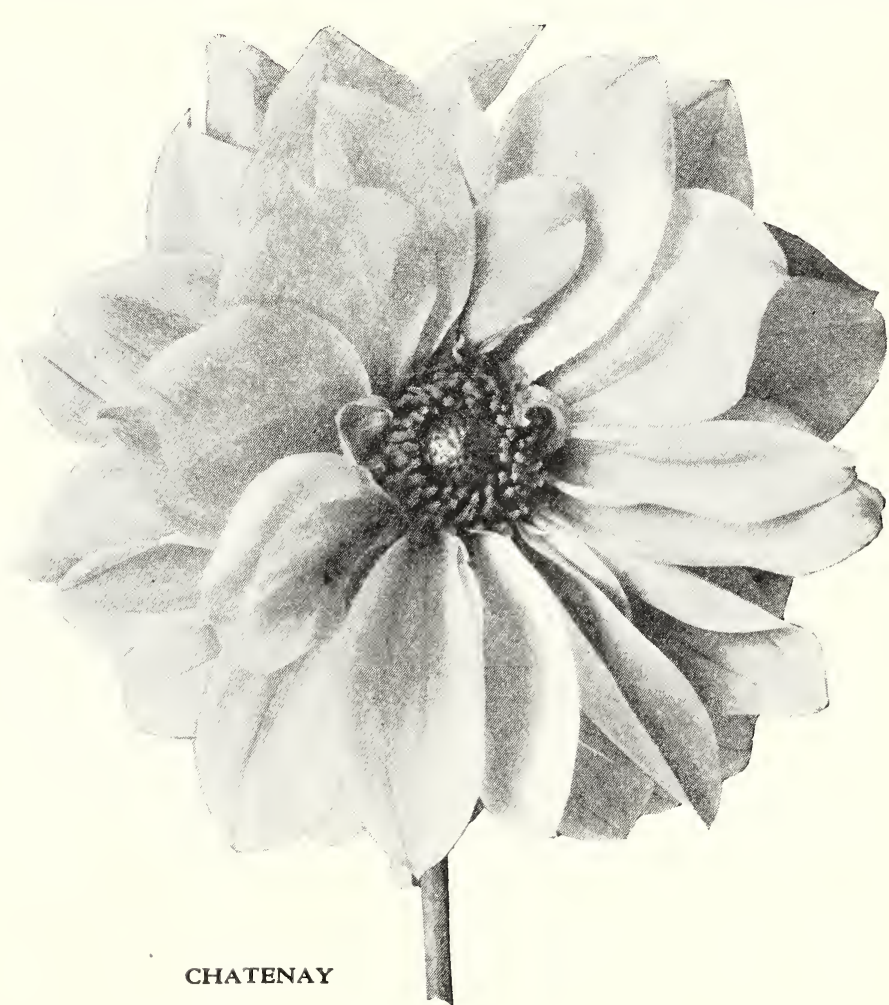




\section{DAHLIAS - Continued}

D. M. MOORE (D)-Very large, deep velvety maroon.

Each, 50c

DREAM (D) - Salmon, shaded amber. Very large. Attractive bloom on good stems. Each, 35c

DREER'S YELLOW (S)-Yellow. Quilled. An improved yellow Duke.

Each, 35c

DR. PERRY (P) - Rich, dark mahogany. Very large. One of the best.

Each, 35c

DR. TEVIS (D)-Immense, sometimes eleven inches in diameter. A beautiful salmon rose, suffused old gold and shaded golden apricot. Good exhibition or cut flower variety.

Each, 50c

DUSKY PRINCESS (D) -Very dark, nearly black, veined lighter. Free bloomer. Very distinct.

Each, \$2.00

EARL WILLIAMS (D)-Scarlet, tipped white. Striking in color, very large size and good form.

Each, $\$ 1.00$

ELSA (P)-White. Very large and free. The best white peony.

Each, 50c

ELSA BONNELL ( $\mathbf{H ~ C ) - D e e p ~ v e l v e t y ~ m a r o o n . ~}$ Very large, on long stems and very reliable.

Each, 75c

EVERETT WRIGHT (D) - Light yellow, shaded and speckled salmon. One of the most attractive variegated dahlias.

Each, \$2.00
GARIBALDI (D) - Very bright red. Large, attractive blooms are freely produced. Each, $\$ \mathbf{1 . 0 0}$

GEISHA (P) - Probably the showiest and most attractive dahlia in cultivation. The color is a brilliant scarlet and gold with a ring of clear yellow at the center.

Each, $75 \mathrm{c}$

GEORGE H. MASTICK (P)-Blackish maroon, very large, attractive flowers and extremely free bloomer.

Each, 75c

GEORGE WALTERS (HC) - Very large, hybrid cactus, salmon pink, shading to yellow at the base of the petals; one of the largest. Each, 75c

GLADYS SHERWOOD ( $\mathrm{H}$ C)-Cream white, very large and full to the center. Each, 75c

GLORY OF NEW HAVEN (D)-Clear lavender pink, distinctly veined deeper lavender. Very large and free. Useful for exhibition or cut flowers.

Each, $\$ 1.50$

GOLDEN EAGLE (C)-Faun, shaded amber. Petals long and very narrow. A very attractive variety.

Each, 35c

GOLDEN GATE (HC)-Bright, golden yellow; early and free flowering; very large, of ten measuring 9 inches.

Each, 50c

GOLD MEDAL (S)-Yellow striped red. A very large, attractive flower.

Each, 50c

GOLDEN WEST (HS)_Large, pure yellow, very free on long stems.

Each, 35c

FAITH SLOCOMBE (D) - Old gold, overlaid bronze and tinted red. Very free, on good stems.

Each, $\$ 1.00$

FANTASIQUE (P) -A semi-double flower having its petals curled and twisted in a very artistic manner. Deep wine crimson, tipped and bordered white. Novel and attractive.

Each, $\$ 1.50$

FASHION (Pom.)-Orange.

Each, 25c

FORDHOOK CERISE (P) - The name describes the color. Large and free. Each, 50c

FRANK A. WALKER (D) - A charming shade of deep lavender pink. A very free bloomer on long stems. Highly recommended.

Each, 25c

FLORADORA (C)-Dark red, fine form. Very free. One of the best.

Each, 35c

FRAU G. SCHIEFF (D) - Very large flower, golden bronze, shaded orange red. Excellent autumn shade.

Each, 75c

F. W. FELLOWS (C) - Bright orange scarlet. Long, narrow, quilled petals. Large size and free.

Each, 75c

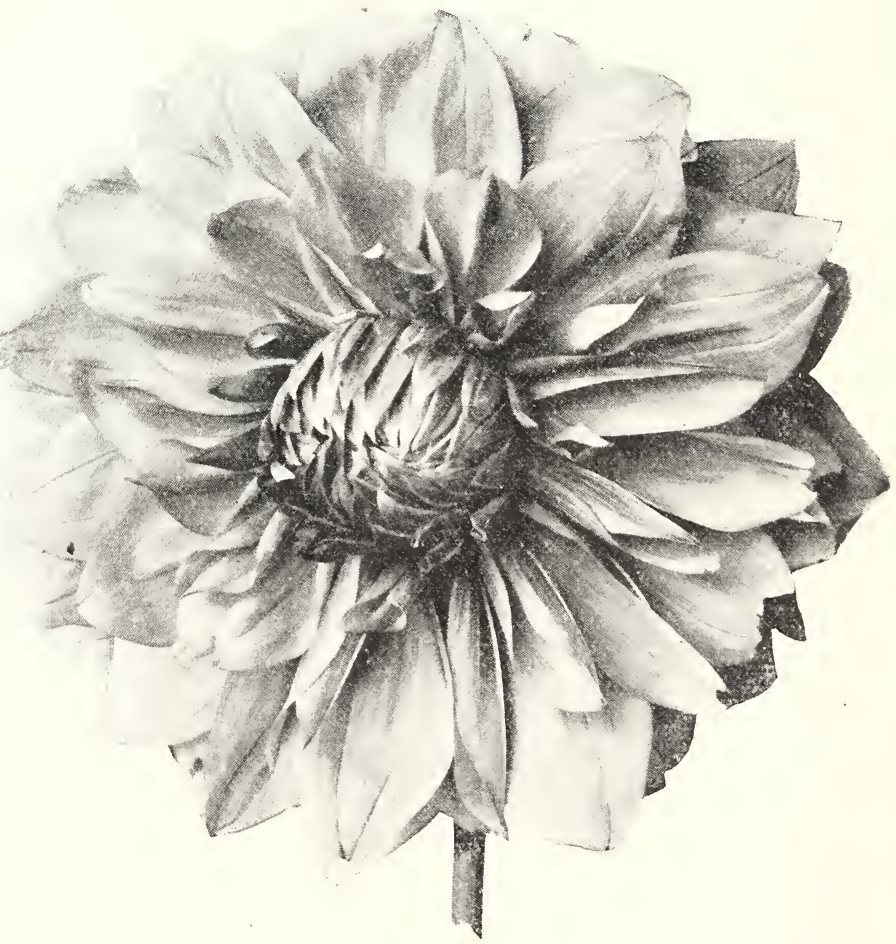

DR. TEVIS 


\section{DAHLIAS - Continued}

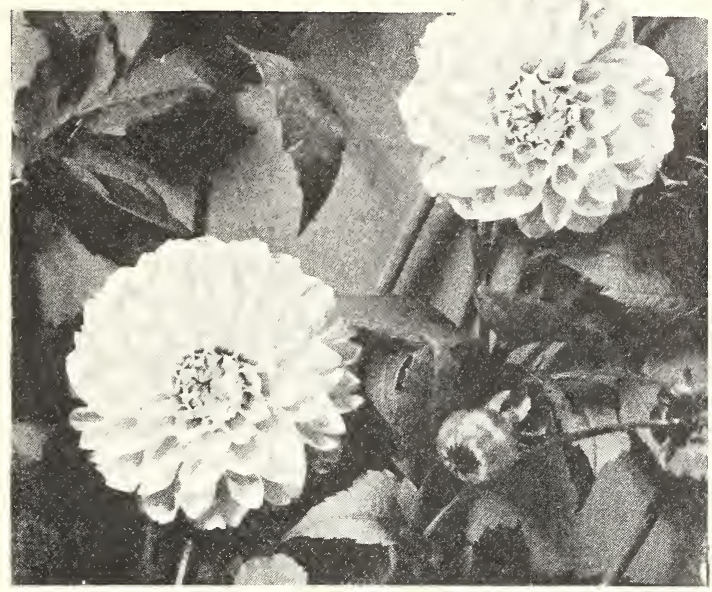

STORM KING

GRAND DUKE ALEXIS (S) - White, shaded lavender. Quilled formation. An old but popular variety.

Each, 50c

GRAPHIC (C)-Crimson, shaded maroon and tipped white. Incurved type. Good stems. Each, 25c

GRACCHUS (S) -Orange buff. Good stem and very free. One of the best show Dahlias. Each, 50c

HORTULANUS BUDDE (P)-Rich, rosy scarlet. Very large, on long stems.

Each, 35c

HORTULANUS FIET (D)-Salmon, yellow center. One of the largest. A prize winner. Each, $\$ 1.00$

INSULINDE (D)-Beautiful golden orange, very large flower on long stems.

Each, $\$ 1.00$
J. K. ALEXANDER (S)-Purple. The very best show Dahlia of this color. Each, 75c

JOE FETT (Pom.)-White. Small quilled blooms on good stems. The best white Pompom. Each, 35c

JOHNNIE (Pom.)-Deep red. Very small and free. Each, 50c

JOHN LEWIS CHILDS (D)-Yellow suffused, splashed and striped brilliant scarlet, and tipped white. Of large size and a reliable bloomer. A very attractive variety.

Each, $\$ 1.00$

JUDGE MARIAN (D) - A combination of colors, salmon, pink and red. A large, hand some flower on good stems and a profuse bloomer.

Each, $\$ 1.50$

KALIF (HC) - Rich crimson, very large, long stems; very free. One of the best

Each, $75 c$

KING ALBERT (D) -A giant in size. A bril liant violet purple. Quite distinct. Each, 75c

KITTY DUNLAP (D)-Resembles Mrs. I. de Ver Warner in color. Lilac rose. More com. pact in form. Good bloomer. Each, \$1.00

LA FAVORITA (HC) - Deep reddish salmon, good form and very attractive. Very large and free.

Each, 75c

LATONA (P) - A very attractive blending of orange, buff and yellow. Flowers nearly full, on good stems.

Each, 35c

LEADER (Pom.)-Yellow, tipped purple. A very satisfactory variety. Each, 35c
I. S. HENDRICKSON (D) - Red, intermingled with golden buff. Very attractive coloring. Of large size and a reliable bloomer.

Each, $\$ 1.50$

ISLAM PATROL (D)-Dark velvety scarlet, tipped and overlaid gold. Well formed and large size. Un usual coloring which is very attrac tive.

Each, \$2.00

JANE SELBY (D) - One of the larg est and full to the center. A beautiful mauve pink. Good for cutting or exhibition.

Each, $50 \mathrm{c}$

JEANNIE CHARMET (D) -Lavender pink. Perfect blooms on good stems. Very free bloomer. Good cut flower.

Each, 35c

JERSEY'S BEAUTY (D) - Clea pink. Perfect form and a free bloomer. Each, \$2.00

JERSEY'S GEM (D) - Lavender pink. Large, on long stems.

Each, $\$ 2.0 C$

JERSEY'S JEWEL (D) - Mallow pink. Reliable bloomer and excel. lent for exhibition. Each, \$2.50

J. H. JACKSON (C) - Rich velvety maroon. Very large. One of the best dark ones. Each, 25c

J. H. SLOCOMBE (D) - Intense deep red. Very large, on long strong stems. Each, 75c

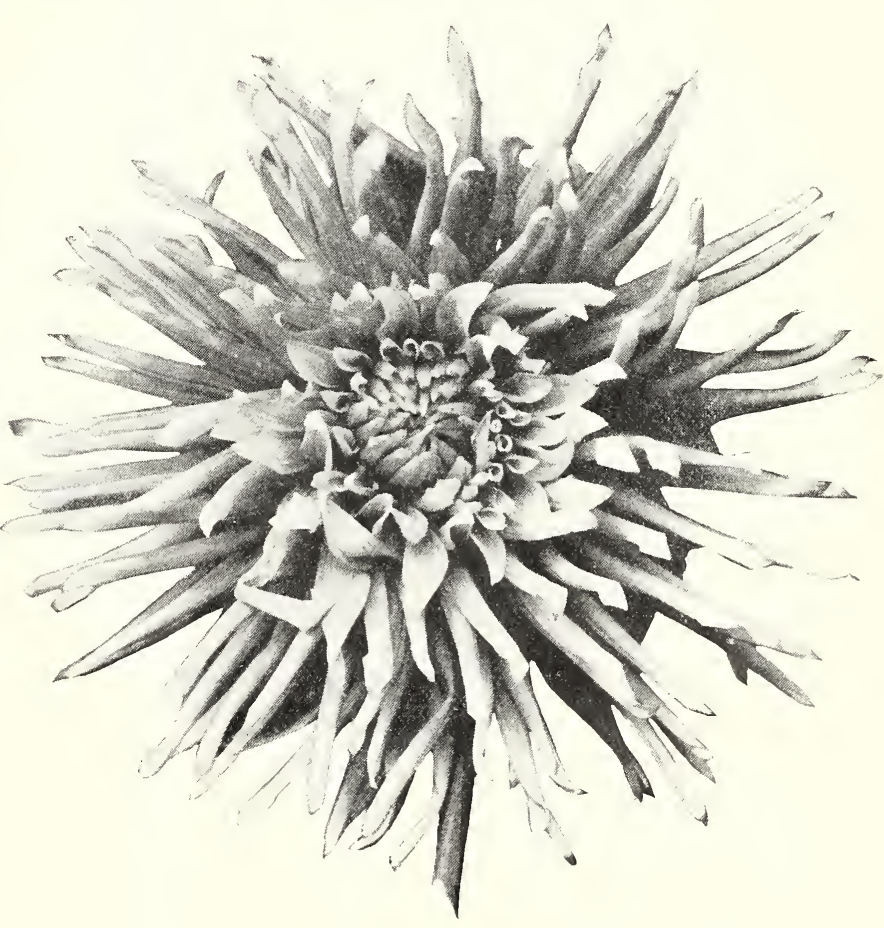

MARGUERITE BOUCHON 


\section{DAHLIAS-Continued}

LE GRAND MANITOU (D) - One of the largest and most attractive Dahlias in existence. Pure white, striped deep reddish violet. The plant occasionally bears a solid violet flower. Free bloomer.

Each, 35c

LITTLE BEAUTY (Pom.)-Soft pink. Each, 35c

MADELINE (Pom.)-Yellow edged, rose purple.

Each, 25c

MAID OF THE MIST (D) - Long pointed and twisted petals; deep cream, shading to cinnamon pink on the outer petals. Reliable bloomer. Prize winner.

Each, $\$ 1.00$

MARGUERITE BOUCHON (C) -One of the finest pink exhibition Dahlias. Brilliant rosepink with a delicate white center. Very large on long stems.

Each, $50 \mathrm{c}$

MARIPOSA (HC)-Pure pink, shaded deeper toward the center. Very attractive large flowers are produced on good stems. Each, $\$ 2.00$

MAUD ADAMS (S)-White, overlaid delicate pink. Very large, perfect form. One of the best new ones.

Each, 35c

MEPHISTOPHLES (D)-Vivid scarlet. A giant in size, held erect on good stems. Very striking and excellent for exhibition. Each, $\$ 1.00$

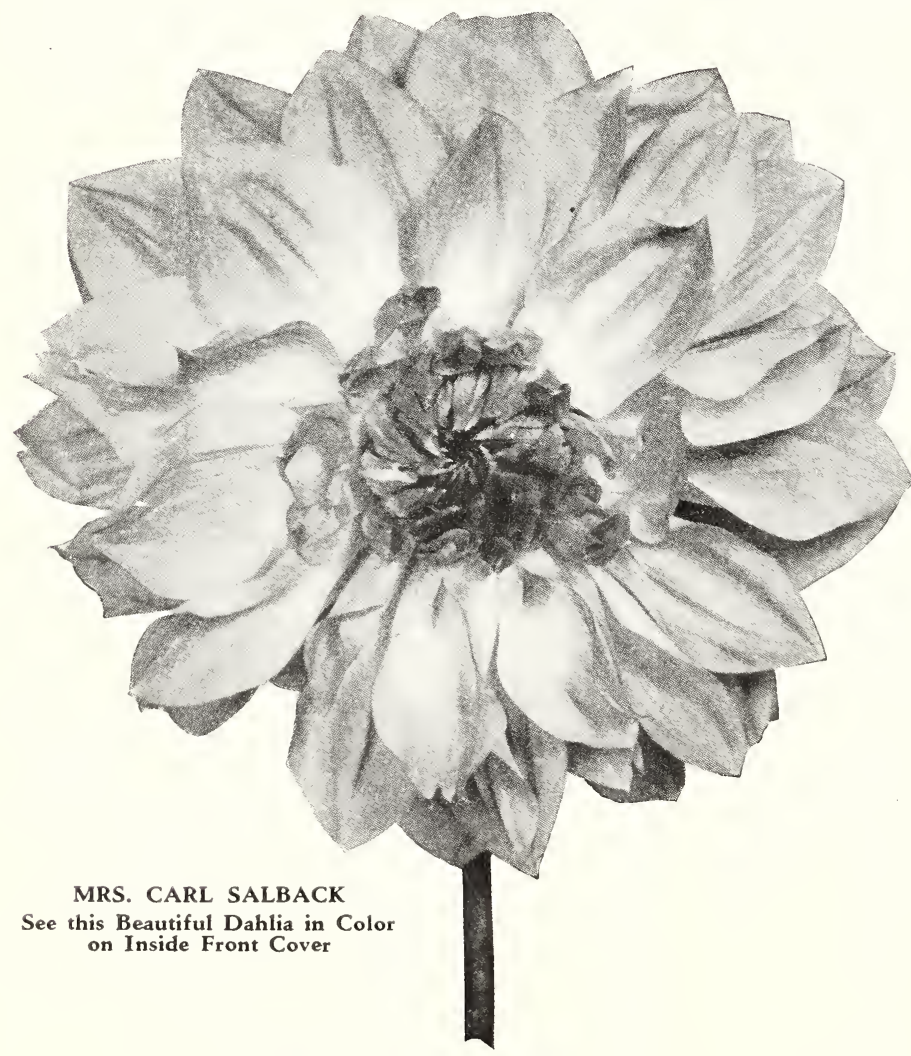

MILLIONAIRE (Stillman) (D) - Unusually large, of perfect form. Delicate lavender overcast delicate pink.

Each, 75c

MINA BURGLE (D)-Rich brilliant scarlet. Very large, on long stems. One of the best

Each, $50 c$

MONS. LENORMAND (D)-Bright yellow, striped and splashed crimson. Sometimes comes all one color. Very large striking blooms.

Each, 75c

MRS. ADDISON PRATT (D) -Buff, shaded red. Large and free.

Each, $\$ 1.50$

MRS. CHAS. TURNER (C)-Clear yellow. A very free bloomer.

Each, 35c

MRS. CARL SALBACK (D)-Mauve pink, shading to white. A monster bloom on good stems.

Each, 50c

MRS. C. G. WYATT (C)-Snow white blooms, freely produced on long stems. Incurved type. Long, narrow petals.

Each, 50c

MRS. C. H. BRECK (HC)-Soft yellow, suffused carmine, pointed petals. Each, 50c

MRS. EDNA SPENCER (C) -Lavender, very delicate, very popular. Has a good stem and blooms freely.

Each, $75 c$

MRS. E. F. T. SMITH (C) Creamy white, shaded deeper at the center. Very large, on good stems. $\quad$ Each, 75c

MRS. E. L. LINDSAY (D) Scarlet and gold. Excellent for exhibition. Each, $\$ 1.00$

MRS. JOHN L. EMERSON (D) The ground color is warm red, the petals being distinctly edged and striped with gold. Very free bloomer. One of the most attractive.

Each, $\$ 1.50$

MRS. JOHN T. SHEEPERS (D) - Canary yellow, suffused pink on the outer petals. The huge blossoms are produced with great freedom.

Each, $\$ 1.00$

MRS. NATHANIEL S L O . COMBE (D) -A deep golden yellow of good form, on long stems. Extra good. Each, 75c

MRS. I. DE VER WARNER (D)-Clear bright lilac rose. Immense flowers produced on long stems. A great favorite. Each, $\$ 1.00$

MRS. WARNAAR (HC)-Very large, creamy white, shaded pink. A new variety of great merit. Each, 75c

MR. ALEXANDER WALDIE (D) - Cream, overlaid salmon pink. Resembles Bonnie Brae. Fine for exhibition. Each $\$ \mathbf{1 . 0 0}$ 


\section{DAHLIAS-Continued}

NIEBELUNGINHORT (C)-Violet rose, suffused apricot. Very large and free.

Each, $50 c$

PATRICK O'MARA (D)-Orange buff. Very large blooms on good stems. Strong grower and free bloomer.

Each, 50c

PAUL MICHAEL (D)-Sometimes called California Gold; deep buttercup yellow, shaded old rose. One of the largest. Very free bloomer.

Each, $\$ 1.00$

PEE WEE (Pom.)-Yellow, tipped bronze; very small.

Each, 50c

PERLE DE LYON (C)-Pure white. The petals are cleft, giving the flowers an attractive appearance. Excellent for cutting.

Each, 35c

PIERROT (C) - Very large narrow petals, deep amber, boldly tipped white. Very striking.

Each, 50c

PORTHOS (D)-Dark red. A very unusual type. Very free.

Each, $50 c$

PRINCESS JULIANA (D)-Dure white. Very long stems, medium size. Very free. The best white for cutting.

Each, 35c

PRINCESS VICTORIA (S)-Pure canary yellow, perfect form, long stems, very free. Each, 25c

PURE LOVE (Pom.)-Lavender blue, perfect form. Each, 35c

QUEEN EMMA (P)—Rose pink, suffused yellow. Each, 25c

QUEEN WILHELMINA (P)-Pure white; very large. The best white.

Each, 25c

RED CROSS (HC)-Very large, on good stems. The color is a very attractive combination of scarlet and gold.

REINE CAYEUX (C) - Medium sized flowers, rich geranium red. Always good. Each, 35c

REINISHER FROHSINN (C) White at the base of petals, quickly changing to crimson. Excellent for cutting. Each, 75c

ROSA BONHEUR (HC) Beautiful shell pink, shading to a cream white center. Very large, on good stem; excellent exhibition variety.

Each, $\$ 2.00$

ROSA NELL (D) - Bright rose. Extremely large blooms on good stems.

Each, 75c

RUBE GIRL (C) - Soft yellow suffused and tipped coral red. Very profuse bloomer on good stems.

Each, 35c

RODMAN WANAMAKER (D) -Pale lemon yellow, changing to salmon pink. Can be grown to huge proportions by disbud. ding.

Each, $\$ 4.00$

SAMSON (D)-Gold and scarlet, blended with shades of orange. Very attractive coloring. Flow ers of large size, good form and freely produced. One of the very best.

Each, \$2.00

SAN MATEO (D)-Deep yellow, heavily striped and splashed scarlet. A very large and attractive flower, good for any purpose. Each, $\$ 1.50$
SILVER HILL PARK (C)-White, shaded cream. Narrow incurved petals.

Each, $75 \mathrm{c}$

SNOWCLAD (Pom.)-Pure white. Each, 25c SOUVENIR DE GUSTAVE DOUZON (D)A pleasing shade of orange scarlet. Each, 35c

STANDARD BEARER (C)-Bright scarlet. One of the best.

Each, 35c

STORM KING (S)-Pure white. Exceedingly free and very popular. Good cut flower.

Each, 25c

SUNBEAM (Pom.)-Bright scarlet. Very fine. Each, 25c

THE BILLIONAIRE (P) - Attractive golden orange. One of the largest in cultivation.

Each, $\$ 1.00$

THE EMPEROR (D)-Maroon. Its large size, deep color and excellent form combine to make this one of the best exhibition Dahlias.

Each, $\$ 2.00$

THE GRIZZLY (D)-Deep maroon. A very large flower on long stems. A free bloomer.

Each, $\$ 1.00$

THE U. S. A. (H. C.)-Deep orange. Very large flowers, long, incurved petals. Long stems. Very distinct variety.

Each, $\$ 1.50$

THE MERMAID (D)-Soft yellow with outer petals of cinnamon pink. Good form and long stem.

Each, $\$ 1.50$

VENUS (D)-Creamy white, suffused lavender. Large flowers are very freely produced on long stems.

Each, $\$ 1.00$

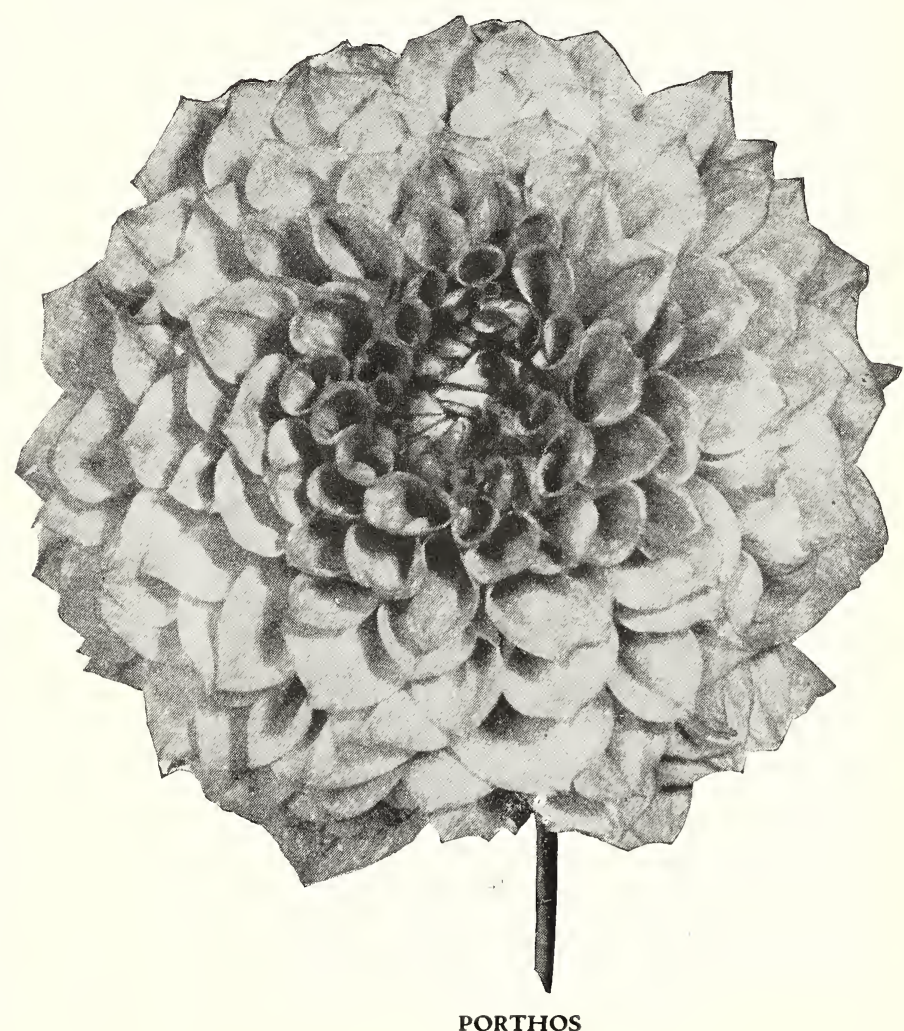




\section{DAHLIAS - Continued}

VIVIAN (S) - White, edged rose violet, new and very choice.

Each, 25c

WINFIELD SLOCOMBE (D)-Gold, shading to burnt orange. The very large blooms are very freely produced on long stems. The Slocombe gardens usually send out good dahlias. This is probably their best.

Each, \$2.50
WODAN (HC) - Beautiful salmon rose, shading to old gold at the center. Very large, semi-in. curved form.

Each, 50c

YELLOW KING (HC)-Clear light yellow. Large blooms on long stems. Resembles Attrac. tion in form and size.

Each, 35c

\section{DAHLIA SPECIALS}

$\begin{array}{clcc}\text { Blue Ribbon Collection } & \$ 12.95 \text { Prepaid } & \text { Ten Choice Varieties } & \text { for } \$ 4.95 \text { Prepaid } \\ \text { Cigarette } & \text { Judge Marian } & \text { Attraction } & \text { La Favorita } \\ \text { Earl Williams } & \text { Mariposa } & \text { Dakota } & \text { Mrs. Carl Salback } \\ \text { Faith Slocombe } & \text { Mrs. J. T. Sheepers } & \text { Dr. Tevis } & \text { Mrs. Edna Spencer } \\ \text { Jersey Beauty } & \text { Samson } & \text { Geo. H. Mastick } & \text { Patrick O'Mara } \\ \text { Jerseys Jewel } & \text { The Emperor } & \text { Gold Medal } & \text { Porthos }\end{array}$

Seven Selected Pompoms for $\$ 2.35$ Prepaid

$\begin{array}{ll}\text { Ariel } & \text { Joe Fett } \\ \text { Belle of Springfield } & \text { Johnnie } \\ \text { Catherine } & \text { Little Beauty } \\ \text { Fashion } & \end{array}$

\section{GLADIOLI}

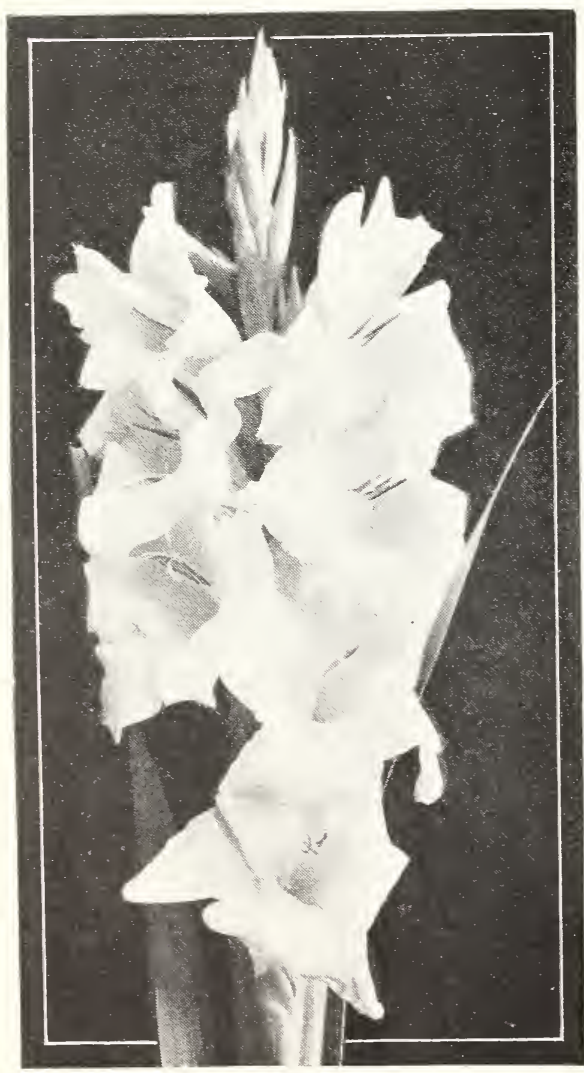

FLORA
GLADIOLI are of very easy culture. The bulbs may be planted as early as the ground can be worked and for a succession of bloom every two weeks up to July. The ground should be dug deeply and the bulbs planted 4 to 6 inches apart in the rows and 5 or 6 inches deep. A rich sandy loam soil in full sun suits them best, although they will thrive in any good garden soil.

One bulb of a variety at 1-10th the list price per dozen, prepaid. Write for prices on larger quantity.

ALICE TIPLADY (K)-A grand, large Primulinus of beautiful orange saffron color. Doz., $\$ 1$.00 AMERICA-Large, clear lavender pink. The best pink. Doz., $50 c$

ARGO (K) - The Primulinus Myrtle. Large. Doz., \$1.00 ATTRACTION-Large, rich, dark crimson; clear white throat.

Doz., $\$ 1.00$

AUGUSTA-Pure white, blue anthers. Doz., 50c

BARON HULOT-Rich, deep indigo blue. The best blue.

Doz., $\$ 2.00$

BYRON L. SMITH (K)-Beautiful lavender pink on white ground. Very choice. Doz., \$2.00

CHICAGO WHITE-White, faint throat markings; early.

Doz., $50 c$

CINNAMON BEAR (K)-Rich, deep violet red. Large and fine. Ruffled.

Doz., $\$ 2.00$

CONSPICUOUS -Light blue, dark blue blotch and yellow center.

Doz., $\$ 1.50$

CRIMSON GLOW-Tall, straight spike of a bright red color.

Doz., $\$ 1.50$ 


\section{GLADIOLI-Continued}

E. J. SHALER (K)-Pure deep rose pink. Very large and choice. Ruffled.

Doz., $\$ 2.00$

EMPRESS OF INDIA-Rich, deep purplish crimson. Very attractive.

Doz., $\$ 1.00$

EVELYN KIRTLAND-New. The flowers of strong substance, are a beautiful shade of rosy pink, darker at the edges, fading to shell pink at the center, with brilliant scarlet blotches on lower petals. Wide, open flowers, slightly fluted and many open at a time. Very tall, straight spikes. One of the best.

Doz., $\$ 1.00$

FLORA-Golden yellow. First-class in every respect. Doz., \$1.50

GLORY OF KENNEMERLAND-Rose pink, yellow throat markings. Individual flowers very large.

Doz., $\$ 1.00$

GOLDEN MEASURE-Pure yellow self. Tall spike. Many open at once.

Doz., $\$ 2.00$

GOLDEN WEST-Bright orange red, shaded yellow and striped darker. Very attractive color.

Doz., $\$ 1.00$

GRETCHEN ZANG-New. The blossoms are large and sparkling, and the most beautiful soft melting shade of pink, blending into scarlet on the lower petals. The color everyone wants. Spike tall and graceful.

HALLEY - Delicate salmon pink, creamy blotch on lower petals with red stripe.

Doz., $50 \mathrm{c}$

HERADA-New. Another good one. Blooms of immense size on tall, straight spikes. Massive in every way. The large blooms are pure mauve, glistening and clear, with deeper markings in the throat. A very striking and attractive color

Doz., $\$ 1.50$

LILY WHITE-Pure white, without markings. Type of Chicago White. Early bloomer.

Doz., $\$ 1.00$

MARY FENNELL (K) — Light lavender, lower petals penciled yellow.

Doz., $\$ 1.50$

MARY PICKFORD (K) - Delicate creamy white. Stem and calyx also white.

Doz., $\$ 1.50$

MRS. DR. NORTON (K)-White edged, soft pink, yellowish blotch. Doz., $\$ 1.50$

MRS. FRANCES KING-Flame pink, a very tall spike, flowers very large. Doz., 50c

MRS. FRANK PENDLETON, JR. (Kundred) - Very large, wide open flowers, bright salmon pink with blood red blotch on lower petals. Very attractive. Doz., \$1.00

MRS. WATT-American beauty, self color. Strong, healthy grower. Doz., $\$ 1.50$

MURIEL-Orchid blue with purple marks. One of the best blues. Doz., \$2.50

MYRA (K) - A giant flowered Primulinus variety. Tall, deep salmon on white ground.

Doz., $\$ 1.50$

NORA-Lavender blue, dark blotch. A very good variety.

Doz., $\$ 1.50$

ORANGE GLORY (K) - Clear orange, shaded lighter in the throat. A very beautiful ruffled variety.

Doz., $\$ 2.00$

PANAMA-Another seedling of America, but is larger, taller and of a deeper color. A prize winner.

Doz., $\$ 1.00$

PEACE-Very large white with faint markings on lower petals.

Doz., $\$ 1.00$

PINK PERFECTION-La France pink. Large, open flowers. One of the best. Doz., $\$ 1.50$

Doz., $\$ 1.00$

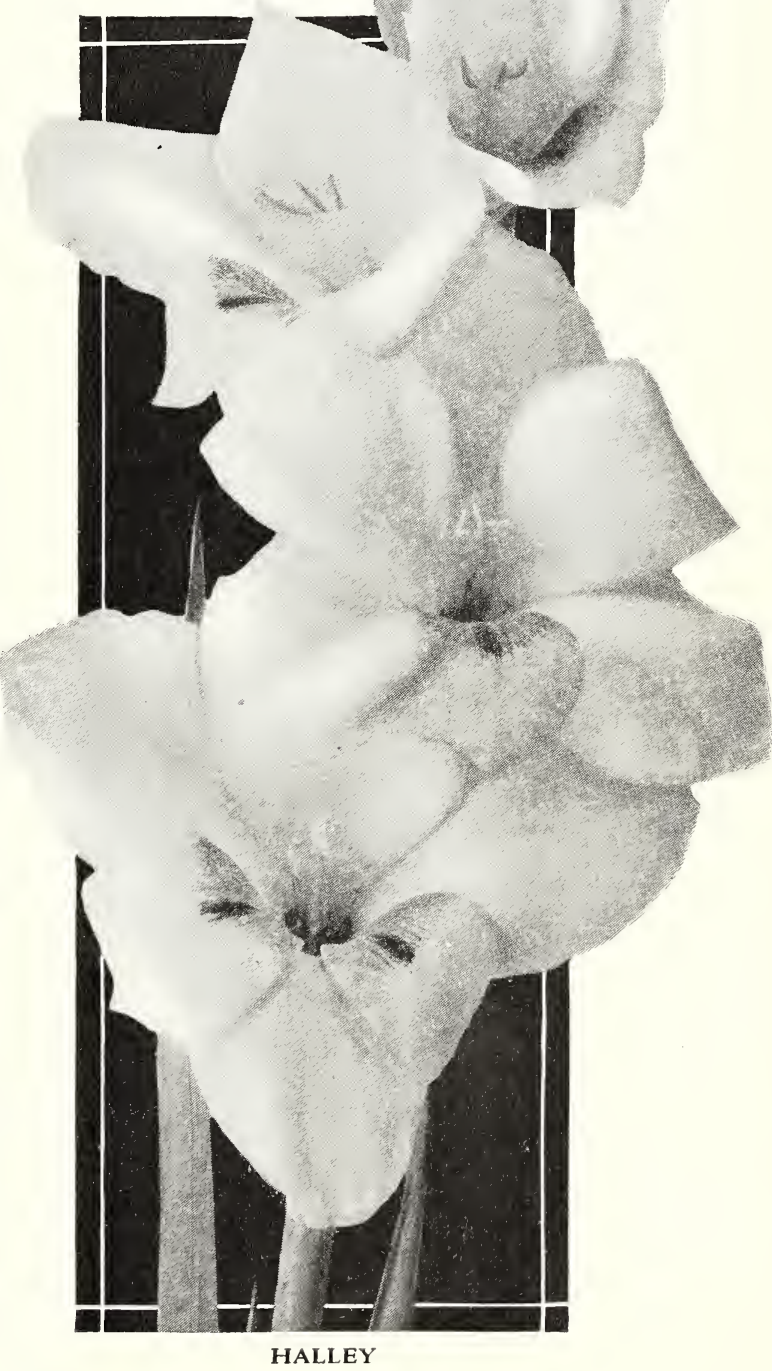




\section{GLADIOLI-Continued}

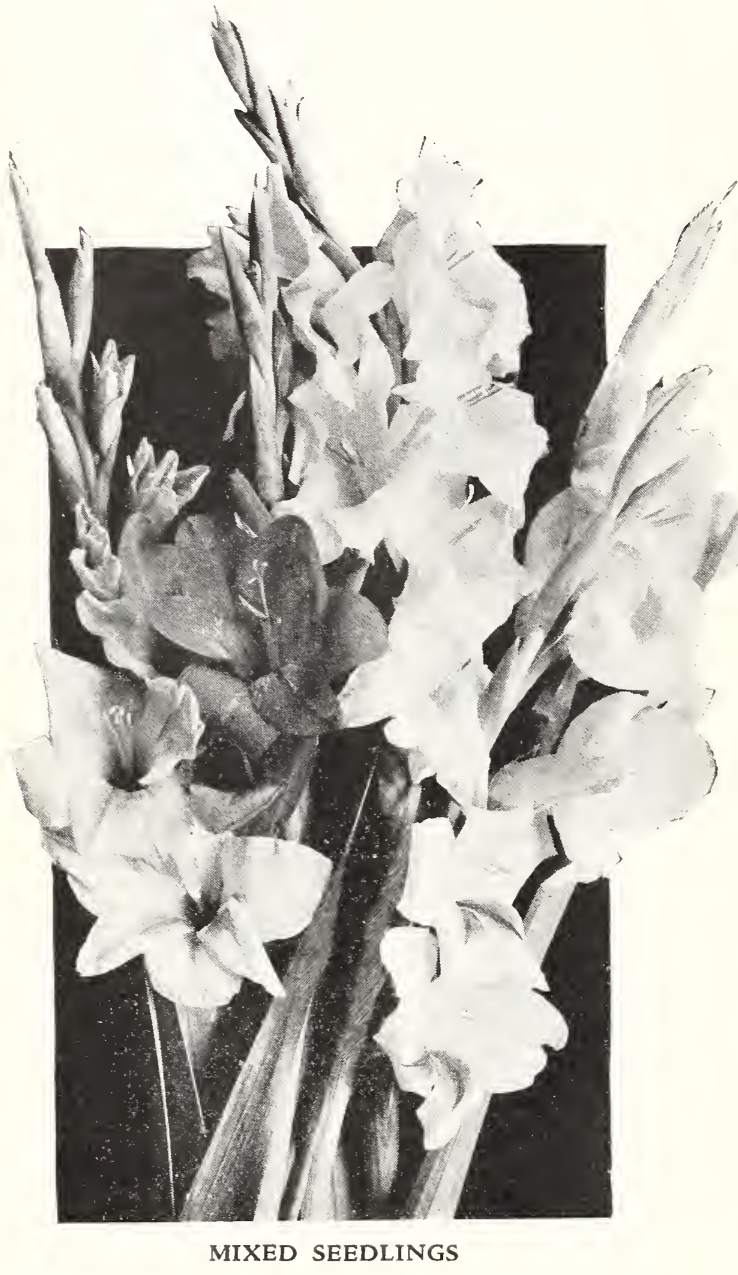

PRIMULINUS HYBRIDS-Beautiful shades of yellow and orange. Very graceful.

Doz., 50c

PRINCE OF WALES-Pale salmon; self color; large and early.

Doz., $\$ 1.50$

PURPLE GLORY (K)-A veritable giant, deep, velvety maroon, with almost black blotches. Beautifully ruffled. Doz., \$2.50

ROANOKE (K) - Large, rich yellow Primu. linus. One of the best of its class.

Doz., $\$ 2.00$

SALMON BEAUTY (K)-Deep salmon, salmon yellow throat. Very large Primulinus. Doz., $\$ 1.00$

SCARLANO $(K)$ - Light orange red. A very attractive ruffled variety. Doz., $\$ 2.00$

SCARLET PRINCEPS (K)-Clear scarlet. Massive bloom and spike. Doz., \$2.50

SCHWABEN - Delicate pale yellow, dark blotch. Very large flower and spike.

Doz., $\$ 1.00$

SOUVENIR-Primulinus. Pure golden yellow. The best yellow Primulinus. Doz., $\$ 2.50$

VIOLET GLORY (K) -Ruffled. Deep violet maroon. Rich coloring. Doz., \$2.50

WAR-Deep blood red, shaded darker. Tall spike. Very attractive. Doz., $\$ 1.50$

YELLOW HAMMER-Primrose yellow. Small, inconspicuous blotch. Excellent substance.

Doz., $\$ 1.00$

ALL COLORS MIXED-A choice mixture of Silver Trophy, to which have been added some choice named varieties. All good.

Doz., $40 c$

MIXED SEEDLINGS-Selected seedlings of my own raising. Not a poor variety among them. Impossible to obtain a better collection of choice varieties for the money.

Doz., $\$ 1.00$

\section{GLADIOLUS SPECIALS}

Giant Collection-1 dozen prepaid for $\$ 2.00$

1 bulb each of the following varieties:

Byron L. Smith

E. J. Shaler

Evelyn Kirtland

Golden Measure

Mary Pickford

Mrs. F. Pendleton
Mrs. Watt
Muriel

Mrs. Watt
Pink Perfection

Purple Glory

Scarlet Princeps

\section{SPECIAL FOR CUT FLOWERS}

$\begin{array}{llll}\text { America } & \text { Lily White } & \text { Mrs. Frank Pendleton } & \text { Salmon Beauty } \\ \text { Halley } & \text { Mrs. F. King } & \text { Peace } & \text { Schwaben }\end{array}$

Six large bulbs of each of the above, 4 dozen in all, for $\$ 2.25$

Twenty-five large bulbs of each of the above, 200 in all, for $\$ 7.50$ 


\section{R IS}

\section{German Iris}

$\mathrm{T}$ HESE are among the most delicately beautiful of the hardy perennials. They thrive in almost any soil or situation except that they cannot endure standing water. They may be planted in early Spring, but best results are obtained by planting in August and September.

In the following descriptions, $S$ is for standards, or upper petals, and $F$ for falls, or lower petals.

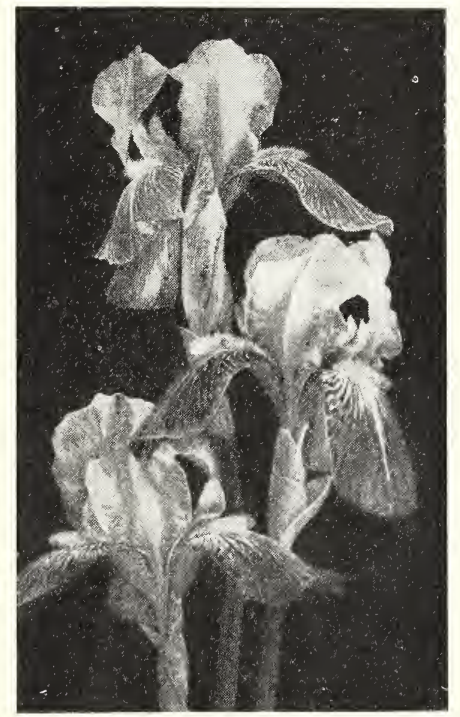

AGNES - S. White, frilled and shaded lilac; F White, traced lilac.

$2 \mathrm{ft}$., Each, 25c

ALCAZAR - S. Light bluish violet; F. Deep purple, veined bronze at the throat. A very handsome variety

Each, 50c

AUREA-Clear lemon yellow, self. Each, 25c

CAPRICE-S. Rosy red; F. Rosy red with yellow beard. Very beautiful. $2 \mathrm{ft}$., Each, 35c

FLAVESCENS - S. and F. Delicate soft yellow. Large, sweet scented. Early. 30 in., Each, 25c

FLORENTINA ALBA-Creamy white, fragrant. Early.

2 ft., Each, 25c

GERTRUDE-S. and F. Beautiful blue. Early. Each, 25c

HER MAJESTY - S. Lovely rose pink; F. Bright crimson, shaded darker. Very handsome.

Each, 35c

HONORABILIS (Syn. Sans Souci)-S. Golden yellow; F. Rich mahogany. 18 in., Each, 25c

INNOCENZA-Ivory white. 18 in., Each, 25c

IRIS KING-S. Clear lemon yellow; F. Rich maroon, bordered yellow. Maori King X Pallida. Large and beautiful.

Each, 35c

ISOLENE-S. Silvery lilac; F. Mauve with orange beard. Large and beautiful form. Each, 50c

KHEDIVE-Soft lavender. $\quad 33$ in., Each, 25c KOCHII-Rich claret purple, self. Very hand. some.

Each, 25c
LOHENGRIN-Uniform soft shade of Cattleya rose. Very large. Each, 35c

LORELEY - S. Light yellow; F. Ultramarine blue, bordered cream.

Each, 25c

MAD. CHEREAU-White, elegantly frilled, clear blue. Very handsome. 32 in., Each, 25c

MAD. PAQUETTE-Bright rosy claret. The best "red." 42 in., Each, 35c

MARY GARDEN-S. Pale yellow, flushed pale lavender; F. Creamy white, dotted and veined maroon. $2 \mathrm{ft}$., Each, 35c

MONSEIGNOR - S. Rich satiny violet; F. Purple-crimson, margined lighter. Very large.

Each, 35c

MRS. H. DARWIN-Pure white, falls slightly reticulated violet at base. One of the best whites.

2 ft., Each, 25c

NEIBELUNGEN-S. Fawn yellow; F. Violet purple suffused creamy white. New. Each, 35c

PALLIDA DALMATICA - S. Lavender; F, deep lavender. A superb variety. 40 in., Each, $25 \mathrm{c}$

PFAUENAGE-S. Olive gold; F. Plum color with gold border. Very beautiful. New.

15 in., Each, 35c

PLUMERI-S. Coppery rose; F. Velvety claret.

Each, 25c

PROSPER LAUGIER-S. Light bronze red; F. Velvety ruby-purple. Each, 50c QUAKER LADY - S. Smoky lavender, shaded yel low; F. Aegeratum blue and gold, yellow beard. 38 in., Each, 50c

QUEEN OF MAY-Soft rose lilac, almost pink. 32 in., Each, 25 c

RHEIN NIXE-S. Pure white; F. Deep violet blue, edged white. Very attractive. New. Each, 35c

ROSE UNIQUE-Bright violet rose. Said to be the nearest approach to a pink Iris. Each, 35c SEMINOLE-S. Violet; F, Crimson. Large and attractive. 2 ft., Each, $\$ 1.00$

SHERWIN WRIGHT-Golden yellow, self. Very free flowering. Each, 35c STENOPHYLA-S. Pale lilac; F. Violet. Each, 25c

VIOLACEA GRANDIFLORA-S. Rich blue; F Violet blue. Large and handsome. Each, 25c

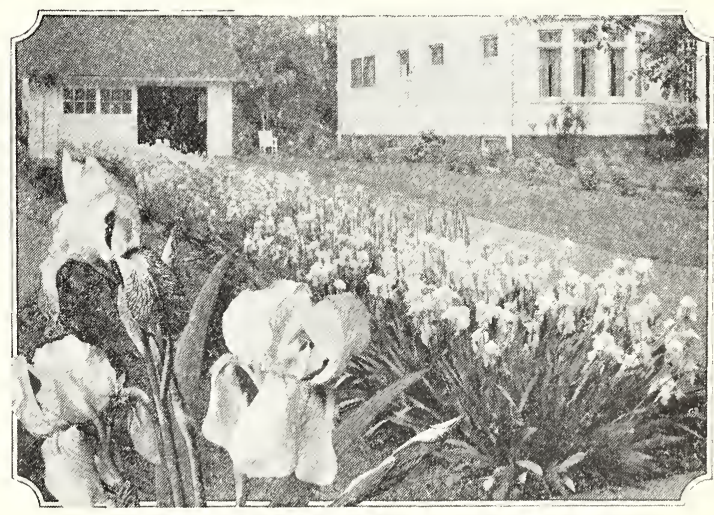

A PLEASING BORDER OF GERMAN IRIS 


\section{Intermediate Iris}

Handsome new hybrids blooming between the dwarf Pumilla and later blooming German Iris. They are all large flowering. HALFDAN-Creamy white.

Each, 25c

HELGE--Lemon yellow, shaded pearl. Each, 25c IVORINE-Large creamy white. Each, 25c

\section{Iris Special}

One each of the following ten choice varieties for $\$ 3.00$ prepaid, two each, twenty in all, for $\$ 5.50$

$\begin{array}{ll}\text { Alcazar } & \text { Mad. Chereau } \\ \text { Flavescens } & \text { Quaker Lady } \\ \text { Her Majesty } & \text { Rhein Nixe } \\ \text { Isoline } & \text { Sherwin Wright } \\ \text { Kochi } & \text { Violacea Grandiflora }\end{array}$

\section{Iris Siberica}

These have long, narrow foliage with tall stems of medium-sized flowers. They bloom very freely and are excellent for cut flowers. ORIENTALIS BLUE KING-Large, handsome clear blue. ORIENTALIS SNOW QUEEN-Large, ivory white flowers. Each, 25c *IRIS CRISTATA-A native creeping species. Rich amethyst blue. Fine for the rockery.

Each, 35c

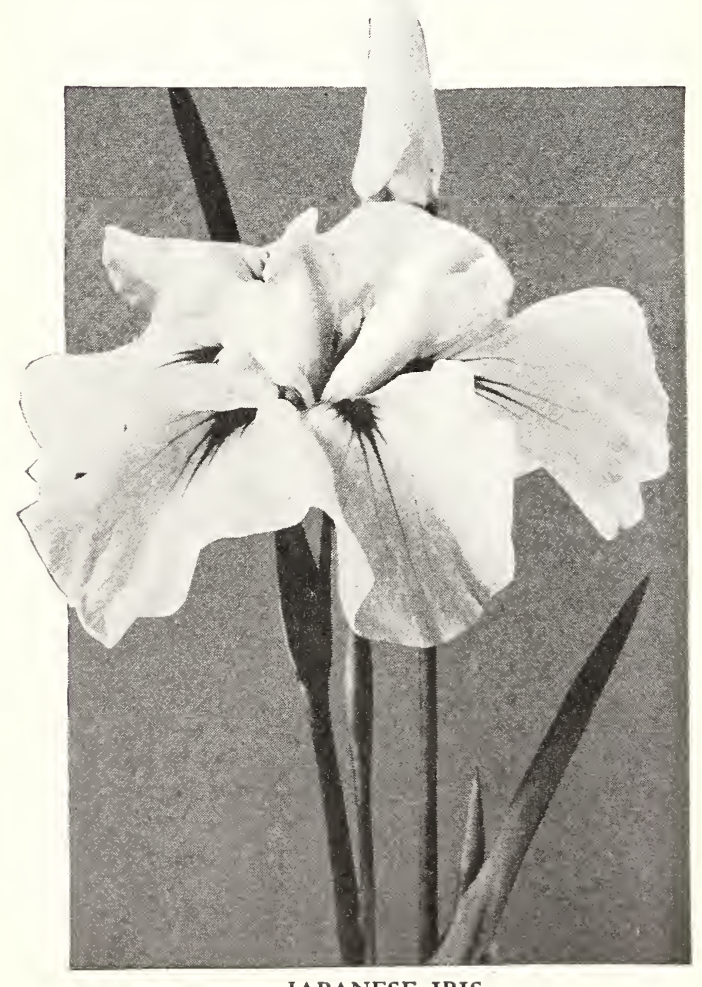

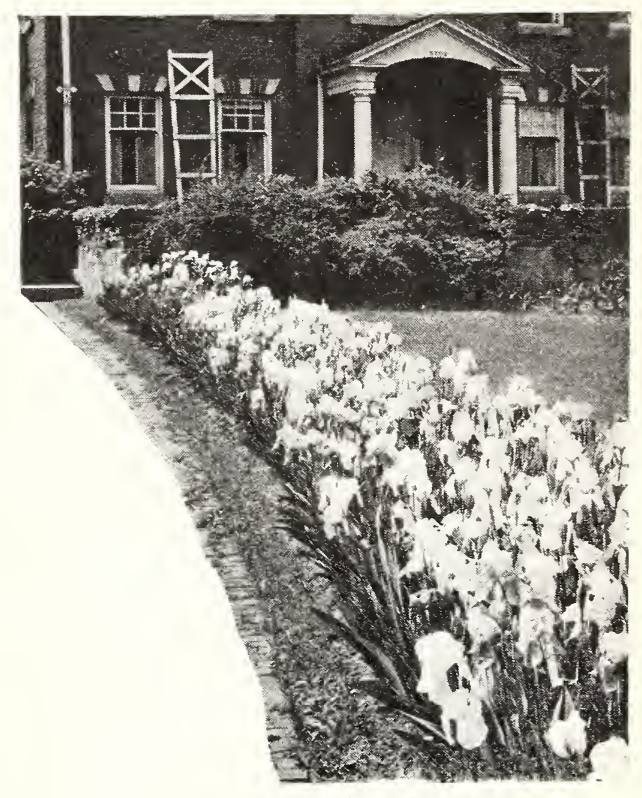

GERMAN IRIS

Along the Driveway You Will Always Enjoy These Distinctive Color Combinations

\section{Iris Kaempferi-Japanese Iris}

These are magnificent and where they succeed surpass everything. They require well enriched soil and plenty of moisture during the Summer, but standing water should be avoided. The flowers are very large and their delicate colorings are very difficult to describe. They bloom in July after the German Iris. The collection we offer are the best selection from a large collection. They are true to name and free from mixture. Order by number.

1. BANDAI-NO-NAMI-Fine large white. Six petals.

5. Large reddish purple. Six petals. Very at. tractive. Each, $50 \mathrm{c}$

15. USHIO-NO-KOMURI - Delicate blue, shaded darker. Six petals.

47. Large, dark violet. Six petals.

51. Light blue. Very large. Six petals.

65. Light blue. Six petals. Each, 50c

67. White, shaded light blue. Three petals.

69. Very handsome white. Three petals. Each, 50c

Each, 50c

Japanese Iris, except where noted, 35c each; $\$ 3.50$ per dozen

\section{Iris Pumilla}

These are very dwarf, and blossom early before the taller varieties. They are excellent for borders or the rockery.

BRIDE-Very large white.

FORMOSA-S. Deep blue; F. Dark purple.

LUTEA-Golden yellow.

Above three varieties, $35 \mathrm{c}$ each; one of each for $\$ 1.00 ; \$ 3.50$ per dozen 


\section{HARDY PHLOX}

COR brilliant masses of color in the landscape or hardy border, the hardy Phlox ranks F supreme. They bloom from July on, at a time when other flowers in the border are comparatively scarce. A very wide range of colors is possible. During the past few years, some wonderful new varieties have been produced. These have larger panicles of flowers with much larger flowers, and present some new and very brilliant colors.

They may be planted any time in Fall or early Spring. The soil should be well prepared and made very rich for best results. Plant 12 to 15 inches apart and water thoroughly during periods of dry weather. The clumps ought to be divided and replanted in fresh soil at least once in three years.

The following varieties have been carefully selected and represent some of the best in cultivation.

ATHIS-Tall, light salmon, dark eye.

B. COMPTE-Rich burgundy-red. Very large and attractive. Each, 35c

BRIDESMAID - Tall, white, carmine center.

COQUELICOT-Brilliant scarlet with a crimson eye.

ELIZABETH CAMPBELL-Light salmon pink. Very large truss.

Each, 50c

ECLAIREUR - Salmon scariet, clearly defined crimson eye. Medium.

FORDHAM-Pure white, with small red eye. The largest individual flower of any Phlox I know. New.

Each, 50c

FRAU ANTOINE BUCHNER-Enormous trusses of large, pure white florets. Dwarf. The best white.

GENERAL VAN HEUTZ-Brilliant salmon red, with white eye.

Each, 35c

GEO. A. STROHLEIN-Brilliant orange scarlet, carmine eye. Extra large flower and truss. Tall.

Each, 35c

KATHLEEN-Deep salmon pink, with darker center. Individual florets very large; new.

Each, 50c

LA SOLEIL-Light rose, shaded lighter toward the center.

LA VAGUE-Pure mauve, dark eye.

LE MAHDI-Dark bluish violet, extra fine.

MISS LINGARD - An early flowering variety. White, with a faint lilac eye.

MME. P. LANGIER-Brilliant pure crimson. Extra good.

MRS. JENKINS-Pure white. Early.

PANTHEON-Salmon rose. Very large florets. Good pink variety.

RHINELANDER-Handsome salmon pink, large truss and individual florets. Medium dwarf.

RICHARD WALLACE - Pure white, with dark eye.

R. P. STRUTHERS-Bright rosy red, crimson eye. The best of its color.

RIJNSTROM-Beautiful clear pink. Large flower and truss.

TAPIS BLANC-Very large, white florets. Panicles are very large and plant very dwarf.

Each, 35c

THOR-Deep salmon pink, overlaid scarlet, darker eye.

Each, 35c

VON HOCKBURG-Dark crimson. Very large. One of the finest.

Each, 35c

W. C. EGAN-Beautiful soft rose. Florets ex tremely large. Medium. Each, 35c

WIDAR-Attractive violet blue, with a pure white eye.

Each, 35c

Any of the above except as noted, 25c each; $\$ 2.75$ per dozen, prepaid; 25 of a variety for $\$ 5.00$ Strong, field-grown plants

\section{Special Collection of Phlox}

The following ten varieties prepaid for $\$ 2.50$

Two collections, two of each, for $\$ 4.75$

B. Compte

Frau Antoine Buchner

La Vague

Miss Lingard

Pantheon
Rhinelander

Richard Wallace

Rijnstrom

Von Hockburg

Widar

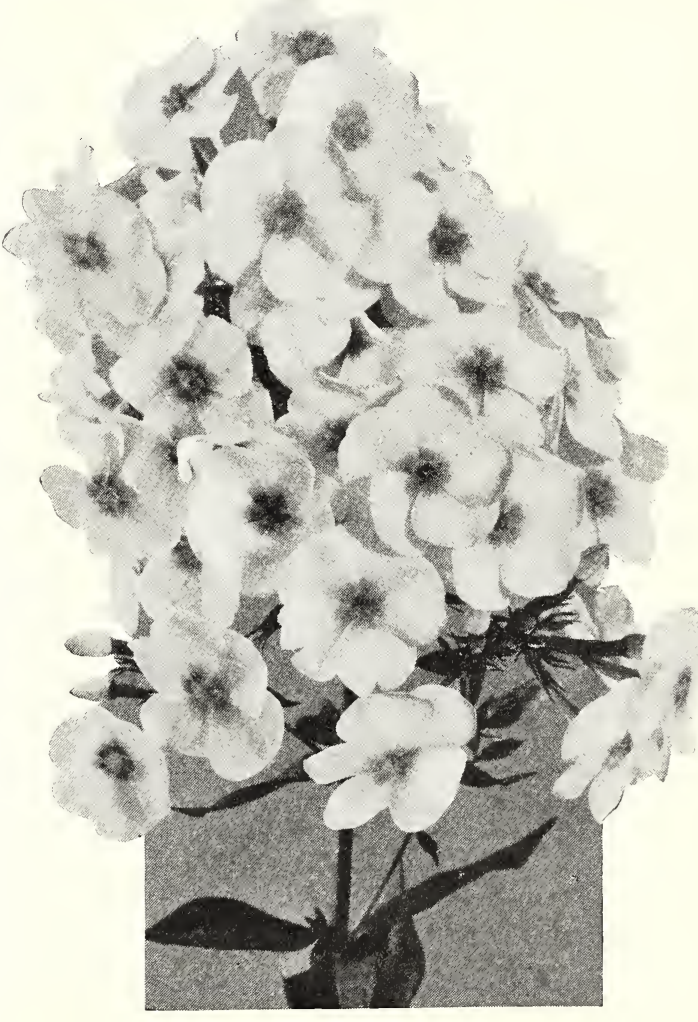

PHLOX - LA VAGUE 


\section{HARDY PLANTS}

7 HE following list embraces the most desirable varieties of hardy perennial plants, suitable for the garden, hardy border or the rockery. They are of easy culture and include many of the handsomest flowers in cultivation. Those particularly well adapted for the rockery are indicated by an *.

Strong, field grown plants, unless noted, $25 \mathrm{c}$ each; $\$ 2.50$ per dozen prepaid. Write for price on larger quantity.

*ACHILLEA MILLEFOLEUM ROSEUM-Finely cut foliage. Dense heads of pink flowers all Summer.

18 in., Each, 30c

ACHILLEA, THE PEARL-Small, double white flowers in July. $1 \mathrm{ft}$.

*ACHILLEA TOMENTOSA-Bright yellow flowers in July. 8 in.

ACONITUM FISHERII - Glossy, deep green foliage. Hooded, deep blue flowers in Fall. Good cut flower. $\quad 18$ in., Each, 35c

* Agrostema CORONARIA (Mullen Pink)Silvery foliage. Rosy crimson flowers June and July. $3 \mathrm{ft}$.

*AJUGA-REPTANS (Bugle Flower)-A very satisfactory creeper, the glossy foliage forming a dense ground cover. Will grow in either sun or shade. Blue flowers in May. Six inches tall.

*ALYSSUM-SAXATILE COMPACTUM - A very desirable border plant. Broad heads of bright yellow flowers in May. $1 \mathrm{ft}$.

ANCHUSA ITALICA (Dropmore Variety)-A rank growing plant, 5 to $6 \mathrm{ft}$. high, covered with bright blue flowers in Summer. Each, 35c

ANEMONE, QUEEN CHARLOTTE - Large, semi-double, silvery pink.

Each, 50c; Doz., $\$ 5.00$

A. WHIRLWIND-Very large, double white.

Each, 50c; Doz., $\$ 5.00$

AQUILEGIA COERULEA (Rocky Mountain Columbine)-White, with blue corolla. Long spurred.

Each, 35c

AQUILEGIA CHRYSANTHA-Golden yellow, long spurred.
MRS. SCOTT ELLIOTT-Long spurred hybrids. The finest mixture.

"ARABIS ALPINA-Completely covers itself with pure white flowers in early Spring. 6 in.

*ARMERIA MARITIMA (Thrift) - Evergreen, grass-like foliage. Pink flowers in May and June. A choice plant for the rockery.

Each, 35c

ARTEMESIA LACTIFLORA-Heads of small white, very fragrant flowers in August.

$3 \mathrm{ft}$. , Each, 35c

ASPHODELLUS LUTEUS (King's Spear) Bright yellow, lily-like flowers in early Spring. Very fragrant, foliage narrow. $2 \mathrm{ft}$., Each 35c

*ASTER ALPINUS (Alpine Aster)-Bluish purple flowers on five-inch stems. Forms fine clusters of ground leaves. An excellent rock or edging plant.

ASTERS (Michelmas Daisies)-

FELTHAM BLUE-Large, clear blue. $4 \mathrm{ft}$.

ST. EGWIN-Clear rose pink, good habit. $3 \frac{1}{2}$ $\mathrm{ft}$.

MRS. F. W. RAYNOR-The nearest red of any hardy Aster. Scarce. Each, 35c

BELLIS PERENNIS (English Daisy)-

SNOWBALL-Double white. Each, 20c LONGFELLOW-Double pink. Each, 20c

BOCCONIA CORDATA (Plume Poppy)-Attractive glaucus foliage. Masses of creamy white flowers in panicles in July and August. $6 \mathrm{ft}$.

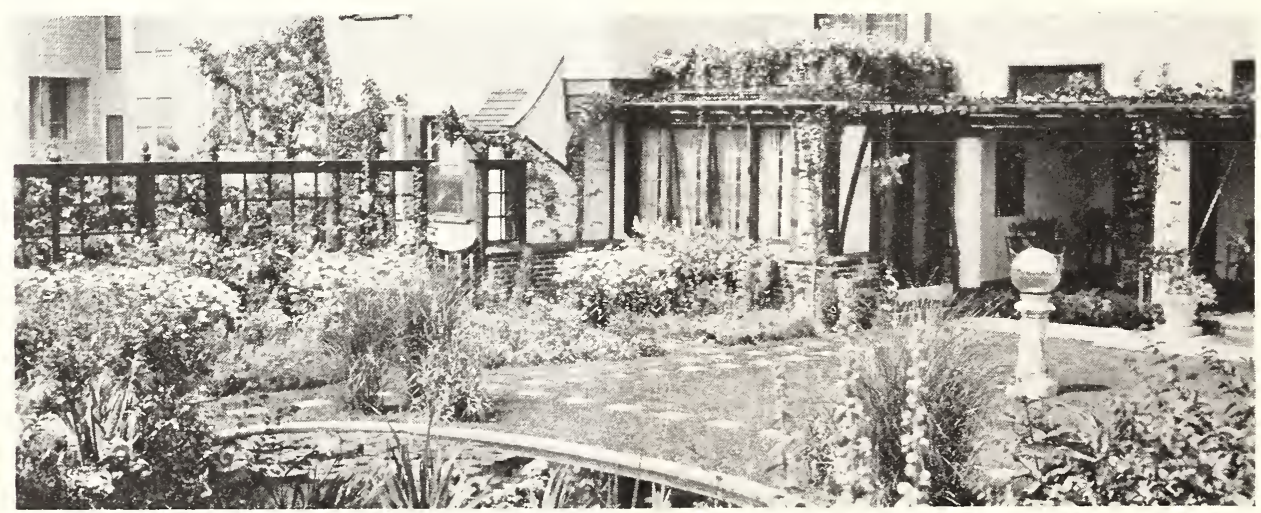

A Charming Garden of Hardy Perennials 


\section{HARDY PLANTS -Continued}

BOLTONIA ASTEROIDES-Pure white, single aster-like flowers. Very free. $4 \mathrm{ft}$.

BUDDLEIA (Butterfly Bush or Summer Lilac)-Long panicles of lilac colored flowers. Very fragrant. Each, 40c

*CAMPANULA CARPATICA (Carpathian Harebell)-A dwarf species producing blue bell-shaped flowers all Summer. 8 in.

CAMPANULA ME D I U M (Canterbury Bells)-Large, cup-shaped flowers, blue, rose or white and mixed.

CAMPANULA PERSICIFOLIA ( $\mathrm{P}$ e a $\mathrm{c}$ Bells)-Handsome spikes of flowers in July and August. Blue or white. $2 \mathrm{ft}$.

C E N T A UR E A MACROCEPHALA Thistle-like golden yellow flowers in July. $3 \mathrm{ft}$.

CENTAUREA MONT A N A (Perennial Cornflower) - Large blue flowers in August. $2 \mathrm{ft}$.

*CERASTIUM TOMENTOSUM-A trailing plant with silvery white foliage and white flowers in abundance.

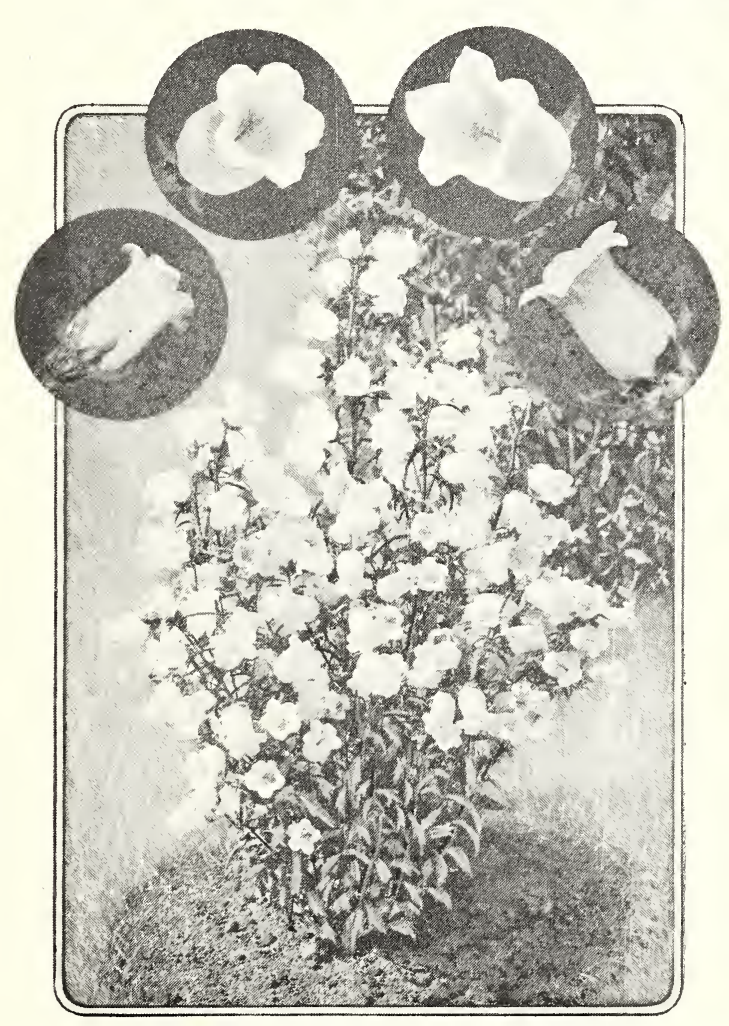

CANTERBURY BELLS-Campanula Medium

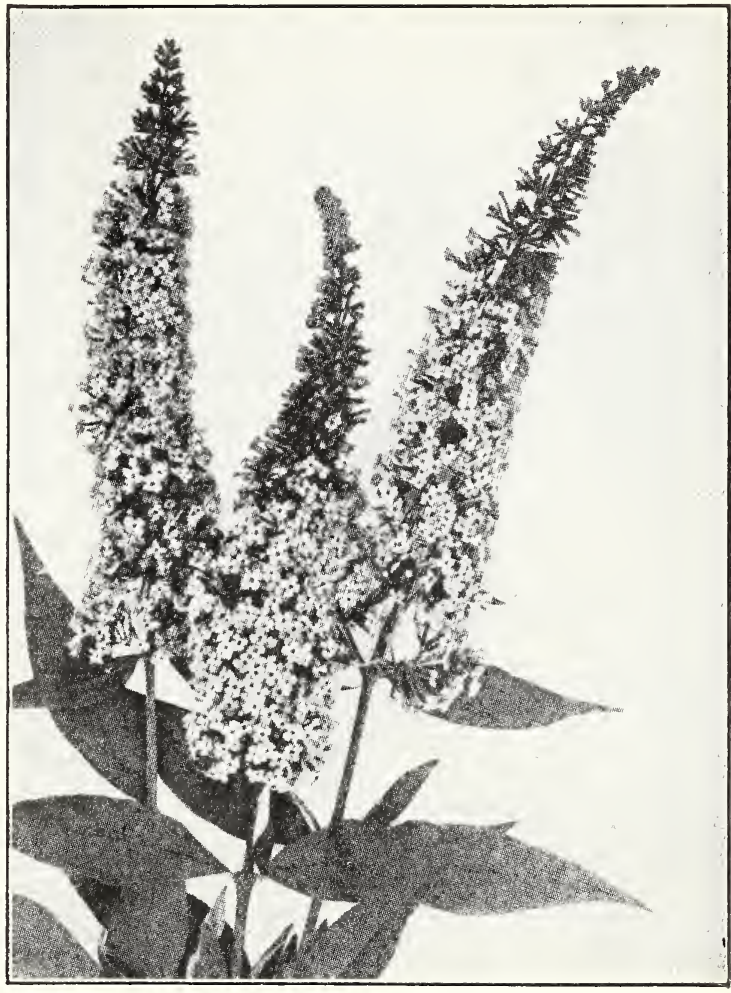

BUTTERFLY BUSH

CHRYSANTHEMUM H A R D Y - Indispensable for late Fall bloom. Should be given rich culture and a sheltered position. fully exposed to the sun for best results. We have found the following quite satisfactory in our climate.

AUTUMN GLOW-Deep pink

EXCELSIOR-Large, yellow.

INDIAN-Red, shaded bronze.

LUCIFER-Dark purplish red.

MARIE ANTOINETTE-Attractive rose color.

NORMANDIE-A very good pink variety. OLD HOMESTEAD-Dark red.

WHITE FLORA-Large pure white.

Above varieties $35 \mathrm{c}$ each; $\$ 3.50$ per dozen

One each of the above eight Chrysanthe. mums, strong, field-grown plants, for $\$ 2.50$ prepaid.

CLEMATIS DAVIDIANA-Deep lavender blue flowers in clusters in August. Very fragrant. Foliage attractive. 3 feet.

Each, 50c

*CONVALLARIA (Lily of the Valley)Well known.

COREOPSIS LANCEOLATA GRANDIFLORA - Rich golden yellow flowers nearly all summer.

DELPHINIUM BELLADONNA HY. BRIDS-Clear turquoise blue flowers. Strong, field-grown roots. 


\section{HARDY PLANTS-Continued}

DELPHINIUM CHINENSE ALBA-A dwa-f species producing spikes of white flowers. 18 in.

DELPHINIUM CHINENSE BLUE-Brilliant, deep blue flowers all Summer. Dwarf.

DELPHINIUM FRENCH HYBRIDS-Grown from the seed of a large collection of named varieties. A wide range of colors in shades of blue. Double and large flowering varieties.

Each, 50c; Doz., $\$ 5.00$

DIANTHUS BARBATUS (Sweet William) Single. All colors mixed.

*DIANTHUS CAESIUS (Cheddar Pink) Compact habit; very sweet, rose colored flowers in May. 6 in.

Each, 35c

DIANTHUS CARYOPHYLLUS (Hardy Carnation)-Double, fragrant flowers all Summer. Excellent for any purpose.

*DIANTHUS DELTOIDES (Maiden Pink) -A dwarf plant producing brilliant crimson flow. ers in June and July.

*DIANTHUS LATIFOLIUS - Bright crimson, double flowers, continuous bloomer.

*DIANTHUS PLUMARIUS - Hardy garden pinks. The old-fashioned fragrant variety. June.

*DICENTRA EXEMIA (Plumy Bleeding Heart) -A dwarf plant having beautiful, finely cut foliage and bright pink flowers throughout the Summer. 10 in.

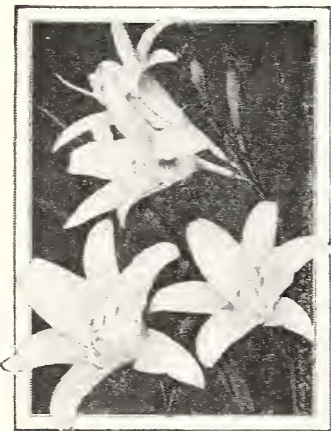

DAY LILY

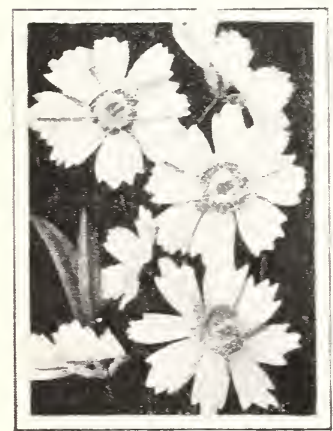

COREOPSIS Each, 35c

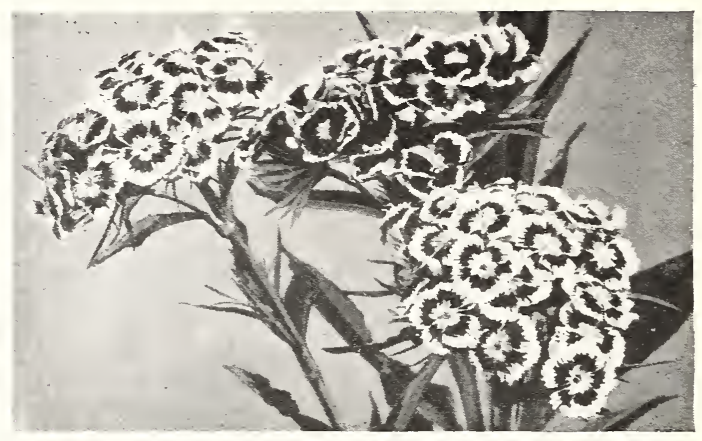

SWEET WILLIAM-Dianthus barbatus

DICENTRA, SPECTABILIS (Bleeding Heart) Long racemes of graceful, pink, heart-shaped flowers. Each, 65c

DICTAMNUS FRAXINELLA (Gas Plant) Rose-pink or white. One of the longest lived plants. The flowers give off a volatile oil which will sometimes ignite if lighted with a match.

Each, $50 \mathrm{c}$

DIGITALIS (Foxglove)-Stately plants bearing long spikes of tubular flowers in July and August. 2 to $3 \mathrm{ft}$.

DIGITALIS NEW SHIRLEY HYBRIDS Taller and larger than the older varieties, also longer lived. New. Each, 35c

DORONICUM CAUCASICUM (Leopard-Bane) - Large, bright yellow, daisy-like flowers in early Spring. Excellent for cutting. Scarce.

Each, 50c

ECHINOPS RITRO (Globe Thistle)-Thistle-like foliage and globular heads of metallic blue flowers which remain attractive for a long time when dried. $2 \mathrm{ft}$.

EPIMEDIUM MACRANTHUM ROSEUM (Bishop's Hat)-Attractive, persistent foliage. Peculiar rosy red flowers. Fine for rockeries.

Each, 35c

EUPHORBIA COROLATTA-A branching, low-growing plant, completely covered with small white flowers in Summer. Very desirable for cutting.

FUNKIA SUBCORDATA GRANDIFLORA (Plantain Day Lily)-Handsome broad foliage and fragrant lily-like flowers in late Summer. $1 \mathrm{ft}$.

Each, 35c; Doz., \$3.50

FUNKIA VARIEGATA-Leaves beautifully variegated with white and green. Fine for edging. Dwarf.

GAILLARDIA GRANDIFLORA-A fine, large flowering strain; brown center, surrounded with crimson rings, and yellow border. Continuously in bloom.

GYPSOPHILA PANICULATA (Baby's Breath) - Mist-like sprays of minute white flowers. Fine for bouquets.

*GYPSOPHILA REPENS-A trailing variety producing clouds of small white flowers in July.

*HELLEBORUS NIGER (Christmas Rose)-Waxy, white flowers appear during mild spells all Winter. Glossy evergreen foliage. Half shade. Scarce.

Each, $\$ 1.50$

HELENIUM RIVERTON GEM-Old gold, changing to red. A very beautiful plant.

Each, 35c 


\section{HARDY PLANTS-Continued}

HELIANTHUS MOLLIS (Hardy Sunflower) -Medium sized yellow blossoms in August. One of the best of the family. $4 \mathrm{ft}$.

HELIOPSIS SCABRA EXCELSA - Golden yellow zinnia-like flowers, useful for cutting. $2 \mathrm{ft}$.

HEMEROCALIS FLAVA (Lemon Day Lily) -Fragrant, golden yellow flowers in large clusters. $2 \mathrm{ft}$.

HEMEROCALIS THUNBERGI - Resembles Flava but blossoms a month later and has the upper end of the flowering stem flattened.

*HEUCHERA BRIZOIDES (Coralbells) Color not so deep as Sanguinea, but stronger in growth and more productive. Each, 35c

*HEUCHERA SANGUINEA-Makes a tuft of heart-shaped glossy green leaves, from which the flowering stems rise a foot or more in height. Flowers small, bright red.

Each, 35c

HESPERIS MATRONALIS (Sweet Rockets)Fragrant, rosy lilac flowers.

HIBISCUS-New Giant flowering Marshmallow, or Mallow Marvels. Flowers sometimes 9 in. in diameter. Very hardy. 5 to $8 \mathrm{ft}$. Separate colors, red, pink and white.

HOLLYHOCKS - Too well known to require description. Double. Red, white, rose, yellow.

HYACINTHUS CANDICANS-A bulbous plant, sending up stalks three feet high, loaded with pendent, creamy white flowers. Blooms con. tinuously all Summer. $\quad 3 \mathrm{ft}$., Doz., $\$ 2.00$

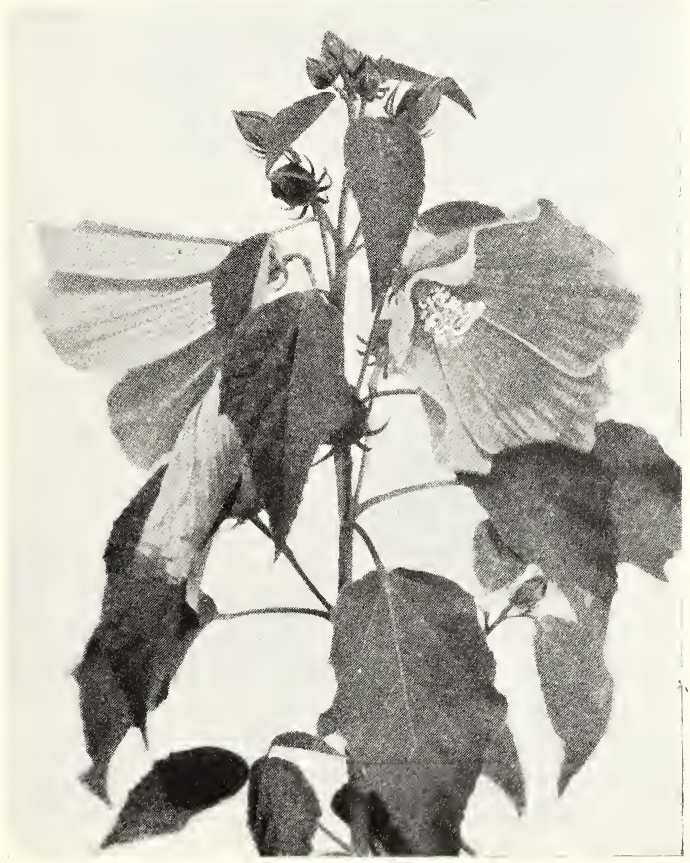

HIBISCUS

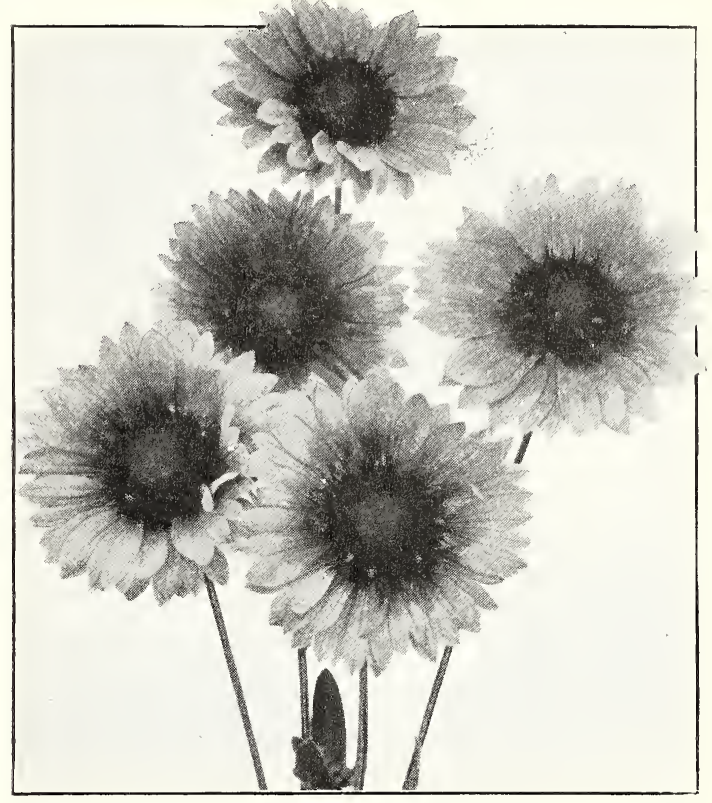

GAILLARDIA

*IBERIS SEMPERVIRENS-White flowers in large heads in May. Attractive evergreen foliage. 10 in., Each, 35c

LATHYRUS LATIFOLIUS-See vines and creepers below.

LAVANDULA VERA (Sweet Lavender)-Fragrant, blue flowers in July and August. $11 / 2 \mathrm{ft}$.

*LEONTOPODIUM ALPINUM (Edelweiss) -White, wooly foliage and heads of small, yellow flowers in June. A first-class rock plant.

4 in., Each, 50c

*LIATRIS PYCNOSTACHYA (Kansas Gay Feather)-Flowers purple, in dense spikes, 4 to $5 \mathrm{ft}$. high. Thick, grass-like foliage. Very choice.

Each, 35c

LILIUMS-No garden is complete without Lilies. Many of the most beautiful varieties are very easy to manage if a few cultural directions are observed. The varieties offered below thrive best in a partially shaded position, except that Candidum requires full sun. Perfect drainage is essential. Plant the bulbs 6 to 8 inches deep. They should be mulched during the Winter, otherwise frost might destroy the bulbs in the ground.

Fall planting is usually recommended. However, some of the Japanese varieties do not arrive from foreign sources before the ground freezes and are successfully planted out in early Spring. A few other varieties can also be successfully planted out in Spring. We offer only a few of the best and more easily grown varieties. 


\section{HARDY PLANTS-Continued}

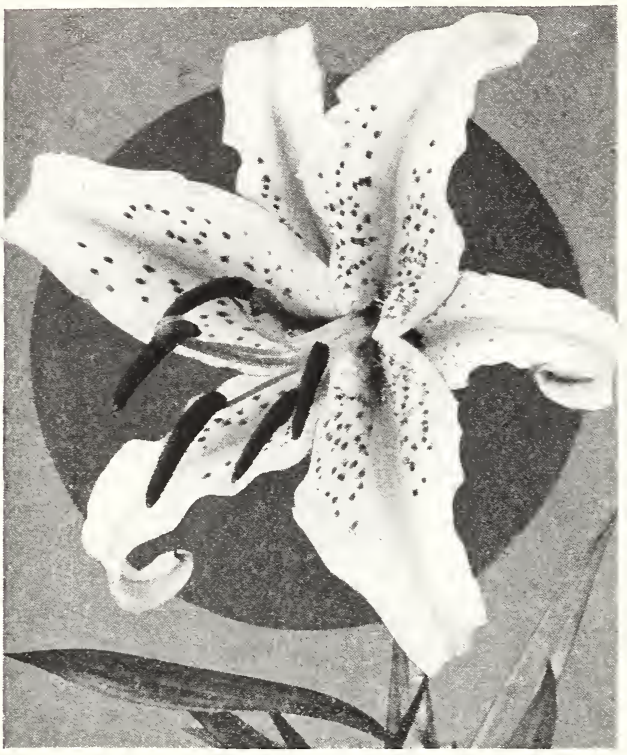

LILY AURATUM

AURATUM (Gold Banded Lily of Japan)-The most popular garden Lily grown. Flowers 8 to 10 inches wide; white spotted purple and gold band through the center of each petal. Fifteen or more fragrant flowers to a plant. Has the longest blooming period of any Lily. August. Large bulbs.

Each, 50c

BATEMANI-Reddish orange. $2 \mathrm{ft}$. August.

Each, 50c

REGALE (The Regal Lily)-Spikes of medium height, bearing several large, fragrant blooms on a stem. White with yellow center, shaded rose on outside of petals. Early July. One of the very best hardy Lilies.

Each, 75c

SPECIOSUM ALBUM-Speciosum Lilies are the most easily grown of the Japanese Lilies. This is the white variety. August. Each, 50c

SPECIOSUM MELPOMENE-Red, with crimson markings. Very attractive color. Large bulbs. Each, 50c

SPECIOSUM RUBRUM-Red on white ground. Large bulbs. Each, 50c

LILIUM TIGRINUM SPLENDENS (Tiger Lily) - Large bulbs. Each, 35c

*LINARIA CYMBALARIA (Kenilworth Ivy)A neat, trailing plant, flowers lavender purple. A very desirable rock plant.

LINUM PERENNE (Flax)-Produces masses of small azure blue flowers in July and August. 18 in.

LOBELIA CARDINALIS-Spikes of intense scarlet flowers. $4 \mathrm{ft}$. Very brilliant.

LUPINUS (Lupine)-Long spikes of pea-shaped flowers on long stems. Attractive colors, blue, rose or white. $3 \mathrm{ft}$.

LYCHNIS CHALCEDONICA - Bright scarlet flowers in heads. Has a long blooming period.
*LYCHNIS VISCARIA SPLENDENS-A choice border or rock plant; bright red flowers in June. 8 in.

LYSIMACHIA CLETHROIDES (Loosestrife)Long, recurved spikes of pure white flowers during late Summer.

$2 \mathrm{ft}$., Each, 35c

*LYSIMACHIA NUMULARIA (C r e e p ing Jenny)-A trailing plant. Will grow in dense shade where other plants fail.

LYTHRUM ROSEUM (Loosestripe) - Produces long spikes of rose-colored flowers from July to September. $4 \mathrm{ft}$.

MONARDA DIDYMA (Cambridge Scarlet) Heads of brilliant scarlet flowers in July and August. $3 \mathrm{ft}$.

*MONTBRETIA - A bulbous plant, throwing numerous spikes of flowers, yellow through orange to red. Hardy with protection.

CROCUSMIFLORA-Orange yellow, tinted red. Doz., $\$ 1.00$

*MYOSOTIS PALUSTRIS (Forget-Me-Not)-A dwarf plant producing small, dark blue flowers in profusion.

NATIVE WILD FLOWERS-We are in touch with collectors in various parts of the country and can supply collected plants of native ferns and other hardy plants at reasonable prices.

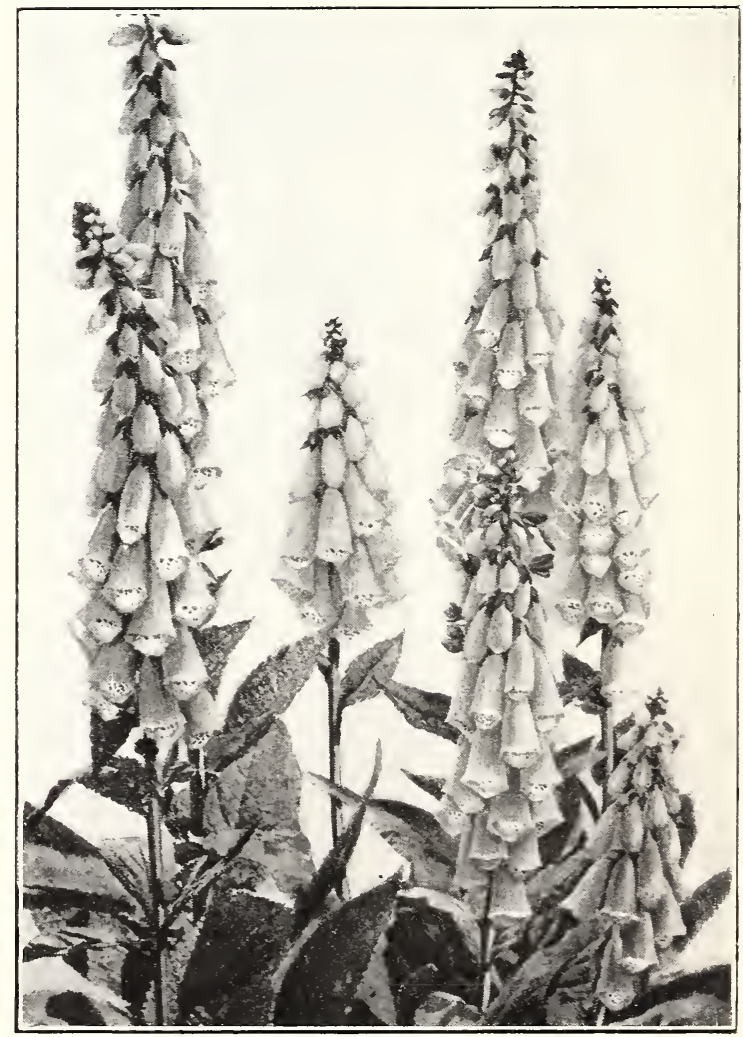

DIGITALIS

Are Unsurpassed for Stately and Picturesque Beauty 


\section{HARDY PLANTS-Continued}

*NIEREMBERGIA RIVULARIS-An attractive trailing plant, producing white, cup-shaped flowers.

OENOTHERA MISSOURIENSIS (E v e $n$ i $n g$ Primrose) - Large, golden yellow flowers in June. Profuse bloomer. 10 in.

PACHYSANDRA TERM IN A L I S (Japan Spurge)-An evergreen trailing plant, growing about 8 in. high. Will grow in dense shade under evergreens or in the open. Plant four inches apart. Special prices for large quantity.

PAPAVER NUDICALE (Iceland Poppy)-Forms a tuft of neat, fern-like foliage from which are produced several slender stems crowned with the attractive cup-shaped flowers. Orange, yellow or white.

Each, 35c

PENTSTEMON BARBATUS TORREYI (Beard Tongue)-Bright scarlet flowers on tall spikes all Summer.

*PHLOX SUBULATA (Moss Pink)-A dwarf variety having evergreen moss-like foliage, completely covered with flowers in early Spring. Rose or white.

PHYSALIS FR A N C H T I (Chinese Lantern Plant)-Very large orange red fruits, suitable for Winter decorations.

PHYSOSTEGIA (False Dragonhead)VIRGINICA-Spikes of delicate pink tubular flowers. 3 to $4 \mathrm{ft}$. high.

*PLATYCODON (Balloon Flower)-Large bell. shaped flowers. August to September. Blue or white.

*PLUMBAGO LARPENTAE (Leadwort)-Deep blue; late Summer. Attractive foliage of dwarf, spreading habit. Excellent for the border or rockery. 6 in.

*POLEMONIUM REPTANS-Blue. Has very attractive, fern-like foliage. 8 in.

*POTENTILla (Cinquefoil)-Dull reddish purple and scarlet blossoms are freely produced. A very attractive dwarf plant. $1 \mathrm{ft}$.

PYRETHRUM ROSEUM-Finely cut foliage and daisy-like flowers on long stems, early in the season. Mixed colors.

*PRIMULA POLYANTHUS-A choice border plant. Assorted colors.

*RANUNCULUS REPENS FI. PI. (Double Buttercup)-Bright golden yellow flowers in profusion. Low, spreading growth. 10 in. May.

RUDEBEKIA LACINATA (Golden Glow) -Golden yellow, produced in profusion. $6 \mathrm{ft}$.

RUDEBEKIA-NEWMANI-Single, daisylike flowers, orange yellow with brown cone. $2 \mathrm{ft}$.

RUDEBEKIA-PURPUREA-Large reddish purple flowers, with prominent dark cone.

SALVIA AZUREA GRANDIFLORA (Meadow Sage)-Pretty spikes of pale blue flowers in August and September. Profuse bloomer. $3 \mathrm{ft}$.
*SANTOLINA INCANA (Lavender Cotton)Flowers not valuable. One of the best dwarf evergreen plants in cultivation. Foliage silvery white; aromatic. $1 \mathrm{ft}$.

"SAPONARIA OCYMOIDES - A very pretty trailing plant for the rockery or border. Rose pink blossoms.

*SAXIFRAGA CORDIFOLIA - Pink flowers. Very early in Spring. Handsome broad, deep green foliage which is always attractive.

$1 \mathrm{ft}$. , Each, 50c

SCABIOSA CAUCASICA (Blue Bonnet) - Soft, clear lavender-blue flowers all summer.

2 ft., Each, 35c

SEDIUM (Stonecroft)-

*ACRE (Golden Moss)-Flowers bright yellow, foliage green. Excellent ground cover. Very dwarf.

"ALBUM-Very dwarf green foliage, white flowers.

"KAMCHATICUM-Attractive green foliage, turning yellow in fall. Flowers orange.

Each, 35c

OPPOSITIFOLIUM-Attractive, succulent foliage, light pink blossoms. 5 in.

*SPURIUM COCCINEUM - Rosy crimson, handsome foliage. 4 in.

SPECTABILE-The best Sedum, large heads of pink flowers. August.

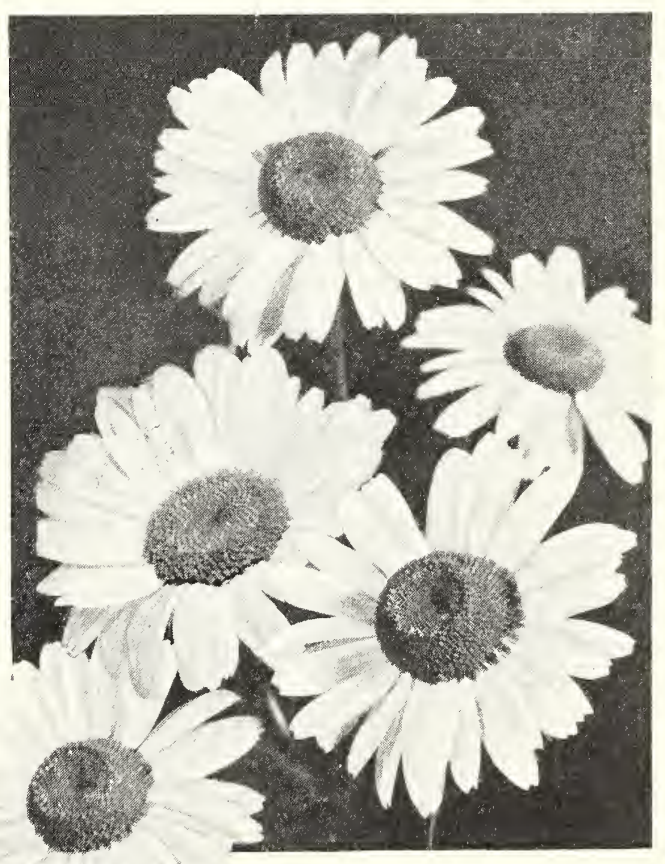

SHASTA DAISY 


\section{HARDY PLANTS-Continued}

\section{*SEMPERVIVUM (House Leek) -}

ARACHNOIDEUM-Forms a rosette of thick leaves connected by silvery threads. Bright red.

FIMBRIATUM-Leaves tipped with a tuft of hairs. Bright red.

TECTORUM-Broad leaves, tipped brown. Light red.

SHASTA DAISY - Large, snow white flowers throughout the Fall. Splendid for cutting.

SPIREA GRANDIS ROSEA MAXIMA-Creamy white flowers on drooping stem. Spikes $2 \mathrm{ft}$. long. $5 \mathrm{ft}$. A beautiful plant. Each, 50c

SPIREA FILIPENDULA Fl. P1. - Clusters of double white flowers in June and July. Handsome evergreen fern-like foliage. A very choice hardy plant.

12 in., Each, 50c

SPIREA JAPONICA (Queen Alexandra)-Soft, delicate pink, feathery plumes. Each, 50c

SPIREA JAPONICA (Gladstone)-Similar to the above but pure white.

Each, 50c

SPIREA PALMATA ELEGANS (Meadow Sweet) -Light pink flowers in handsome plumes. $3 \mathrm{ft}$.

SPIREA ULMARIA Fl. Pl.-Similar to the preceding but has double, creamy white flowers. Fine for cutting.

Each, 35c

*STATICE LATIFOLIA (Sea Lavender)-Small, lavender blue flowers in immense heads, useful for dried bouquets. Foliage bright green, thick and leathery. $1 \frac{1}{2} \mathrm{ft}$.

"STOKESIA CYANEA (Cornflower Aster) Light blue, Centaurea-like blossoms throughout the late Summer.

TRADESCANTIA VIRGINICA (Spiderwort)Blue flowers. A free and continuous bloomer. $2 \mathrm{ft}$.

TRITOMA, PFITZERI (Red Hot Poker)-Long spikes of orange scarlet flowers, continuously from August to November. Very ornamental.

$3 \mathrm{ft}$., Each, 35c

TROLLIUS EUROPEUS (Globe Flower)-Giant yellow Buttercup-like blossoms nearly all Summer. A choice plant, preferring a moist situa. tion.

Each, $50 c$

*TUNICA SAXIFRAGA - A handsome dwarf tufted plant, bearing a profusion of small pink flowers through late Summer. Good for edging or rockery.

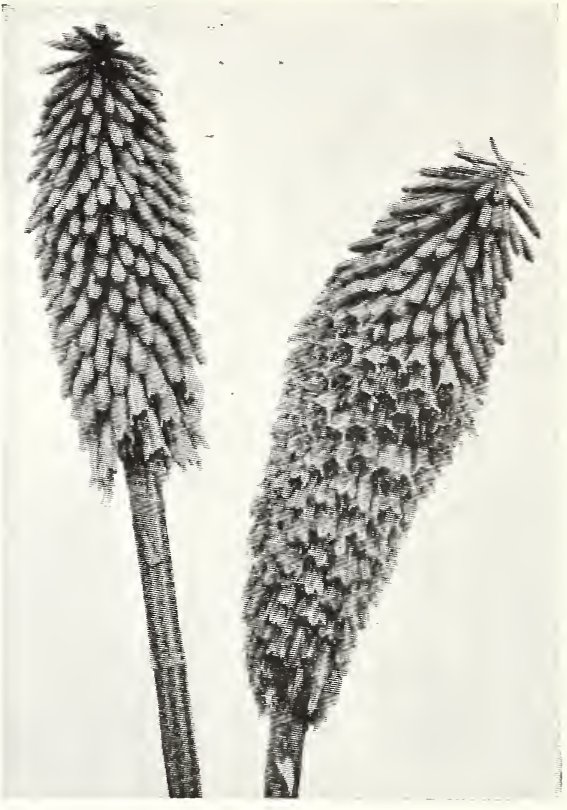

TRITOMA PFITZERI-Red Hot Poker

VALERIANA OFFICINALIS (Hardy Garden Heliotrope)-Showy heads of lavender white flowers. June. Deliciously fragrant.

3 ft., Each, 35c

*VERONICA AMETHYSTINA-Amethyst blue. Trailing habit. 10 in. June. Each, 35c

*VERONICA INCANA - Bright blue. July. Light grey foliage. Always has a good ap. pearance. $12 \mathrm{in.}$

VERONICA LONGIFOLIA SUBSESSILIS Pretty spikes of blue flowers in late Summer. A very choice blue flowering plant. $2 \mathrm{ft}$., Each, 35c

VERONICA SPICATA - Long spikes of violet blue flowers. $1 \frac{1}{2} \mathrm{ft}$. July.

VINCA MINOR (Trailing Myrtle)-Glossy, green foliage. Useful ground cover for shady places. Evergreen.

*VIOLA CORNUTA (Tufted Pansies)-Mixed colors. Perennial and blooms continuously through the Summer. $100, \$ 10.00$

"VIOLA ODORATA (Sweet Violet)-Gov. Herrick. Deep purple. This variety blooms freely, is sweetly scented and perfectly hardy.

YUCCA FILAMENTOSA (Adam's Needle) Very stately both in foliage and flower. Creamy white.

$3 \mathrm{ft}$., Each, 35c

\section{HARDY GRASSES}

EULALIA, GRACELIMA UNIVITTATA-Very handsome narrow foliage; bright green with a white mid-rib.

$6 \mathrm{ft}$., Each, 35c

*FESTUCA GLAUCA (Blue Fescue Grass)-Forms dense tufts of narrow bluish leaves. 12 in. Very ornamental as an edging. Each, 25c
JAPONICA ZEBRINA - Broad green foliage, with broad yellow band across the leaves.

7 ft., Each, 35c

JAPONICA VARIEGATA-Broad green foliage, striped yellow.
$5 \mathrm{ft} .$, Each, 35c 


\section{EASY - TO - MAKE PERENNIAL GARDENS}

7 HE planting of a perennial garden is very simple; once planted these perennials bloom gaily year after year, prospering with little or no attention. Radiant in their bright color combinations,

fascinating in form and detail, we suggest common-sense perennial beds that anyone can easily follow, either as a single bed or a combination as shown in the smaller illustration.

The number of perennials under each offer covers the required number for a single perennial bed-if additional beds are required, two, three or four, order additional offers. For larger beds, two or more of each item may be planted in a colony.

\section{OFFER No. 190}

(14 Perennials)

\section{$\$ 2.95$}

$\begin{aligned} \text { A-1 } & \text { Hollyhock } \\ \text { B-1 } & \text { Delphinium } \\ \text { C-1 } & \text { Foxglove } \\ \text { D-1 } & \text { Coreopsis } \\ \text { E-1 } & \text { Phlox, White } \\ \text { F-1 } & \text { Yellow Day Lily } \\ \text { G-1 } & \text { Aconitum } \\ \text { H-1 } & \text { Shasta Daisy } \\ \text { I-1 } & \text { Columbine } \\ \text { J-1 } & \text { Sweet William } \\ \text { K-1 } & \text { Valeriana } \\ \text { L-1 } & \text { German Iris-Purple } \\ \text { M-1 } & \text { Gaillardia } \\ \text { N-1 } & \text { German Iris-Bronze }\end{aligned}$

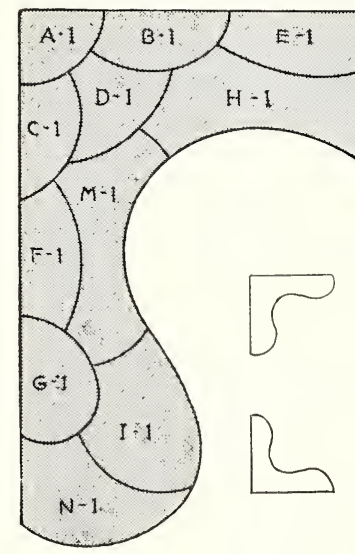

\section{OFFER No. 191}

(30 Perennials)

\section{$\$ 6.90$}
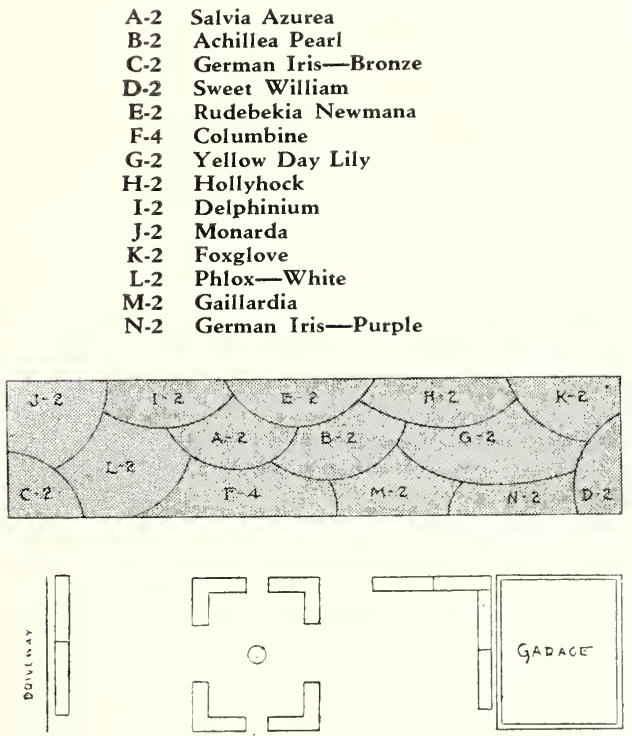

PLAN No. 191

6 feet $\times 2$ feet

Suggesting three combinations using Plan No. 191

OFFER No. 192

(40 Perennials)

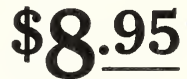

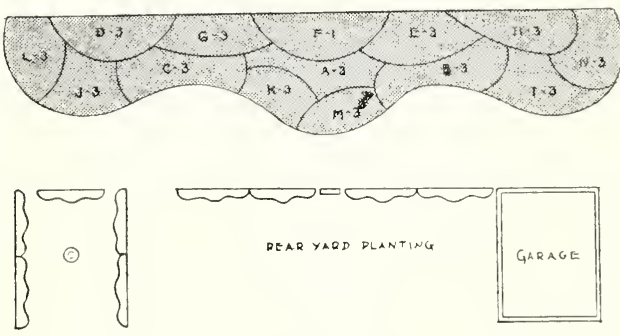

PLAN No. 192

8 feet $\times 2$ feet overall 


\section{Roses}

\section{Queen of all Flowers}

$\mathrm{T}$ HIS year we are offering a few of the best and most popular garden roses to our patrons. The list we offer has been very carefully selected and contains only those varieties which are hardy and free bloomers. They are best planted in the Spring, as soon as the ground is dry enough to work. The ground should be thoroughly and deeply prepared with a heavy application of well rotted manure, that from the cow stable being the best. A heavy, well drained loam soil suits them best. Set the plants at least two feet apart. If on their own roots, plant a little deeper than they stood in the nursery row, budded plants should be planted with the union of the bud and stock about two inches below the surface of the soil. Immediately after planting thin them out to three or four shoots and cut these back to within four inches of the ground. During the growing season keep the surface soil loose with the hoe and water occasionally during extended droughts. A top dressing of bone meal at intervals during the Summer will be found very beneficial. Except as noted, rose bushes will be sent by express.

\section{Select Hardy Everblooming Hybrid Tea Roses}

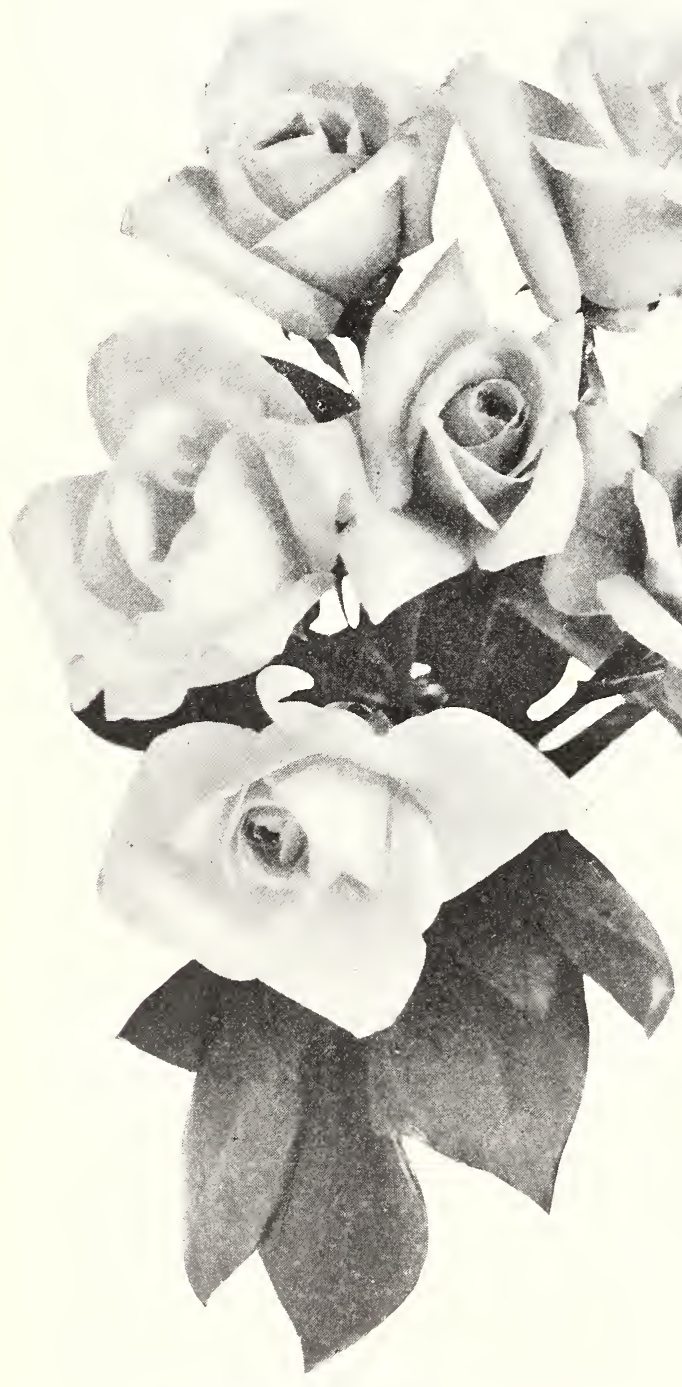

EVERBLOOMING HYBRID TEA ROSES
COLUMBIA-A most pleasing shade of rose pink. Sweetly perfumed. Good size, perfectly formed bud.

FRANCIS SCOTT KEY-Rich red. Very large bloom. Strong growth. Good in Autumn.

GOLDEN EMBLEM-Clear yellow, sometimes streaked with red on outer petals. Makes a most beautiful bud.

Each, $\$ 1.50$

GORGEOUS - Amber yellow, veined reddish copper. Large and full. Good habit.

GRUSS AN TEPLITZ-Rich scarlet, shaded crimson. Very fragrant. One of the very best garden roses.

HADLEY-Rich crimson with deeper shades. Intensely fragrant and a continuous bloomer. The best red rose for the garden.

HOOSIER BEAUTY - Dazzling crimson scarlet. Beau. tiful, long pointed bud, very sweet. One of the best.

Each, $\$ 1.00$

JONKHEER J. L. MOCK - Inside of petals deep pink, outside silvery rose. Very striking. A strong grower and free bloomer.

JULIET-Inside of petals rich rosy red, outside old gold. Large and very full. A handsome flower.

KAISERIN AUGUSTA VICTORIA-Soft, creamy white. Large, full, beautiful in bud form. Very fragrant.

LOS ANGELES-Luminous flame pink, shaded coral and translucent gold at base of petals. Buds are long and pointed and flowers very large. Sweetly fragrant. Strong, healthy grower. One of the finest garden roses. $\quad$ Each, $\$ 1.00$

MME. EDWARD HERRIOT-The Daily Mail Rose. Coral red, shaded yellow and scarlet. Attractive color. Beautiful bud. Semi-double. Medium size. MRS. AARON WARD--Indian yellow, shaded lighter toward the edges of the petals. Splendid form and a free bloomer. Very satisfactory. 
OPHELIA - Delicate salmon-flesh shaded rose. The large buds, perfect in form, are freely pro. duced. One of the best.

RADIANCE-Brilliant carmine pink, shaded salmon and yellow at base of petals. Large and free.

SUNBURST-Rich yellow, shaded coppery or ange. Long pointed bud and a free bloomer.

SOUVENIR DE CLAUDIUS PERNET-Bright sunflower yellow, does not fade. Long pointed buds on good stems. Foliage bright, glossy green. The best yellow rose. New. Each, $\$ 1.50$

SOUVENIR DE GEORGES PERNET-Intense oriental red, shaded cochineal and suffused yellow. Large, beautiful bud. Free bloomer.

Each, $\$ 1.00$

Above Roses first-class, field-grown plants. Each, $75 \mathrm{c} ; \$ 8.00$ per dozen except as noted.

\section{Special}

One each of the above eighteen hybrid tea roses sent prepaid for $\$ 14.25$.

\section{Six Popular Hybrid Perpetual Roses}

FRAU KARL DRUSCHKI-Pure white, perfect form, free bloomer. The best hardy white rose.

HUGH DICKSON-Intense crimson, shaded scarlet. Fragrant, large and full.

J. B. CLARK-Deep scarlet, shaded crimson. Very large. Vigorous growth.

MARSHALL P. WILDER-Rich, glowing red. Large and full. Very free.

MRS. JOHN LAING-Soft pink. Free bloomer Fragrant. One of the best pink garden roses.

PRINCE CAMILLE DE ROHAN-Dark crimson maroon, shaded scarlet. The best very dark rose.

Above six Roses, each, 75c; dozen, $\$ 8.00 ; 6$ of a variety at dozen rate.

SPECIAL-One each of the above six Roses for $\$ 4.00$

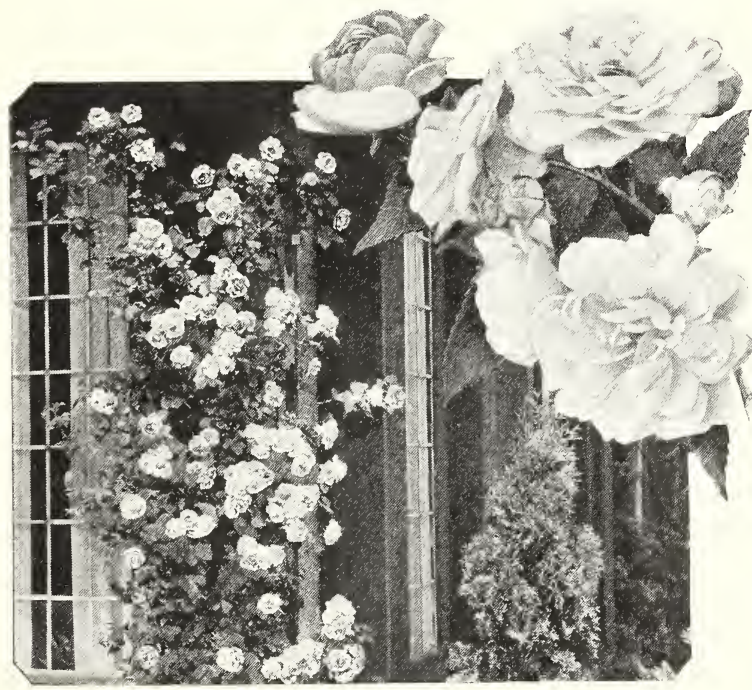

PAUL'S SCARLET CLIMBER

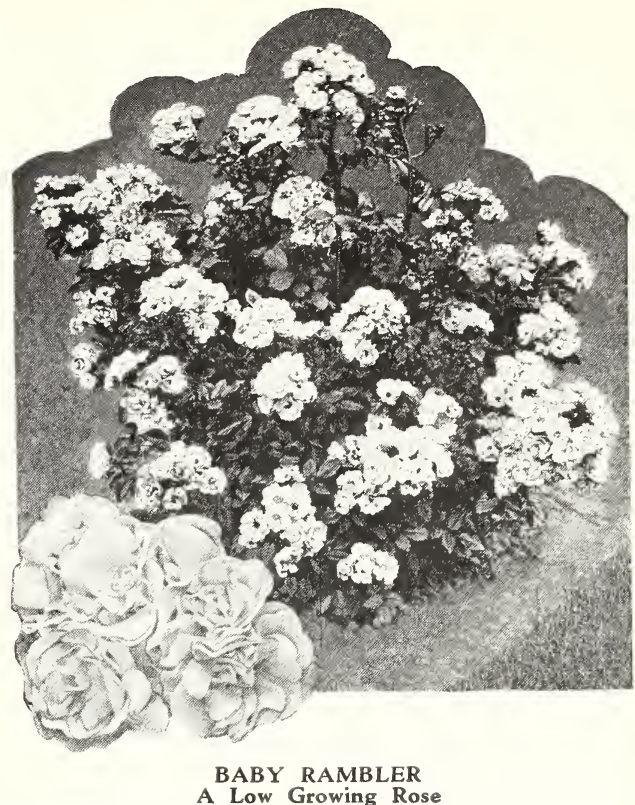

A Bed of Baby Ramblers is a Sight Not Easily Forgotten

\section{Dwarf or Baby Roses}

BABY RAMBLER-Rosy crimson. Very free. Makes a fine hedge.

Each, $\$ 1.00$

BABY DOROTHY - Similar to the above but of a deep pink color.

Each, $\$ 1.00$

CECIL BRUNNER-Sof t rosy pink on a creamy white ground. Small, long pointed buds of perfect form. Also called "Sweetheart Rose."

Each, $\$ 1.00$

SPECIAL-One each of the above three Roses for $\$ 2.50$

\section{Hardy Climbing and Rambler Roses}

AMERICAN PILLAR-Produces immense clusters of single Roses, individual flowers are very large, pink with white center and cluster of golden anthers. Very satisfactory.

Each, 75c

CLIMBING AMERICAN BEAUTY - A rich deep rose pink of good form. Strong grower and free bloomer. Each, 75c

DOROTHY PERKINS-Soft pink. Blooms profusely in large clusters. The best pink rambler.

Each, 50c

EXCELSA - Deep crimson. Similar to Dorothy Perkins in foliage and habit of growth. Does not fade. Each, 50c

PAUL'S SCARLET CLIMBER - Bright scarlet, shaded crimson. Semi-double flowers in large clusters. Does not fade; new.

Each, 75c

SILVER MOON - Pure white. Semidouble flowers over four inches in diameter.

Each, $75 c$

SOURCE D'OR-Large, double yellow flow. ers. The best hardy yellow climbing rose. Each, $75 c$ 


\section{HARDY VINES}

$\mathrm{N}$

OTHING lends such a pleasing effect to wall or veranda as the judicious use of vines. The hardy vine is best adapted for covering an unsightly wall or for furnishing shade and ornament to verandas. With the advent of spring the tendrils are given new life and as the season advances they soon become a beautiful covering. Hardy vines practically take care of themselves after once established, and are much more desirable and less trouble than the annual or tender varieties. Without climbing vines many beautiful homes would present a sad picture during the hot summer. Vines are sent by express.

AMPELOPSIS VEITCHI (Boston Ivy)-The best vine for covering stone or brick work, to which it clings tenaciously. Each, 75c

ARISTOLOCHIA SIPHO (Dutchman's Pipe) Large, broad, light green leaves. A rapid grower and justly popular. Each, $\$ 1.00$

BIGNONIA GRANDIFLORA ( $\mathrm{T} \mathrm{r} \mathrm{um} \mathrm{p} e \mathrm{t}$ Vine)-Very attractive orange-red trumpetshaped flower. The true flowering variety.

Each, $\$ 1.50$

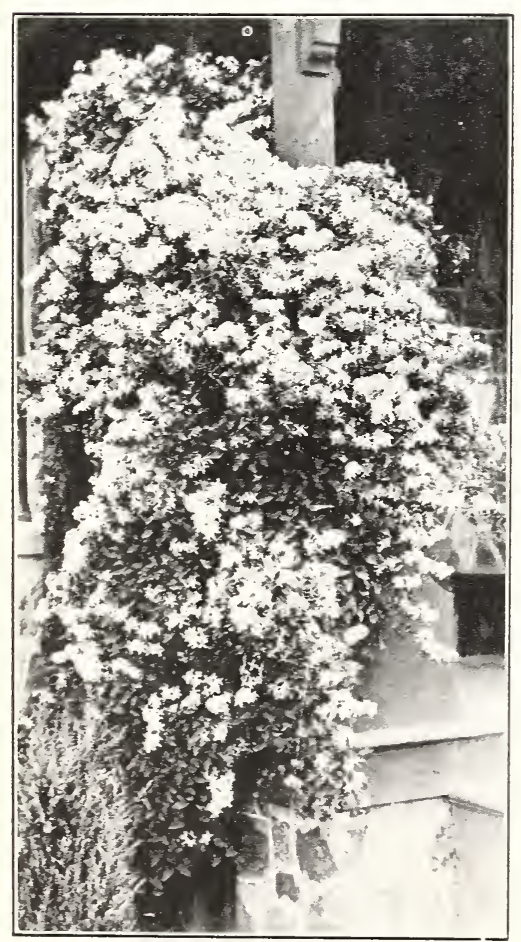

CLEMATIS PANICULATA

One of the Finest Porch Vines. Its Mass of Beautiful White Flowers in Autumn Almost Hide the Vine and Always $W$ in Admiration

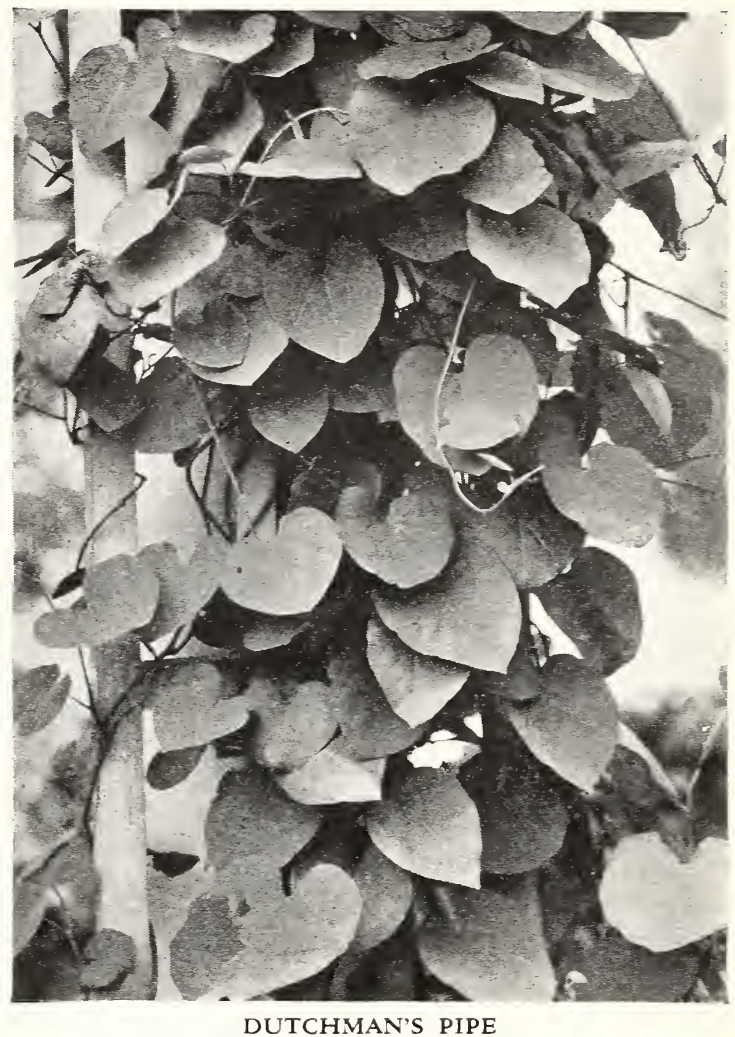

Gives Densest Shade and Also Protection from Rain Because of the Overlapping of its Large Leaves

CELASTRUS SCANDENS (Bitter Sweet)-A native vine: yellow flowers, followed by orange colored fruit which remains on the plant during Winter. Will thrive in shade. Each, $50 \tau$

CLEMATIS PANICULATA-Fragrant, white flowers in August, beautiful foliage and a rapid, vigorous grower.

Each, $50 \mathrm{c}$

CLEMATIS HENRYI-Large, cream white flowers, similar to Jackmanni except in color.

Each, $\$ 1.00$

CLEMATIS JACKMANNI-Large, deep purple flowers. Very strong.

Each, $\$ 1.00$

EUONYMUS RADICANS VEGETUS - Large, glossy deep green foliage, evergreen and hardy. Produces orange red berries which remain on plant nearly all Winter. One of the best evergreen trailers for our climate.

2 year, Each, 53c

LATHYRUS (Everlasting Pea)-A hardy herbaceous plant, producing clusters of rose-colored, pea-shaped blossoms.

Each, 35c

POLYGONIUM AUBERTI (Silver Lace Vine)-A strong growing vine, attains a height of $25 \mathrm{ft}$. Throughout the Summer and Fall it is completely covered with foamy sprays of white flowers. A very desirable vine not as well known as it should be.

Each, $\$ 1.00$

WISTERIA CHINESE PURPLE-Produces large masses of blue flowers in May. A vigorous grower and very desirable.

Each, $\$ 1.00$ 


\section{Hardy Shrubs and Hedge Plants}

$\mathrm{D}$ URING April and May we can supply strong, healthy, young plants of the popular varieties of ornamental and flowering shrubs. Let us quote on your requirements. We will gladly quote special prices where plants are required in large quantity for extensive plantings. Shrubs will be sent by express.

ALMOND, DOUBLE FLOWERING - A dwarf shrub literally covered with pink flowers in May. Each, $\$ 1.00$

ALTHEA (Rose of Sharon)-A tall, upright shrub, flowering late in season. Double, pink, red or white.

2-3 ft., Each, 50c

BARBERRY THUNBERGI (Japanese Barberry) -A dense, hardy, low growing shrub having small leaves and thorny branches. Leaves turn brilliant orange red in Autumn. Bright red berries remain on the plants all Winter. Excellent for low hedges or base plantings.

$12-18$ in.

Dozen, \$2.00; 100, \$12.00

18-24 in., heavy

Dozen, 2.50; 100, 15.00

DEUTZIA GRACILIS - A dwarf, s le n d e r branched shrub. Showy white flowers in long racemes.

$12-18$ in., Each, 75c

DEUTZIA SCABRA (Pride of Rochester) - Of stronger growth than the above. Pink buds and double white flowers. $2-3 \mathrm{ft}$., Each, 50c

FORSYTHIA SUSPENSA FORTUNEI-Golden yellow flowers very early in Spring before the leaves appear. One of the first shrubs to blossom.

2.3 ft., Each, 75c

HYDRANGEA ARBORESCENS GR A N D IFLORA (Snowball Hydrangea) - Snow white clusters of flowers in Mid-summer. Very showy.

2-3 ft., Each, \$1.00

HYDRANGEA PANICULATA GRANDIFLORA - The best hardy hydrangea. Large clusters of white flowers in August. These change to pink and remain on the plant until Winter.

2.3 ft., Each, $\$ 1.00$

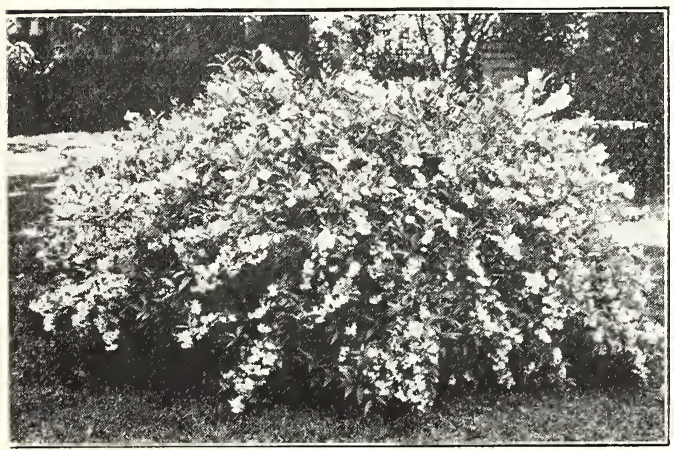

DEUTZIA GRACILIS

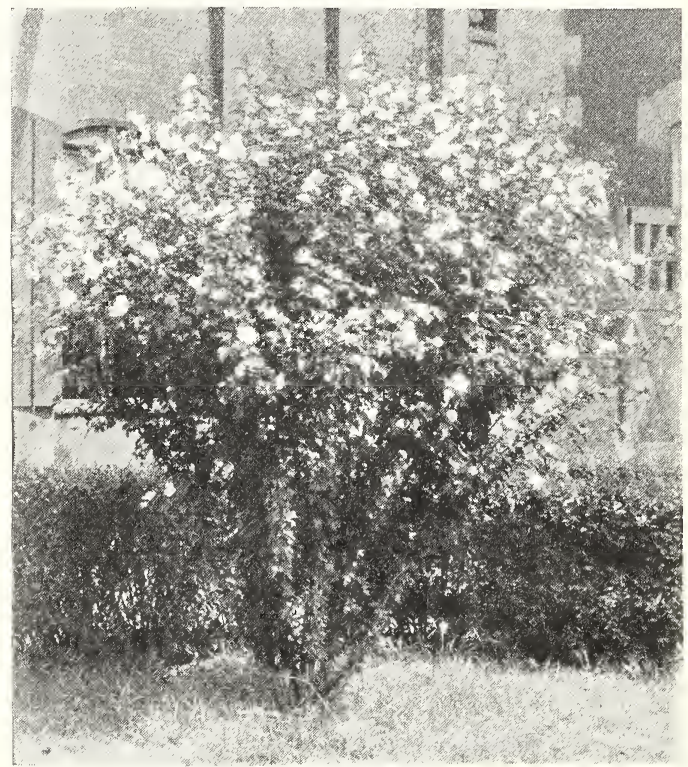

ROSE OF SHARON-Althea

LIGUSTRUM OVALIFOLIUM (California Privet)-One of the best hedge plants. Excellent habit. Persistent dark green, glossy foliage. $1-1 \frac{1}{2}$ ft., $100, \$ 4.00 ; 11 \frac{1}{2-2}$ ft., $100, \$ 6.00$

LILAC-The old-fashioned fragrant variety. Purple or white.

Each, $50 \mathrm{c}$

PHILADELPHUS CORONARIUS (Mock Orange)-A tall growing shrub. Flowers pure white and very fragrant. $2.3 \mathrm{ft}$., Each, 50c

PHILADELPHUS AUREA (Golden Syringa)Not so tall as the above. Attractive golden yellow foliage. 15-18 in., Each, 75c

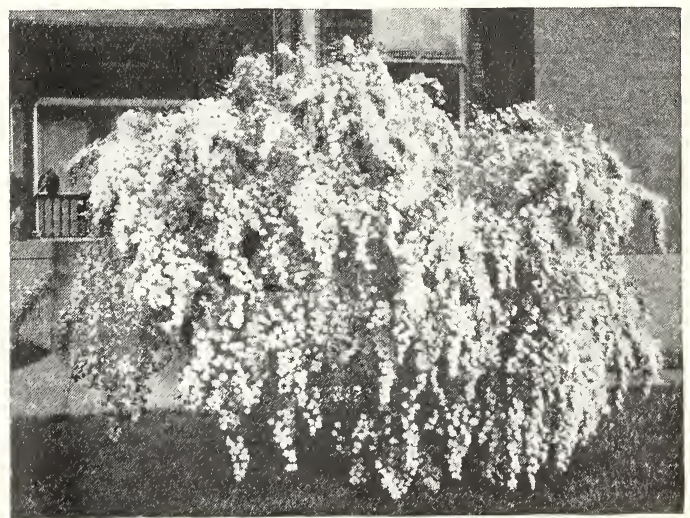

SPIREA VAN HOUTTEI 
S

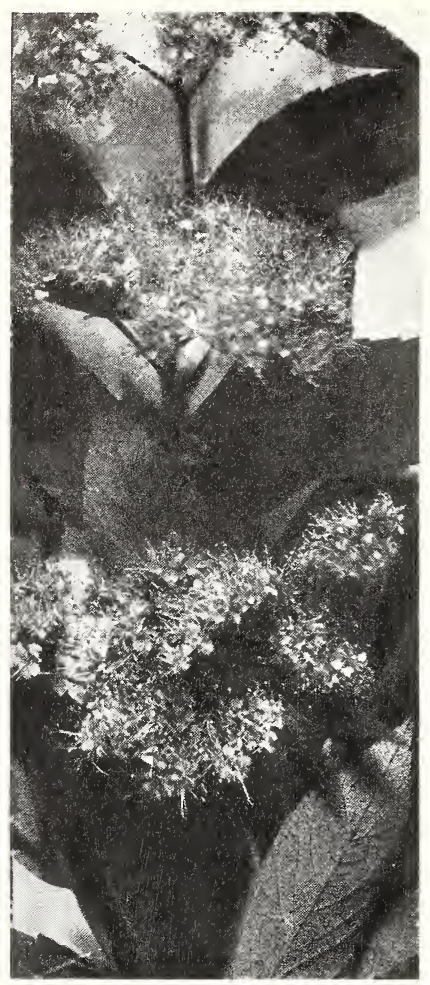
SPIREA ANTHONY WATERER

RHUS COTINUS (Smoke Tree or Purple Fringe) -Purple fringe-like blossoms resembling a cloud of smoke. Makes a very dignified and attractive specimen. $2.3 \mathrm{ft}$., Each, $\$ 1.50$

RHUS GLABRA LACINATA-Long, deeply cut leaves resembling ferns. Upright habit. 2-3 ft., Each, 75c

SPIREA ANTHONY WATERER-Bright crimson flowers. Rather dwarf.

11/2-2 ft., Each, 50c

SPIREA PRUNIFOLIA (Bridal Wreath) Double pure white flowers in profusion. One of the best flowering shrubs. 2-3 ft., Each, 50c

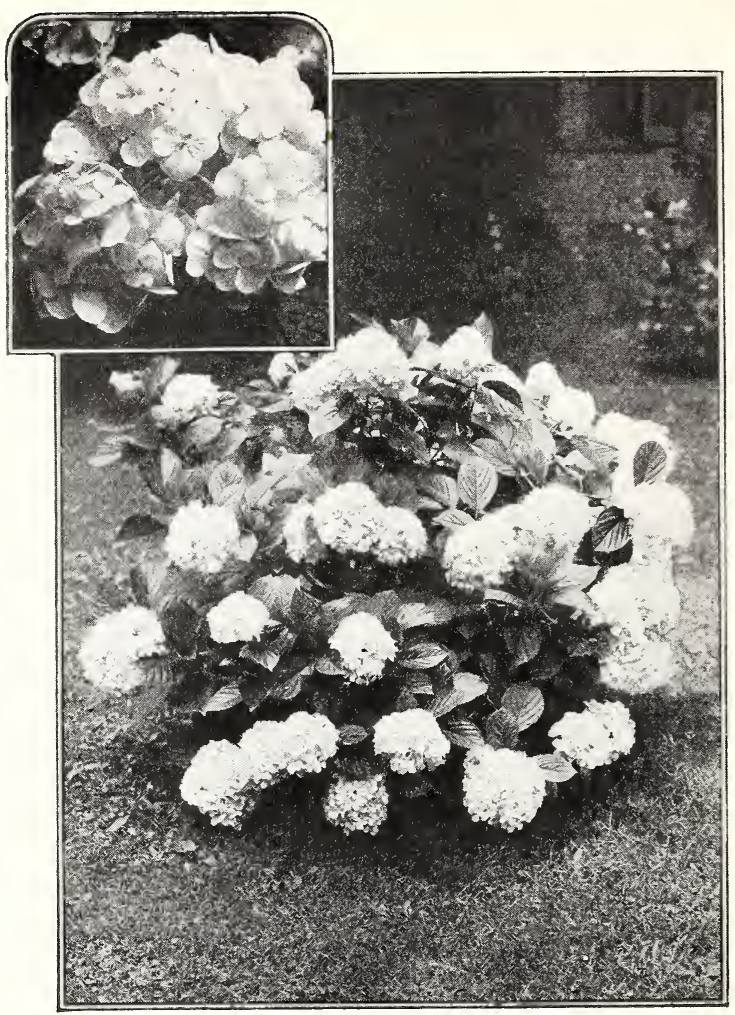

HYDRANGEA ARBORESCENS

Splendid for Shady Places. Blooms Aug.-Oct.

SPIREA VAN HOUTTEI - A graceful, strong shrub which completely covers itself with clus. ters of small white flowers in May.

$2-3$ ft., Each, 35c

VIBURNUM OPULUS (High Bush Cranberry)Clusters of white flowers in June, followed by clusters of glossy red berries which persist in the Winter. $2.3 \mathrm{ft}$., Each, 50c

VIBURNUM OPULUS STERILE ( $\mathrm{C}$ o $\mathrm{m} \mathrm{m}$ o $\mathrm{n}$ Snowball)-Globular clusters of white flowers in May. $2.3 \mathrm{ft}$., Each, 75c

VIBURNUM PLICATUM (Japan Snowball)White flowers in globular clusters. Attractive, deeply veined foliage. $\quad 2-3 \mathrm{ft}$., Each, $\$ 1.00$

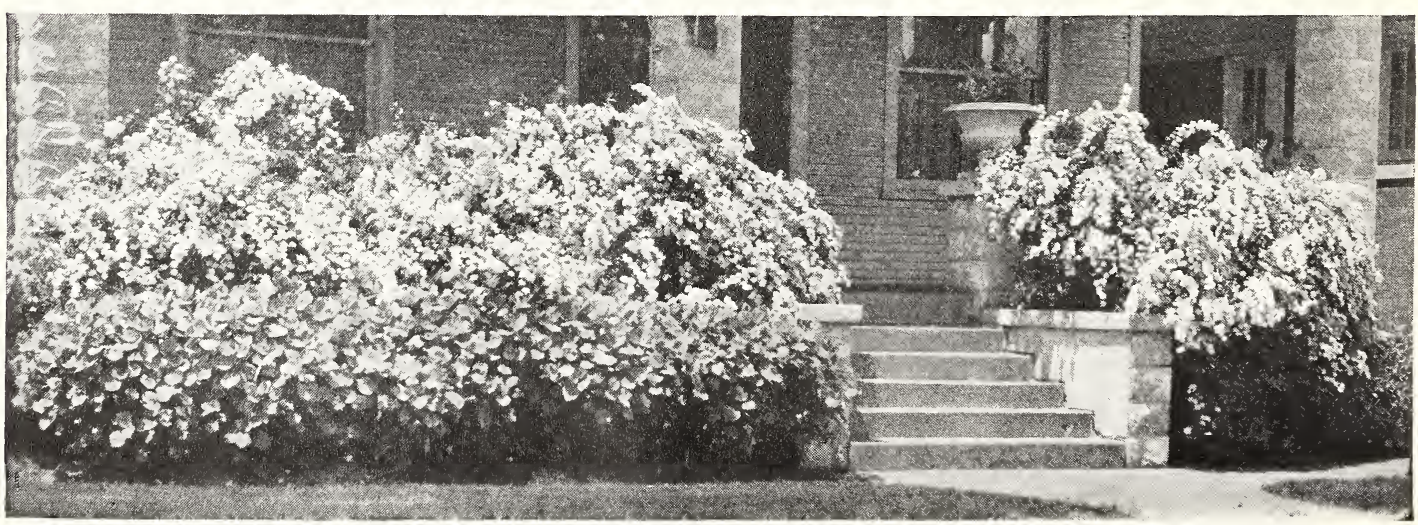

A FOUNDATION PLANTING OF SPIREA VAN HOUTTEI AND HYDRANGEA ARBORESCENS This Planting Can be Duplicated, Consisting of 15 Spirea Van Houttei and 15 Hydrangea Arborescens, for \$10.00. A Wonderfully Attractive Planting at a Low Cost. 


\section{Hardy Shrubs and Hedge Plants-Continued}

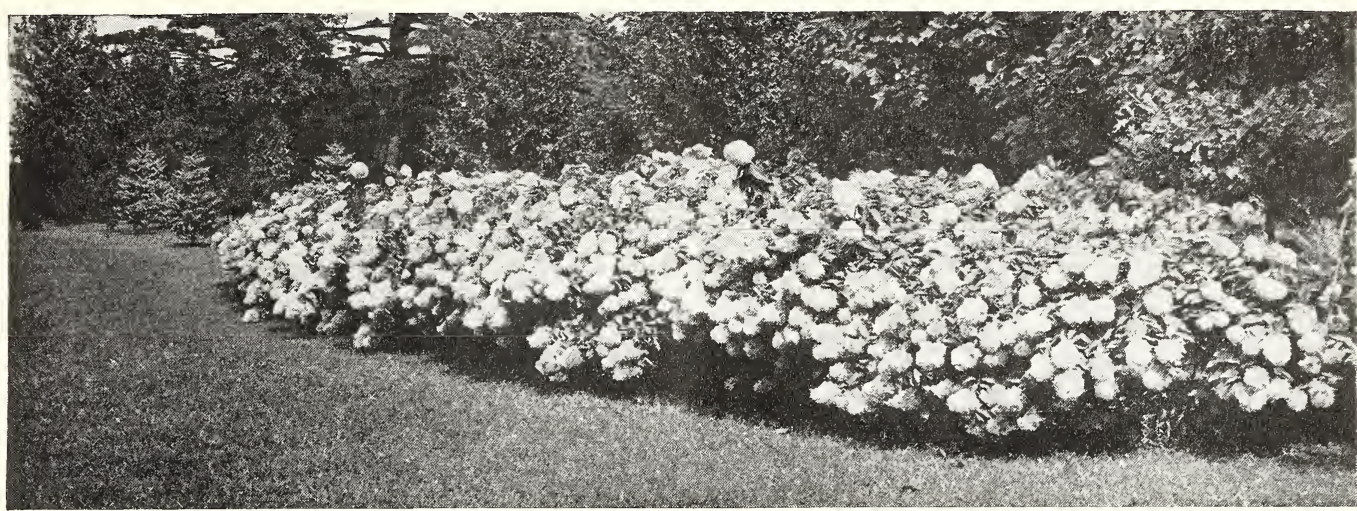

LUXURIANT BLOOM OF MASSED HYDRANGEAS WITH LEAFY BACKGROUND

WEIGELIA EVA RATHKE - Brilliant crimson flowers. Habit rather dwarf. Makes a very ornamental specimen.

$2.3 \mathrm{ft}$., Each, $\$ 1.00$

WEIGELIA ROSEA - Rose colored flowers in May. Taller than the above.

2.3 ft., Each, 50c

CYDONIA JAPONICA (Japanese Quince)-A dwarf shrub having attractive foliage and brilliant scarlet flowers in early Spring.

18-24 in., Each, 50c

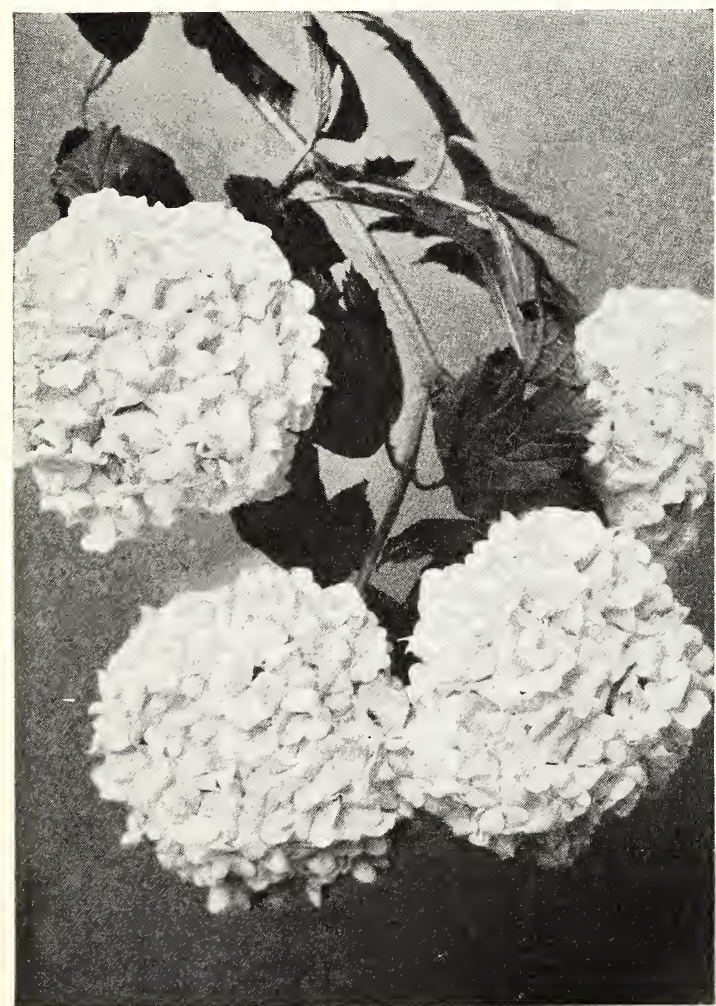

VIBURNUM OPULUS STERILE

Common Snowball
LONICERA FRAGRANTISSIMA ( $\mathrm{F}$ r a $\mathrm{g} \mathbf{r}$ a $\mathrm{n}$ t Honeysuckle)-Creamy white fragrant flowers in Spring. Retains its foliage until late Winter. 2.3 ft., Each, 75c

LONICERA MARROWI - A spreading shrub bearing white flowers in Spring, followed by attractive red fruits. $2.3 \mathrm{ft}$., Each, 50c

KERRIA JAPONICA fl. pl. (Yellow Globe Flower)-An attractive, upright shrub, large, double, bright yellow flowers in Spring.

2.3 ft., Each, 75c

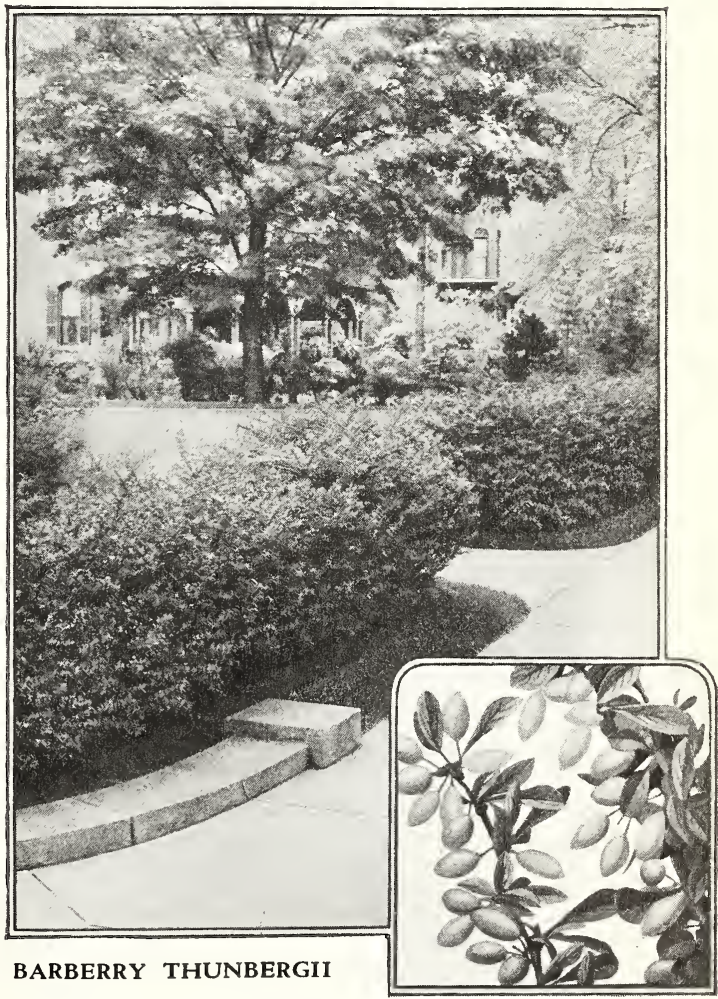

Makes a Lovely Informal, Low-growing Hedge. Extremety Hardy, Does Not Need Shearing 


\section{Beautiful and Popular Flowering Shrubs}

Every Home should have this Selected Collection, blooms from June to late Fall.

\section{Collection No. 291}

5 Colorful Shrubs

1 Hydrangea, $2-3 \mathrm{ft}$.

1 Deutzia Pride of Rochester, 2-3 ft.

1 Weigelia Rosea, 2-3 ft.

1 Syringa Mock Orange, 2-3 ft.

1 Viburnum Opulus

All for

$$
\$ 2.75
$$

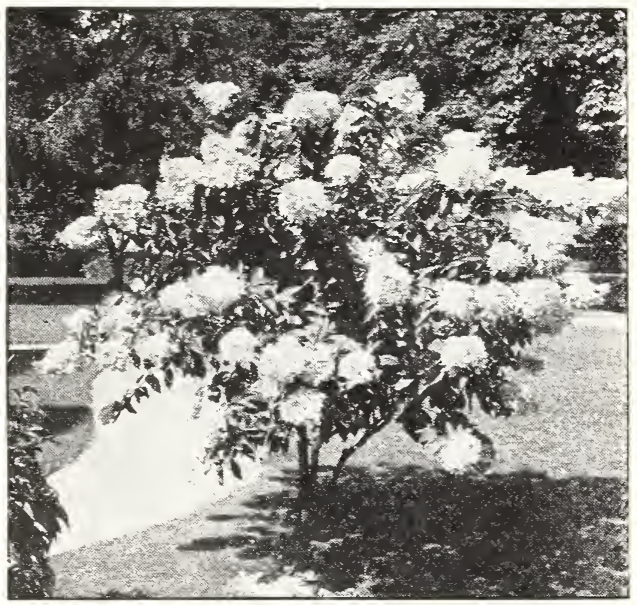

HARDY HYDRANGEA BUSH

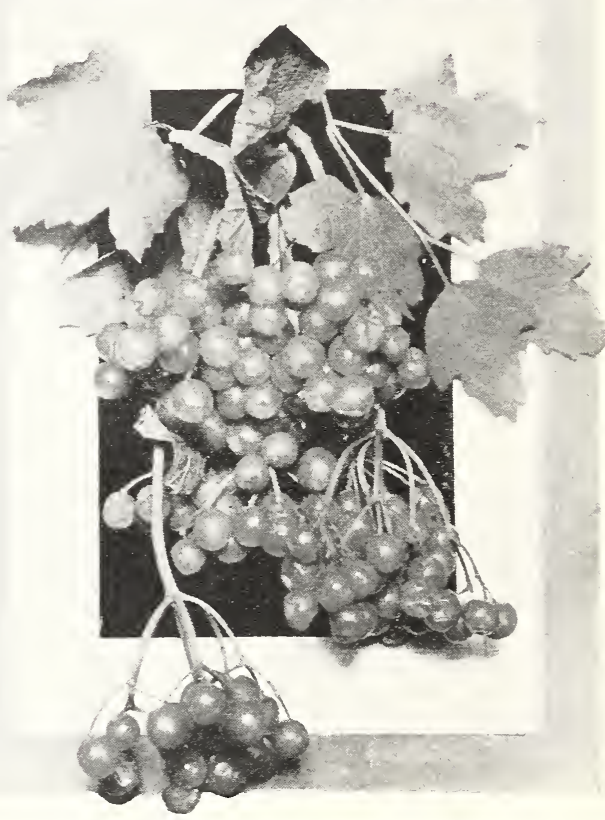

VIBURNUM OPULUS-Cranberry Bush

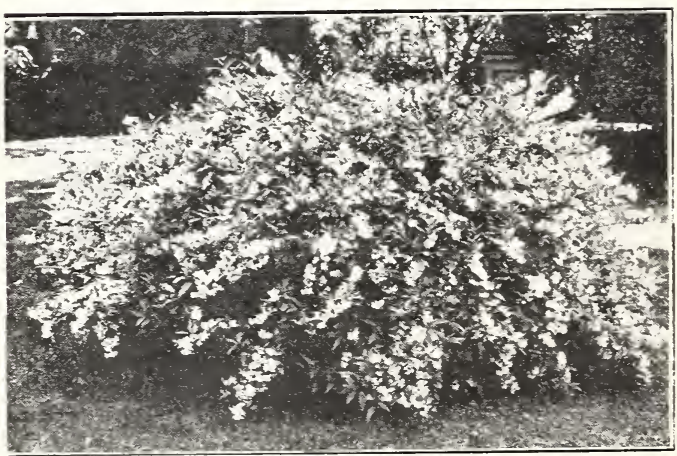

SYRINGA, MOCK ORANGE

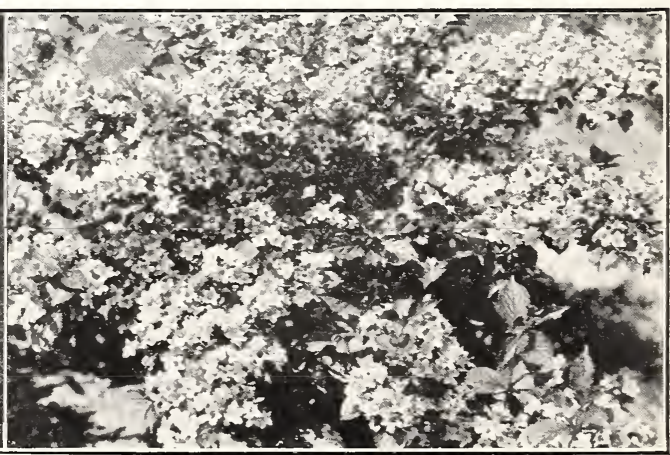

WEIGELIA ROSEA 


\section{CANNAS}

THESE are among the most attractive bedding plants in cultivation. They have large, attractive foliage varying in color from a clear deep green to a rich bronzy red. The modern varieties are not so tall as the older ones, but surpass them in size of bloom and brilliancy of coloring.

The roots should be placed in a box of moist moss or sand two or three weeks before planting out and kept in a warm place to start the sprouts and new roots. They should be planted about three inches deep and eighteen inches apart, with the taller varieties in the background. They flourish in rich soil and should be given plenty of moisture, and frequently hoed during the growing season. When the foliage has been killed by frost, it may be cut off and the roots dug and stored in a warm, dry place until the following Spring. The clumps should then be divided before replanting.

The following varieties are large flowering and have excellent foliage. We consider them the best in cultivation. We will gladly suggest varieties and tell you the number of plants required for your needs.

APRICOT -4 ft. Green foliage. Easy grower.

Rich apricot color.

CANARY BIRD $-31 / 2 \mathrm{ft}$. Green foliage. Canary yellow.

CUPID - 31/2 ft. Attractive green foliage. Flowers large, soft pink. Each, 35c

FLAG OF TRUCE- $4 \mathrm{ft}$. Green foliage. Creamy white. The best white.

FLORIDA-4 $1 / 2$ ft. Bronze foliage. Beautiful orange red. One of the best. Each, 35c

FLORENCE VAUGHN - 4 ft. Large green leaves. Blossoms large, yellow blotched red.

KING HUMBERT $-4 \mathrm{ft}$. Bronze foliage. Orange scarlet. Very popular.

KING MIDAS - $4 \mathrm{ft}$., Green foliage. The very best yellow canna.

Each, 50c

MRS. ALFRED CONARD-4 ft. Green foliage. Salmon pink. The best of this color.
MRS. WOODROW WILSON-31/2 ft. Green foliage. Large rose pink blossoms. Extra choice.

Each, 35c

STATUE OF LIBERTY- $61 / 2 \mathrm{ft}$. Massive bronze foliage. Orange scarlet. Very good.

SUSQUEHANNA-3 ft. Bronze foliage. Salmon. Very free.

THE PRESIDENT $-4 \mathrm{ft}$. Green foliage. The best red canna.

WINTZER'S COLOSSAL-4 ft. Green foliage. Bright scarlet. Very large.

YELLOW KING HUMBERT-4 ft. Green foliage. Yellow spotted. A very attractive variety. Except as noted, strong roots of any of the above Cannas, each, 25c; dozen, \$2.25. We will gladly quote special prices on large orders for bedding purposes.

\section{CANNAS SPECIAL}

A bed eight feet in diameter will require $16 \mathrm{dwarf}$ plants for the outer row and 8 taller ones for the center. For such a bed I would suggest 16 The President for the outer row and 8 Florida for the center; or 16 Mrs. Woodrow Wilson for the outer row, with 8 King Humbert for the center. We will send 24 roots, either collection, prepaid for $\$ 4.50$.

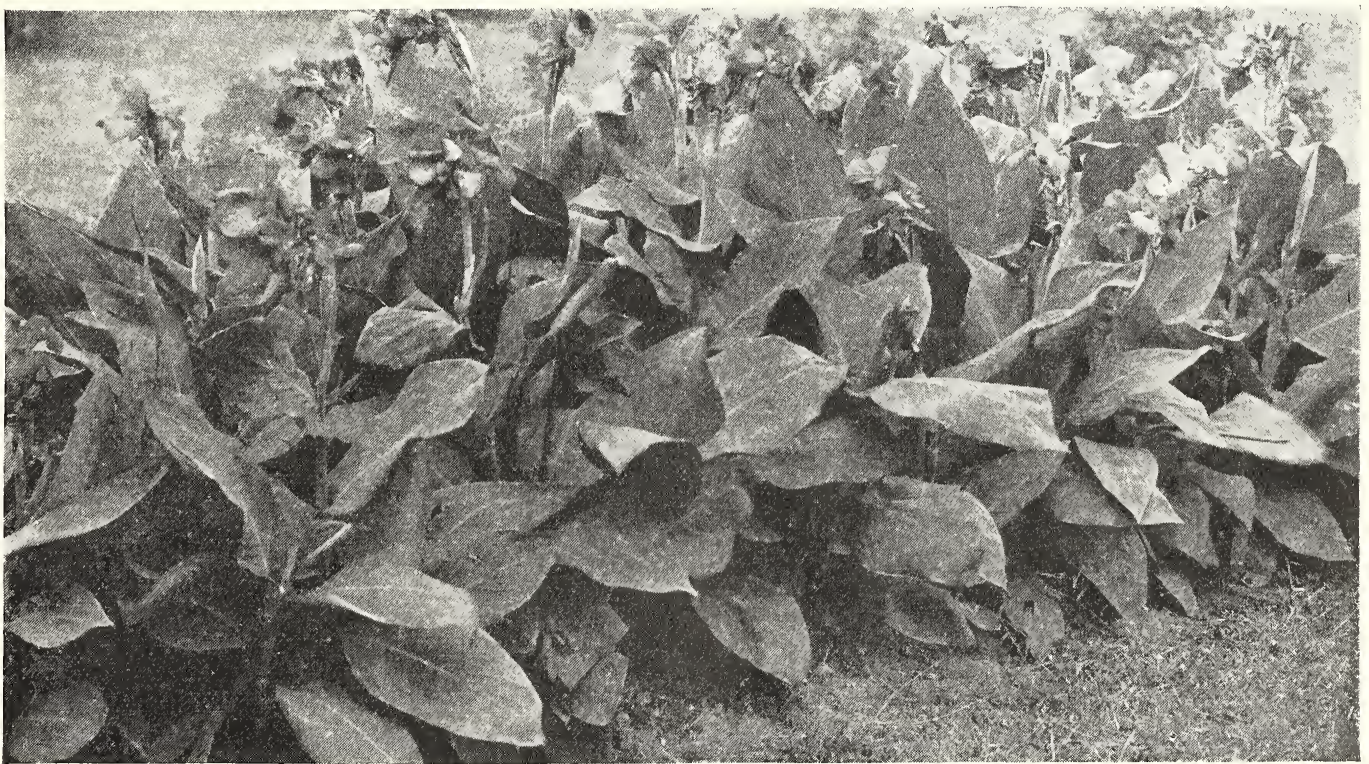

A Planting of Cannas in Bloom 


\section{EUROPEAN HYBRID FILBERTS}

A

$\mathrm{N}$ ornamental shrub having deep green, handsome foliage and producing abundant crops of delicious nuts. They withstand low temperatures and can be grown in practically all parts of the United States. Although they often bear nuts in the nursery row, heavy crops should not be expected until they are three or four years old.

A well drained soil, which need be only moderately rich, suits them best. Some of the medium sized varieties are of the highest quality and should be planted with the

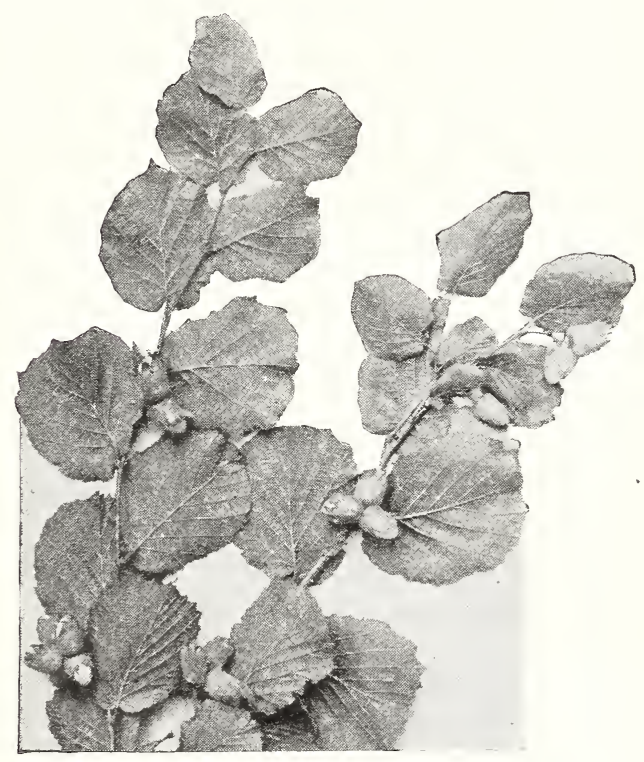

larger fruited varieties to insure better pollination.

The tops should be cut back when planting about one-half and the suckers inclined to appear from the roots the first year or two should be dug out and cut off close to the root. The new growth should be cut back about one-half each spring and the center trimmed out to insure ventilation. They form low trees about 12 feet high and should be planted from eight to twelve feet apart.

Fertilizers should be used sparingly except where the ground is poor and stony, as on too rich soil they are apt to grow too vigorously and will require more severe pruning.

We have only a few large plants to offer this year in collections of six varieties, one of each for $\$ 9.00$, by express.

\section{ENGLISH FILBERTS}

This illustration shows fifteen Filberts (Hazel Nuts) growing on a branch of a young Filbert tree two years after transplanting. As an ornamental tree around the home grounds, planted along the driveway or grown commercially, these interesting nut bearing trees are practically new in this country, but grown extensively in Europe. Don't fail to plant this novelty.

\section{LANDSCAPE PLANTING}

Every home, in the city or country, vastly improves in appearance and value through intelligent landscaping. The pleasure of looking upon a well kept lawn, dotted with trees and colorful shrubs, with the house nestling among bright, cheerful flowers and green foliage, is immeasurable. We have a complete line of ornamental trees, shrubs and plants which we have been unable to describe in our limited space, but we will be glad to make recommendations for landscaping the home grounds or in developing plans for formal gardens, rockeries, water gardens and other spots of beauty.

A bit of time and money judiciously spent will return a hundred fold in pleasure and satisfaction as the planting grows in richness and beauty as the years roll by. 


\section{ORDER BLANK}

\section{N. A. Hallauer, Webster, N.Y.}

Gentlemen: Please send me the Nursery Stock as listed herewith, for which I enclose a money order or. for $\$$

(If a married woman, write "Mrs." and husband's first name and mid-

\begin{tabular}{|c|c|c|c|c|}
\hline $\begin{array}{l}\text { WRITE } \\
\text { YOUR } \\
\text { NAME } \\
\text { HERE }\end{array}$ & $\begin{array}{l}\text { Mrs., Miss } \\
\text { or } \mathrm{Mr} \text {. }\end{array}$ & FIRST NAME & $\begin{array}{c}\text { Middle } \\
\text { Initial }\end{array}$ & LAST NAME \\
\hline
\end{tabular}

Street Number or R. F. D .

Post Office

Send by $\quad\left\{\begin{array}{l}\text { Express Office } \\ \text { Express Co. } \ldots\end{array}\right.$

Freight Station

PRICES IN THIS CATALOG SUPERSEDE THOSE OF ALL FORMER EDITIONS

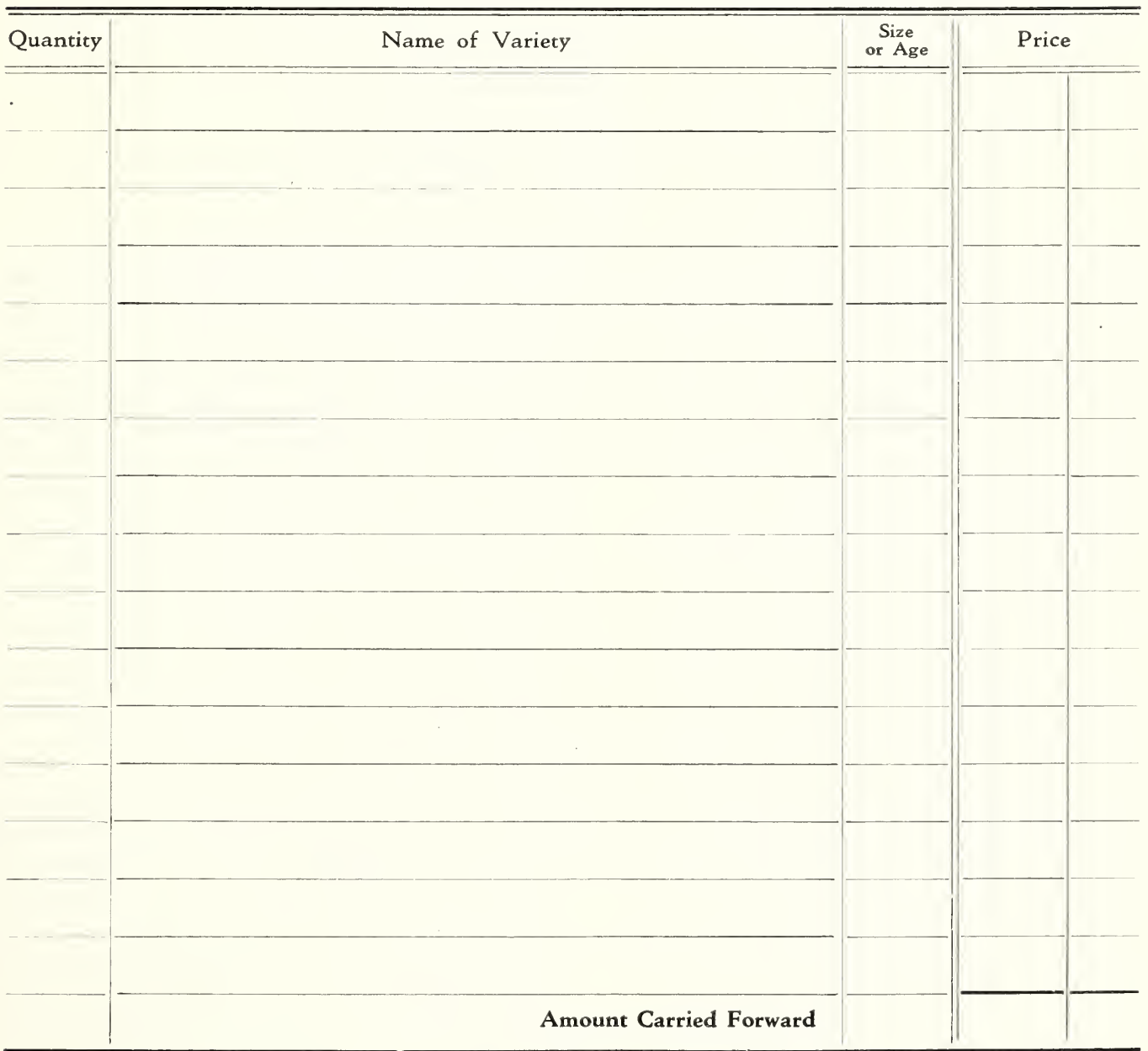




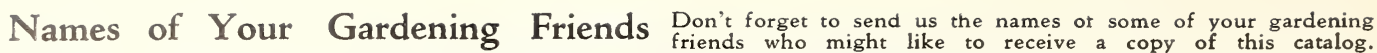
Space on the back of this order blank is provided for that purpose. Your friends will appreciate this and it will help us to enlarge our list of prospective customers.

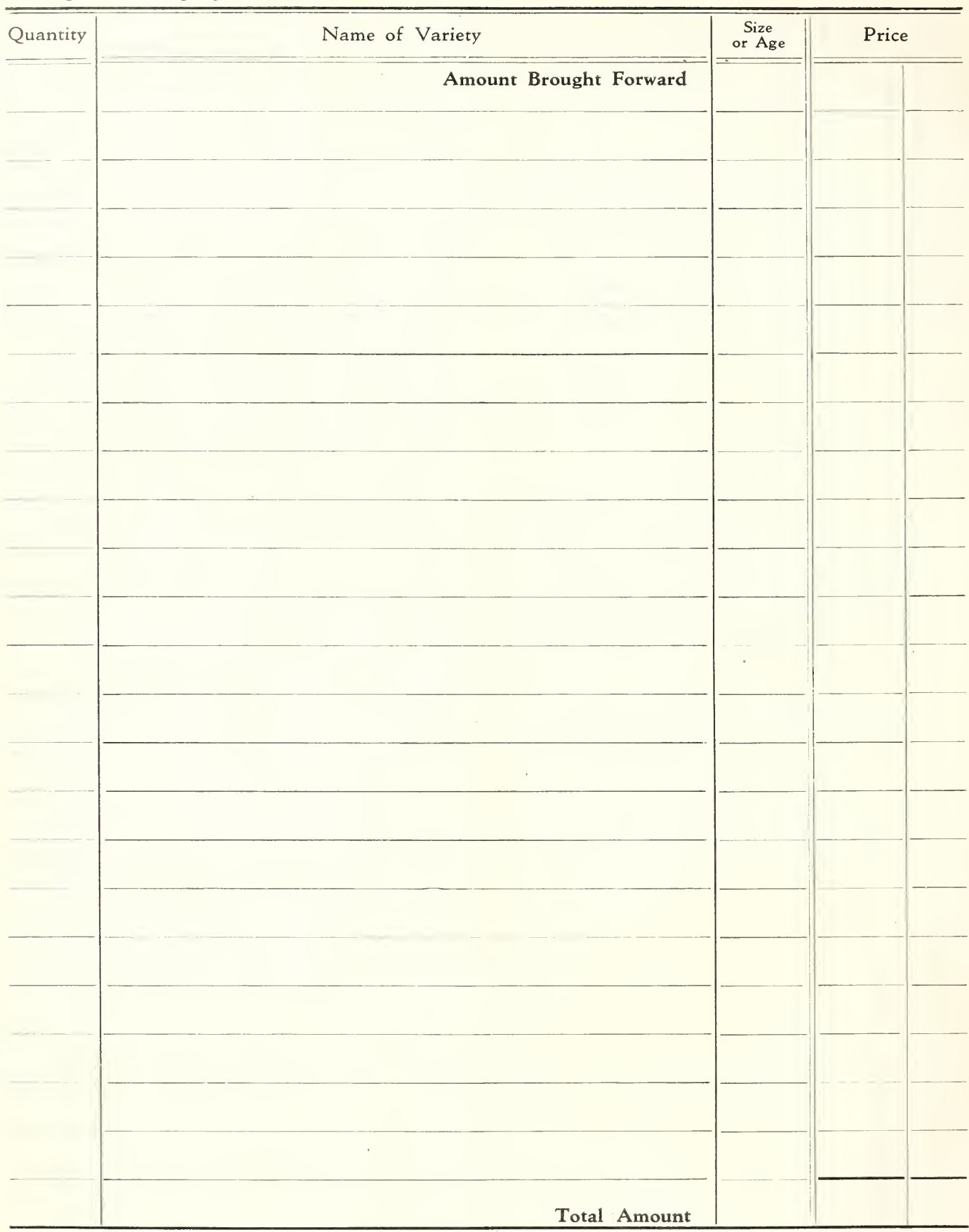

Any Friends of Yours who you know would like to receive a copy of our catalog, from which to order, names and addresses below. nes and addresses below.

\begin{tabular}{c|c|c|c}
\hline Names & Street or R. F. D. & Sost Office & \\
\hline & & & \\
\hline
\end{tabular}




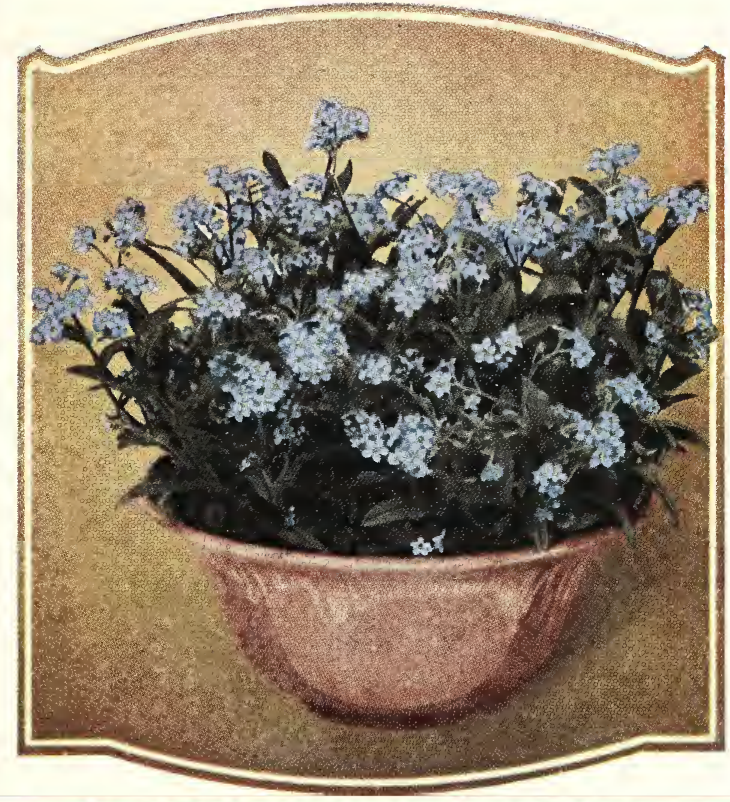

FORGET-ME-NOT-Myosotis palustris, Each, 25c

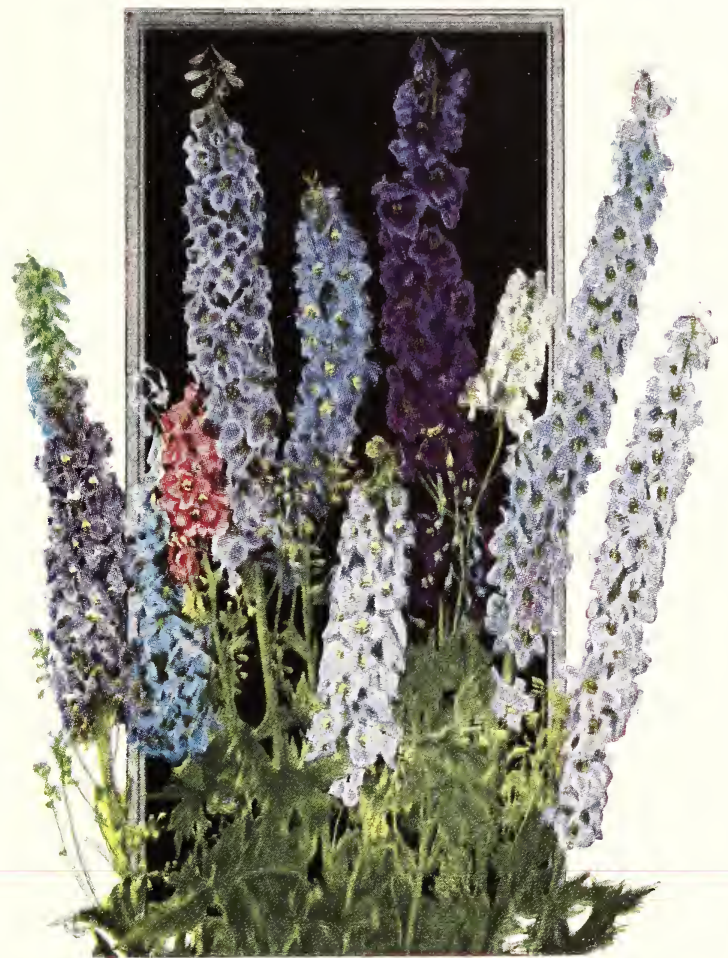

DELPHINIUM-French Hybrids, Each, 50c

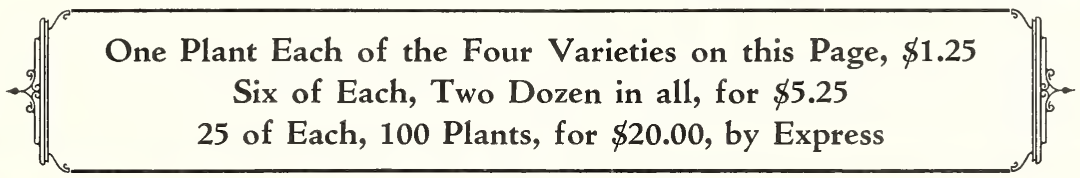

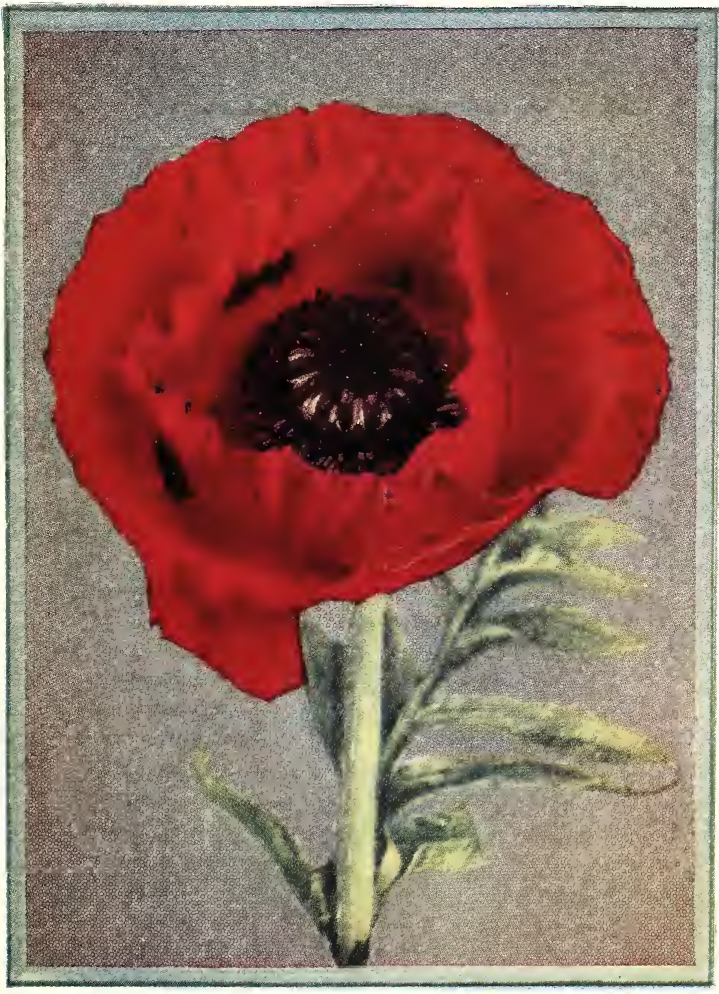

PAPAVER ORIENTALE-Oriental Poppies, Each, 35c Mixed hybrids. Scarlet shades. Large and showy.

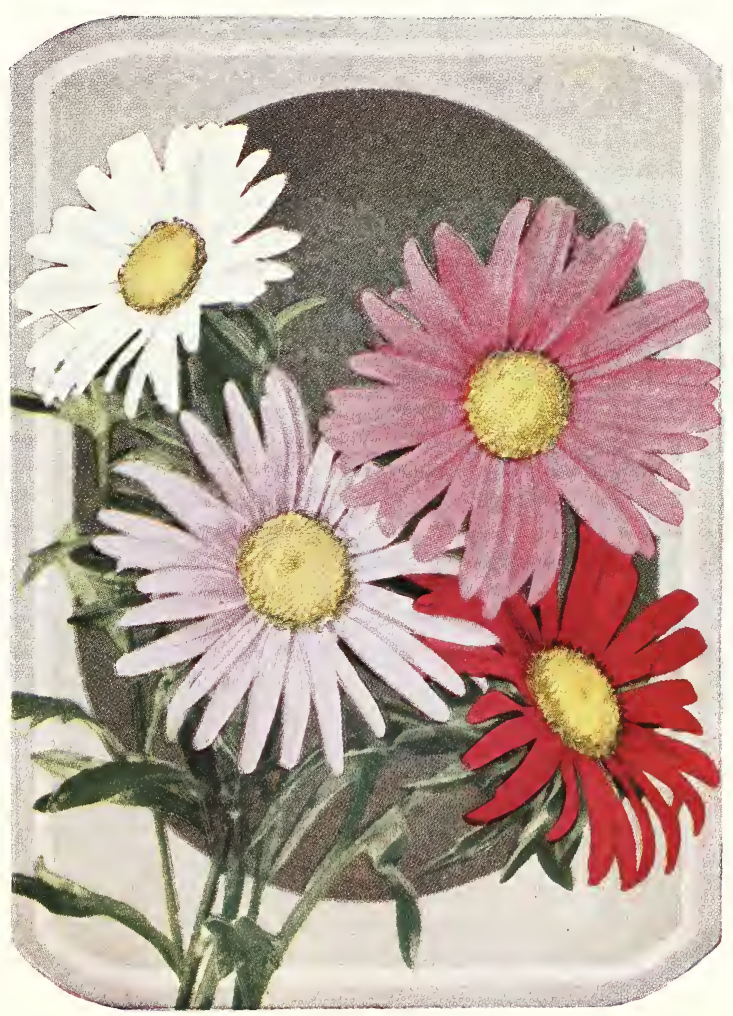

PYRETHRUM ROSEUM, Each, 25c 


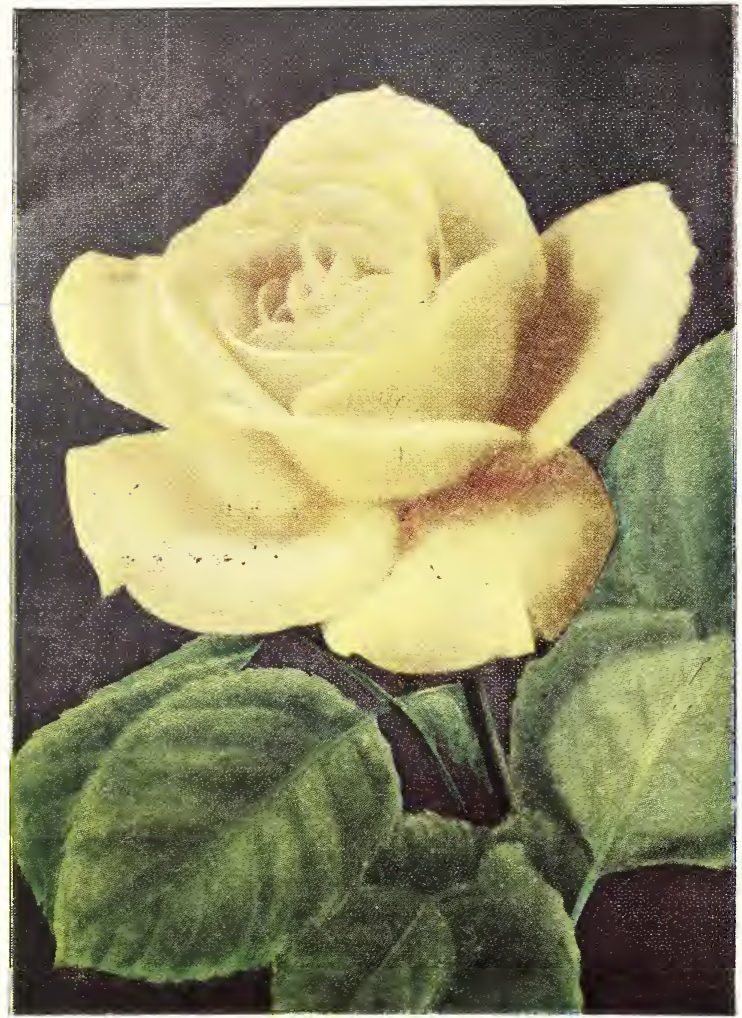

SOUV. DE CLAUD. PERNET, Each, $\$ 1.50$

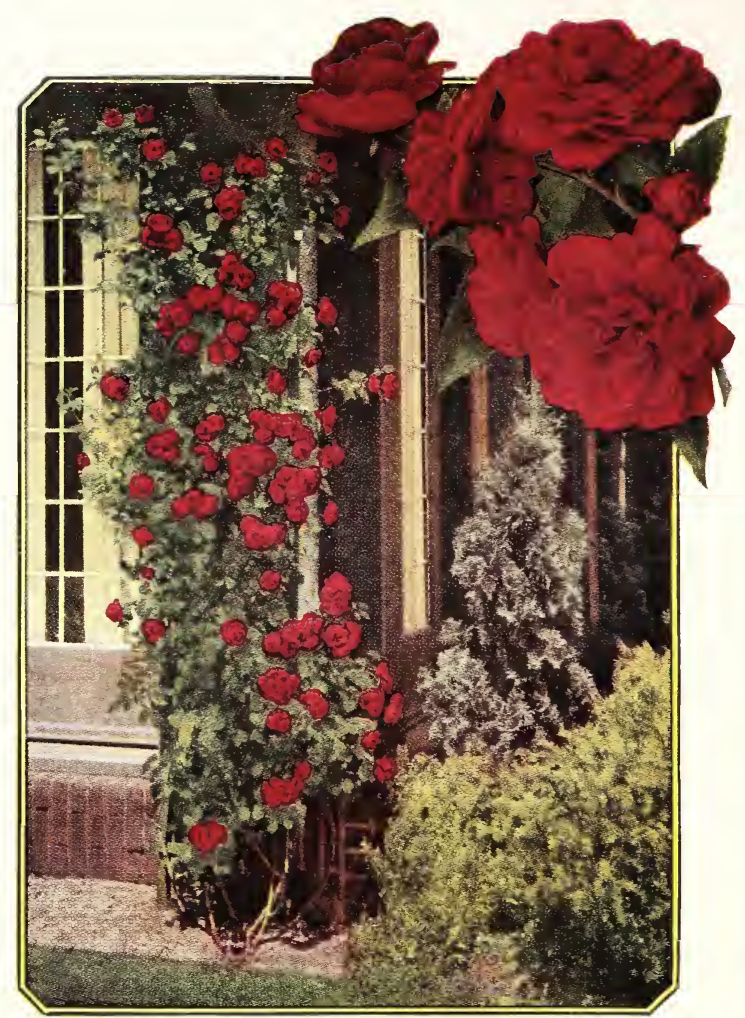

PAUL'S SCARLET CLIMBER, Each, 75c

\section{SPECIAL ROSE COLLECTION}

Strong, hardy, 2 year old, field grown roses

Collection of $4, \$ 3.75$

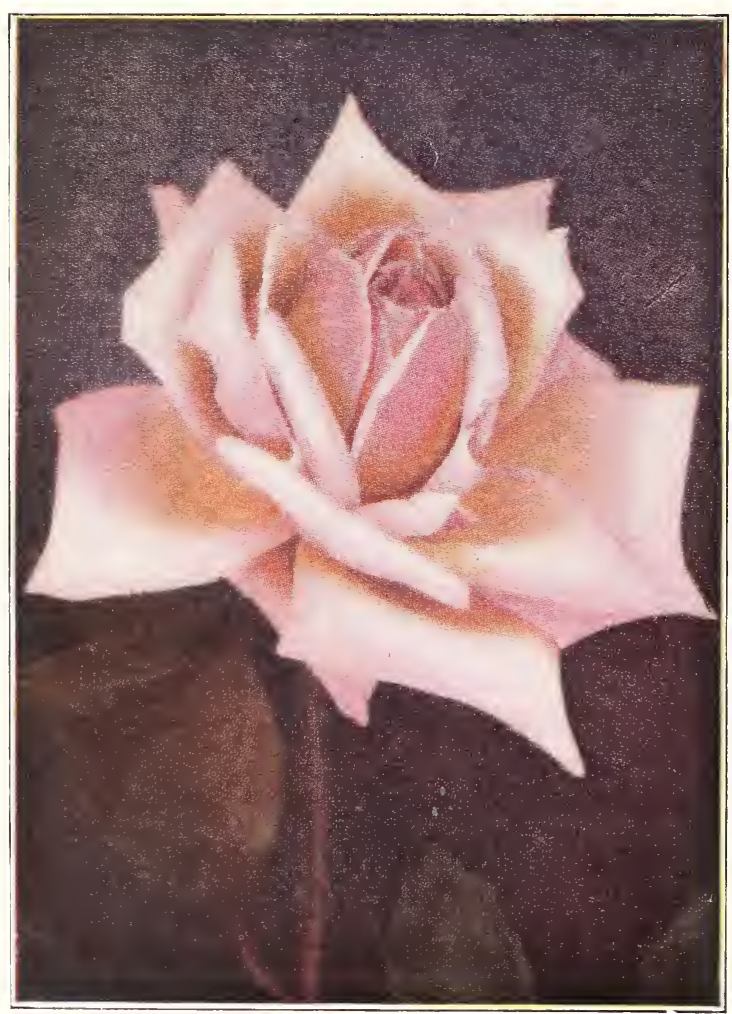

LOS ANGELES, Each, $\$ 1.00$
Collection of $8, \$ 7.25$

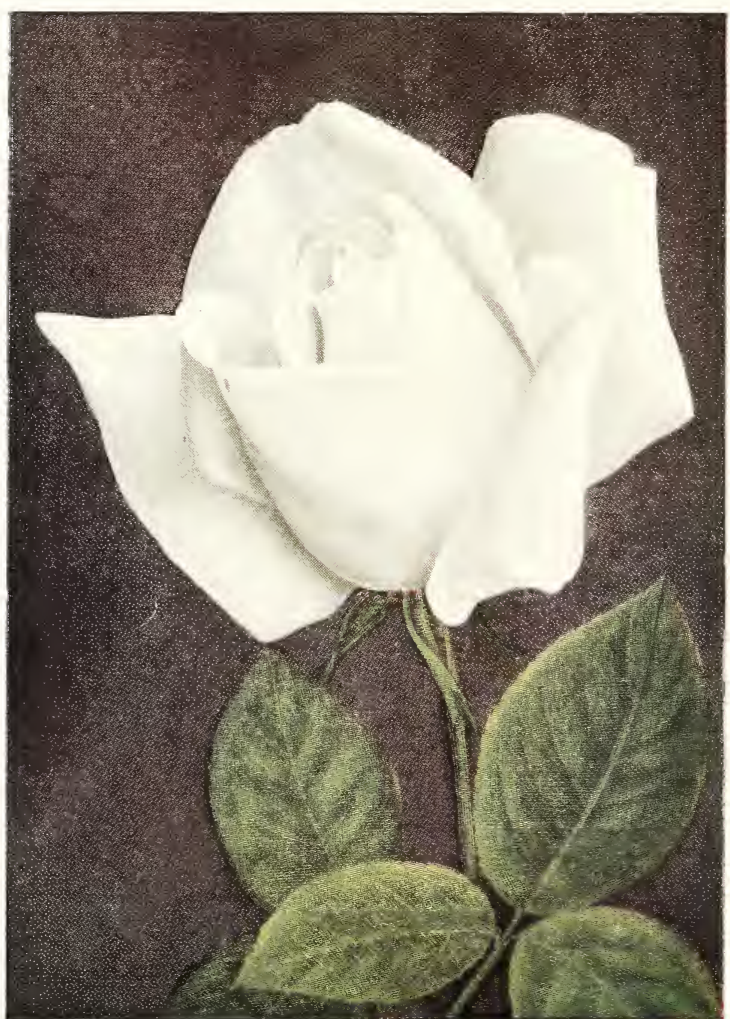

FRAU KARL DRUSCHKI, Each, 75c 